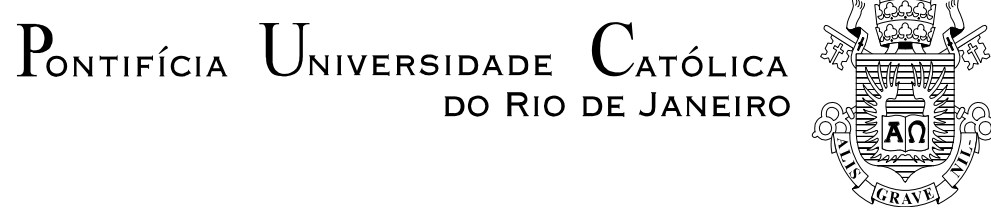

Silvia Follain de Figueiredo Lins

\title{
A ascensão do STF e os limites do poder: Teoria e prática na narrativa constitucional contemporânea
}

Dissertação de Mestrado

Dissertação apresentada como requisito parcial para obtenção do grau de Mestre pelo Programa de Pósgraduação em Direito do Departamento de Direito da PUC-Rio.

Orientador: Prof. Fábio Carvalho Leite

Rio de Janeiro

Junho de 2017 


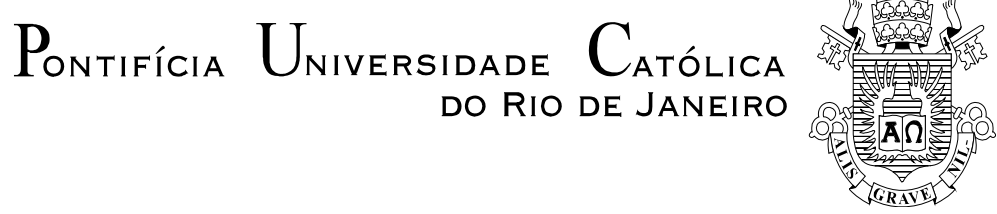

Silvia Follain de Figueiredo Lins

\begin{abstract}
A ascensão do STF e os limites do poder:
Teoria e prática na narrativa constitucional contemporânea
\end{abstract}

Dissertação apresentada como requisito parcial para obtenção do grau de Mestre pelo Programa de Pósgraduação em Direito do Departamento de Direito do Centro de Ciências Sociais da PUC-Rio. Aprovada pela Comissão Examinadora abaixo assinada.

\author{
Prof. Fábio Carvalho Leite \\ Orientador \\ Departamento de Direito - PUC-Rio
}

Prof. José Ribas Vieira

Departamento de Direito - PUC-Rio

Prof. Diego Werneck Arguelhes

Escola de Direito - Fundação Getúlio Vargas

Profa. Augusto César Pinheiro da Silva

Vice-Decano Setorial de Pós-Graduação do

Centro de Ciências Sociais da PUC-Rio

Rio de Janeiro, 27 de junho de 2017 
Todos os direitos reservados. É proibida a reprodução total ou parcial do trabalho sem autorização da universidade, do autor e do orientador.

\section{Silvia Follain de Figueiredo Lins}

Graduada em Direito pela Universidade do Estado do Rio de Janeiro (2003). Candidata ao título de mestre em Direito pela Pontifícia Universidade Católica do Rio de Janeiro. Tem como principal área de interesse a jurisdição constitucional e sua relação com a política.

Ficha Catalográfica

Lins, Silvia Follain de Figueiredo.

A ascensão do STF e os limites do poder : teoria e prática na narrativa constitucional contemporânea / Silvia Follain de Figueiredo Lins ; orientador: Fábio Carvalho Leite. 2017.

160 f. ; $30 \mathrm{~cm}$

Dissertação (mestrado)-Pontifícia Universidade Católica do Rio de Janeiro, Departamento de Direito, 2017.

Inclui Referências bibliográficas

1. Direito - Teses. 2. Supremo Tribunal Federal. 3. Jurisdição constitucional. 4. Judicialização da política. 5. Ativismo judicial. 6. Legitimidade democrática. I. Leite, Fábio Carvalho. II. Pontifícia Universidade Católica do Rio de Janeiro. Departamento de Direito. III. Título. 
A Luiz Henrique, minha fonte diária de força e doçura, e a Vinícius, sujeitinho sorridente, que chegou para tornar a vida mais leve. 


\section{Agradecimentos}

Agradeço ao Luiz Flávio, por acumular tão bem as funções de marido, pai, melhor amigo e parceiro de projetos. Sem você ao meu lado, a vida não teria graça. Obrigada por reservar para mim a sua versão mais doce e seu olhar mais generoso.

À minha mãe, fonte de amor infinito, por cada luta e cada percalço assumidos na trajetória árdua da maternidade. Obrigada por me ensinar a ver o mundo através de sua perspectiva inconformada e a senti-lo a partir de seu coração gigante. Sua entrega à minha causa foi o que sempre me permitiu "a arte de sorrir quando o mundo diz não”.

Ao Cláudio, que, no dicionário da minha vida, define, muito além das palavras, todo amor, carinho e compreensão paternos.

À Carol e à Raquel, que ressignificam, cotidianamente, o conceito de amizade.

Ao meu orientador Fábio Leite, pelo enorme cuidado e atenção dedicados a este projeto. Este trabalho é fruto de suas observações precisas, de seu olhar desafiador, de sua crítica sempre inteligente e, por que não dizer, de seu senso de humor afiado, que tornou o processo - sempre sofrido - de elaboração da dissertação muito mais agradável.

Um agradecimento mais que especial a Luiz Eduardo Melin, que, de forma gentilíssima, dispendeu tempo e energia para ajudar a definir os rumos desta pesquisa. Foi um privilégio poder contar com sua imensa cultura geral, com suas opiniões perspicazes e com suas análises políticas invariavelmente perfeitas. 
Ao Anderson e à Carmen, essenciais na vida de qualquer mestrando e doutorando. Muito obrigada por tudo!

Por fim, aos amigos da turma Amor y Juego, figurinhas incrivelmente acolhedoras, divertidas e solidárias, que tornaram minha experiência no mestrado muito mais alegre e memorável. 


\section{Resumo}

Lins, Silvia Follain de Figueiredo; Leite, Fábio Carvalho. A ascensão do STF e os limites do poder: teoria e prática na narrativa constitucional contemporânea. Rio de janeiro, 2017. 160p. Dissertação de Mestrado Departamento de Direito, Pontifícia Universidade Católica do Rio de Janeiro.

A centralidade assumida pelo STF na cena política brasileira tem suscitado diversas reflexões teóricas sobre o papel a ser exercido pela jurisdição constitucional e sobre sua legitimidade democrática. No âmbito latino-americano, muito tem se falado em um novo constitucionalismo caracterizado, dentre outros aspectos, pela ampliação da gama de direitos previstos e pelo fortalecimento do Judiciário. O presente trabalho tem por objetivo discutir a atuação do Supremo Tribunal Federal em face das perspectivas criadas pelas teorias que buscam justificar seu protagonismo. Para tanto, parte-se da premissa de que a análise crítica do fenômeno deve contemplar não apenas os elementos jurídicos, mas também a natureza política de muitas das escolhas realizadas pela corte e por seus membros. Nessa linha, são trazidos alguns julgamentos históricos do tribunal, escolhidos para demonstrar como ele construiu seu personagem ao longo do tempo, dando destaque tanto para as dimensões políticas como jurídicas de sua atuação. Em seguida, discutem-se as possibilidades de desenhos institucionais em países marcados por fortes desigualdades sociais, dentro de um contexto de entusiasmo com o desempenho das cortes constitucionais na efetivação de garantias básicas da cidadania. Após este panorama teórico, o trabalho se debruça sobre a realidade empírica da atuação do tribunal, verificando em que medida sua conduta corresponde às expectativas criadas em torno das capacidades institucionais da jurisdição constitucional.

\section{Palavras-chave}

Supremo Tribunal Federal; Jurisdição Constitucional; Judicialização da Política; Ativismo Judicial; Legitimidade Democrática. 


\section{Abstract}

Lins, Silvia Follain de Figueiredo, Leite, Fábio Carvalho (Advisor). STF's ascension and the boundaries of power: theory and practice in the contemporary constitucional narrative. Rio de janeiro, 2017. 160p. Dissertação de Mestrado - Departamento de Direito, Pontifícia Universidade Católica do Rio de Janeiro.

The central role assumed by the Federal Supreme Court in the Brazilian political scene has raised various theoretical considerations about the part that the constitutional jurisdiction will play, and about its democratic legitimacy. In the Latin-American context, a lot has been said about a new constitutionalism, which is characterized, among other aspects, by a greater scope of prescribed rights and by the strengthening of the judiciary. The present work intends to discuss the Federal Supreme Court's practice, taking in consideration perspectives created by theories that seek to justify its protagonism. For this purpose, this work assumes that the critical analysis of the phenomenon must contemplate not only legal elements, but also the political nature of many of the choices made by the Court and its members. Therefore, historical judgments of the Court were selected to demonstrate how it has built its persona through time, highlighting both the political and legal dimensions of its action. After that, this work will discuss institutional designs possibilities in countries characterized by strong social inequalities, inside a context of social excitement about the performance of constitutional courts in implementing basic citizenship guarantees. After the theoretical overview, the research approaches the empirical reality of Court practices, verifying to what extent its conducts correspond to the expectations created around the institutional abilities of constitutional jurisdiction.

\section{Keywords}

Brazilian Supreme Court; Judicial Review; Judicialization of politics; Judicial Ativism; Democratic legitimacy. 


\section{Sumário}

1 Introdução

2 De leões de pé de trono a vanguarda iluminista: o STF e a $\begin{array}{ll}\text { construção de seu personagem político } & 15\end{array}$

2.1. Sobre ativismo, judicialização da política e protagonismo do STF 15

2.2. A construção do personagem político ao longo da história 24

2.2.1. Início republicano 25

2.2.2. A Revolução de 1930 e o Estado Novo 41

2.2.3. A Constituição de 1946 e a instabilidade política das décadas de 1950/1960 48

2.2.4. Ditadura Civil-Militar de 1964

2.3. Conclusões 69

3 O STF e a política a partir da Constituição Federal de 1988

3.1. O novo constitucionalismo latino-americano e as razões de entusiasmo com a intervenção das cortes constitucionais 71

3.2. Qual o papel do STF no pós-1988? 82

4 Parâmetros para a crítica da atuação do STF $\quad 97$

4.1. Grau de neutralidade em relação às forças políticas 97

4.2. Qualidade da fundamentação das decisões 111

4.3. Quantidade de recursos políticos à disposição 135

5 Considerações finais 144

6 Referências bibliográficas $\quad 147$ 


\section{1 Introdução}

A importância assumida pelo Poder Judiciário como ator político tem suscitado uma série de estudos acadêmicos, muitos deles dedicados a entender o protagonismo do Supremo Tribunal Federal no cenário institucional brasileiro contemporâneo ${ }^{1}$. Afinal, onde reside sua legitimidade para interferir tão incisivamente na realidade política? Como avaliar sua atuação? É ativista ou acovardado? Tirano ou garantidor da democracia? Técnico ou político? Dono da última palavra ou interlocutor de diálogos institucionais?

O presente trabalho tem por objetivo discutir a atuação deste tribunal à luz das teorias que buscam legitimar a jurisdição constitucional e em face do entusiasmo que o papel das cortes constitucionais tem despertado no âmbito da história latino-americana recente. O ponto de partida escolhido foi a dimensão política das opções, práticas e recursos que o tribunal dispõe ao exercer suas funções.

Esta abordagem pode parecer trivial, já que, atualmente, é muito difícil encontrar quem sustente um real insulamento do direito em relação à política²

\footnotetext{
${ }^{1}$ Para um panorama das diversas chaves interpretativas que buscam explicar a transformação do Supremo de coadjuvante em protagonista, ver: ARGUELLES, Diego Werneck; RIBEIRO, Leandro Molhano. Criador e/ou Criatura: transformações do Supremo Tribunal Federal sob a Constituição de 1988. Revista Direito GV, v. 12, mai-ago 2016.

2 Andrei Koerner ilustra bem a ideia das imbricações entre direito e política na atividade jurisdicional: "Por exemplo, a questão do federalismo, que é uma dimensão estrutural do Estado. Um jurista pode ser mais federalista, ou, pelo contrário, unitarista e ter uma série de argumentos jurídicos, mas necessariamente haverá uma dimensão política, em termos da relação com as circunstâncias, o processo e as implicações de se adotar uma outra posição e de escolher certos argumentos e não outros para defendê-la. Então, nesse sentido, os juristas fazem política o tempo todo.” (2013, p.30) Alexandre Veronese, contudo, discorda desta concepção: "Uma crítica à perspectiva de Koerner pode ser feita a partir da indicação de que ele reduziu conceitualmente as decisões judiciárias ao mesmo patamar das decisões políticas. (...) No início do presente artigo, o problema contemporâneo da teoria do direito foi indicado de forma sucinta e clara. Ele está fortemente relacionado à possibilidade de construção de um método interpretativo - razoavelmente parametrizado e socialmente aceito - que sirva de fixação de referenciais para as ações sociais em uma seara diferenciada funcionalmente. Ademais, tendo por base o que é percebido socialmente como 'direito'. Tal construção precisa de uma relativa autonomia, portanto, das decisões políticas. Isto desemboca no dilema político de uma legitimidade específica do direito em relação à política, o que é um tema clássico do constitucionalismo moderno. Se a pista de Koerner for seguida, o sistema judiciário será entendido como parte do sistema político sem funcionalidade específica.
} 
Nas palavras de Conrado Hübner Mendes, a ciência política é responsável por denunciar que o rei está nu: “o juiz constitucional é um ator político que reage conforme variáveis outras que não somente a norma, a razão, ou as recomendações que a teoria normativa lhe endereça” (2008b, p.200).

Entretanto, a opção realizada se justifica, fundamentalmente, por duas razões. A primeira delas é que a teoria que defende o protagonismo da jurisdição constitucional o faz valorizando as capacidades institucionais da corte em detrimento do desempenho do Executivo e do Legislativo. O tema da legitimidade da jurisdição constitucional é comumente introduzido por um preâmbulo que trata da crise da nossa democracia representativa e das distorções de nosso sistema político-eleitoral $^{3}$ (NETO \& SARMENTO, 2015). Há, assim, uma inevitável comparação entre o direito, visto como instância da técnica, da estabilidade, onde a legalidade se assenta em si mesma, e a instância da política, concebida como arena da vontade, “dos interesses mesquinhos inconfessáveis, da vulgaridade, ilustrado pelo espetáculo deprimente dos escândalos, da corrupção e da violência que vê na mídia” (KOERNER, 2013, p.24). Neste contexto, Luís Roberto Barroso (2015) chegou a afirmar:

Em curioso paradoxo, o fato é que em muitas situações juízes e tribunais se tornaram mais representativos dos anseios e demandas sociais do que as instâncias políticas tradicionais. É estranho, mas vivemos uma quadra em que a sociedade se identifica mais com seus juízes do que com seus parlamentares. Um exemplo ilustra bem a afirmação: quando o Congresso Nacional aprovou as pesquisas com células-tronco embrionárias, o tema passou despercebido. Quando a lei foi questionada no STF, assistiu-se um debate nacional (BARROSO, 2015, p.23).

Assim, diminuirá ou poderá haver desaparecimento dessa tarefa. Logo, a busca de um quadro que sirva de referência para ações sociais, separada funcionalmente da via política, ficará prejudicada. Vai se ter anulado a diferença entre direito e política. Portanto, ter-se-á liquidado - previamente, do ponto de vista analítico - a compreensão de que os atores sociais entendem as decisões políticas como baseadas em uma fonte de autoridade e legitimidade diversa das decisões judiciárias. Será que esta pressuposição analítica é razoável para fundar uma base teórica?” (2009, p.271).

${ }^{3} \mathrm{Na}$ leitura de VIANNA et al., a judicialização da política e das relações sociais poderia propiciar uma conexão entre democracia representativa e a participativa: “a mobilização de uma sociedade para a defesa dos seus interesses e direitos, em um contexto institucional em que maiorias efetivas da população são reduzidas, por uma estranha alquimia eleitoral, em minorias parlamentares, não pode desconhecer os recursos que lhe são disponíveis a fim de conquistar uma democracia de cidadãos.” (2014, p.43) 
Assim, composto o quadro em que os demais poderes parecem não dar conta das necessidades do Brasil contemporâneo ${ }^{4}$, o STF surge como instância neutra responsável por garantir direitos fundamentais e viabilizar os pressupostos da democracia (NETO \& SARMENTO, 2015), como aquele capaz de materializar um equilíbrio argumentativo entre direito e política (MENDONÇA, 2015) e, ainda, como o interlocutor de diálogos institucionais, que constrói, em conjunto com os demais poderes, o significado constitucional, permitindo a consolidação da ideia de democracia como um debate público permanente (BRANDÃO, 2011).

Diante de tantas expectativas em torno da corte, a análise da dimensão política das suas práticas se revela essencial para investigarmos se a forma como exerce o seu poder realmente contribui para o aprofundamento da participação democrática. Em entrevista dada à revista Carta Capital de 02.05.2016, o professor Daniel Vargas avalia que os problemas relacionados ao Poder Judiciário não foram tratados como um elemento central do processo de democratização brasileiro e que nossa cultura jurídica preservou traços muitos similares àqueles que existiam no período autoritário. Após a Constituição de 1988, não teríamos mais um Supremo Tribunal Federal subserviente ao Executivo, mas, em contrapartida, também não teríamos desenvolvido critérios democráticos e autônomos de constrangimento da sua atuação.

Quando trafega livremente entre o jurídico e o político, o tribunal gera uma certa inquietação, que, algumas vezes, não consegue bem definir suas causas e se perde ao sabor das ideologias que perpassam o caso sob julgamento ${ }^{5}$. Assim, ao buscarmos uma legitimação verdadeiramente democrática para o Supremo, é importante que os aspectos jurídicos de sua atuação possam ser relacionados com as disputas de poder, observando como a performance política do tribunal se concretiza em seus diversos níveis. Neste sentido, é possível introduzir o conceito, criado por José Rodrigo Rodriguez, de zona de autarquia: aquele momento em que a forma jurídica se torna apenas uma aparência vazia para justificar a

\footnotetext{
${ }^{4}$ Alguns autores defendem, inclusive, que o próprio Congresso Nacional, de forma conveniente, tem deixado determinadas decisões para o Judiciário, já que as polêmicas a elas relacionadas poderiam gerar externalidades nem sempre proveitosas politicamente. Ao STF, assim, caberia deliberar “de maneira mais ponderada e técnica”, já que os ministros seriam menos suscetíveis “ao calor da opinião pública” (BAMBINI, 2013, p.77).

${ }^{5}$ A reportagem do Jota “As críticas ao STF pelo resultado do julgamento do impeachment”, de Felipe Recondo, ilustra bem esta situação. Disponível em: <https://jota.info/artigos/as-criticas-aostf-pelo-resultado-do-julgamento-do-impeachment-03012016>. Acesso em: 17 mai. 2017.
} 
arbitrariedade do poder público ou privado. Na linha do defendido por este autor, o papel do crítico seria, justamente, identificar as eventuais zonas de autarquia no interior das instituições formais, ou seja, perceber os momentos em que os padrões de legitimação se afastam daqueles democráticos para se aproximar dos padrões autoritários ou fundados apenas no poder simbólico (RODRIGUEZ, 2013, p.171-172).

O segundo ponto com base no qual se torna relevante enfatizar o STF em sua feição política diz respeito à necessidade de situar os tão falados fenômenos do ativismo e da judicialização da política. No Capítulo 2 deste trabalho, adentraremos na questão dos múltiplos significados destas expressões, mas, para o momento, o que importa assinalar é que, em alguns de seus sentidos, a ideia por trás destes conceitos presume uma atuação padrão das cortes constitucionais, das quais o ativismo e a judicialização da política seriam variantes determinadas por uma conjunção de fatores internos e externos à atividade jurisdicional. Esta concepção parte de uma visão formal das atribuições e das relações entre os poderes, que pode não se revelar verdadeira na realidade prática das instituições ${ }^{6}$. Se tivermos em mente que o tribunal tem ao seu dispor um instrumental jurídico, mas que também realiza escolhas políticas, o próprio ativismo ou autocontenção se revelarão como espécies destas escolhas que cabem à corte realizar. A partir desta concepção, elimina-se a visão de que haveria uma conduta desviante, encarando estes fenômenos como formas possíveis de manifestação do poder do tribunal. Na sua atuação, o Supremo poderá calibrar o seu grau de intervenção conforme o ambiente, a predisposição dos ministros e a expectativa social sobre seu papel. A questão, então, se desloca de uma possível usurpação de competências para a indagação sobre se uma instituição com estes poderes é a mais desejável para um aprofundamento democrático ou se as dificuldades de accountability pesariam contra este modelo.

Para demonstrar este argumento, o segundo capítulo traz alguns julgamentos históricos do Supremo, que contribuem para perceber como a corte

\footnotetext{
${ }^{6}$ Sobre este aspecto: “A operação das instituições dentro da separação de poderes é dinâmica. Elas negociam passo a passo seus raios de atuação. Mesclam atos de ativismo e contenção, ocupação e desocupação de espaço. Trata-se, sobretudo, de um processo informal (e não formalizável) de acomodações contingentes ditadas pela política, não por uma cartilha hermenêutica (o que não significa que "política", na acepção que aplico, não seja sensível a "boas razões", ponto do próximo capítulo).” (MENDES, 2008b, p.193)
} 
sempre lançou mão de estratégias jurídicas e políticas, considerando as circunstâncias que a cercavam, os interesses em jogo, o capital institucional do tribunal, dentre outros elementos. Assim, os ministros podiam lançar mão de uma interpretação heterodoxa de um texto legal ou contrariar jurisprudência recente para encaminhar a solução do caso em um determinado sentido, o que poderia ser visto como uma postura ativista em relação à aplicação do direito. Além disso, a análise destes casos permite verificar como o tribunal construiu seu personagem ao longo do tempo: afeito ao diálogo ou "guardião entrincheirado"7? Cuidadoso com a jurisprudência ou desapegado de sua estabilidade? Orquestra ou onze vozes dissonantes? Última trincheira da cidadania ou acovardado?

Diante desta boa dose de arbítrio que a corte dispõe no exercício de suas atribuições, resta indagar em que se sustentam as teorias que defendem a supremacia da jurisdição constitucional em detrimento das instâncias da política eleitoral. Como é possível concluir, a discussão em torno do papel do STF não consegue escapar aos debates sobre constitucionalismo e democracia. Nesse passo, é possível estruturar o tema em dois níveis. O primeiro é aquele no qual se situam as teorias que estudam as tensões e/ou convergências entre jurisdição constitucional e democracia. O modelo que privilegia o controle de constitucionalidade é o que melhor responde aos nossos anseios para uma sociedade mais justa e igualitária? Para discutir este ponto, o terceiro capítulo traz um panorama da literatura latino-americana, que tem se mostrado entusiasmada com a atuação das cortes constitucionais, bem como das teorias que, no Brasil, buscam legitimar a jurisdição constitucional.

O segundo nível é aquele construído a partir da análise concreta do tribunal como personagem na cena brasileira, que contribui para escrever os capítulos presentes e futuros da vida político-institucional do país. Neste diapasão, o quarto capítulo se dispõe a sobrepor a narrativa constitucional contemporânea à realidade prática do tribunal, de maneira que seja possível verificar em que medida o STF, de fato, honra as expectativas geradas em torno do papel da jurisdição constitucional.

\footnotetext{
${ }^{7}$ A expressão foi utilizada por Conrado Hübner Mendes (2008c) para se referir ao hábito do Supremo de afirmar que detém o monopólio da última palavra sobre o sentido da Constituição e que representa a última trincheira do cidadão.
} 


\section{2 \\ De leões de pé de trono a vanguarda iluminista: o STF e a construção de seu personagem político}

\section{1. \\ Sobre ativismo, judicialização da política e protagonismo do STF}

Tema recorrente na literatura jurídica atual, a judicialização da política ${ }^{8}$ vem sendo encarada como um fenômeno novo, capaz de tornar mais evidente a complexa relação entre os Poderes de Estado em nosso sistema político-jurídico. Andrei Koerner ${ }^{9}$, atento para o problema da vulgarização do uso do termo, fez um balanço dos sentidos que a expressão poderia assumir:

Judicializar pode significar a ampliação dos poderes dos tribunais, a intenção dos juízes de influenciar políticas públicas, as consequências, intencionais ou não, das decisões dos juízes de influenciar políticas públicas, as estratégias dos atores sociais, uma mudança macro-sociológica das democracias contemporâneas, como se vê nos trabalhos de Tate e Vallinder (1995). Política pode ser pensada como forma de organização da comunidade política (policy); domínio especializado da esfera de ação governamental ou sistema político (politics); decisões das instâncias estatais para direção política, política legislativa, política governamental, política social, política econômica (policy). Pode-se pensar política como as ações de sujeitos e coletividades voltadas para a realização de seus interesses individuais ou coletivos e de objetivos comunitários; e que, na medida em que se identificam como cidadãos portadores de direitos, a política torna-se uma forma de mobilização do direito. (2013, p.32-33)

Apesar da abundância de possibilidades semânticas, recentemente, tem-se utilizado a expressão de duas formas principais: a primeira seria relativa ao aumento da interferência judicial sobre políticas públicas e a segunda seria

\footnotetext{
${ }^{8}$ Para conceituar judicialização da política, costuma-se recorrer à obra de referência de C. N. Tate e T. Vallinder, intitulada The Global Expansion of Judicial Power e publicada em 1995. De acordo com este livro, judicialização da política e politização da justiça seriam expressões correlatas. A judicialização da política seria a expansão do poder de revisão judicial para alcançar as ações legislativas e executivas, enquanto a politização da justiça seria a utilização de procedimentos judiciais no âmbito dos Poderes Executivo e Legislativo, como, por exemplo, juízes e tribunais administrativos. (CASTRO, 1996; MACIEL, Koerner, 2002; MELLO, 2012)

${ }^{9}$ MACIEL e KOERNER (2002) apontam que, no Brasil, o debate público incorporou a expressão em sentido fortemente normativo, tornando-se um conceito pouco preciso e gerando trabalhos que partem de perspectivas bastante diversas.
} 
relacionada a uma espécie de ativismo, em que os juízes deixariam de aplicar a lei para promover suas concepções políticas.

Judicialização da política e ativismo são ideias que comumente andam juntas $^{10}$, mas o conceito de ativismo também possui variantes ${ }^{11}$. Marcos Paulo Veríssimo (2013) se socorre do texto “A origem e os sentidos correntes do ativismo judicial”, de Keenan D. Kmiec, para expor os significados possíveis do termo. De acordo com este autor, um juiz ativista poderia ser 1) aquele que invalida decisões de outros poderes, examinando sua qualidade segundo critérios mais ou menos objetivos ou mais ou menos impregnados de cunho moral; 2) aquele que não adere a precedentes ou a padrões de julgamento aplicados anteriormente, se distanciando de certa história interpretativa, criando nova jurisprudência e surpreendendo com a solução dada ao caso concreto; 3) aquele que cria direitos que parecem não estar explicitamente contidos no ordenamento jurídico; 4) aquele que interpreta normas de forma criativa, preferindo conferir a elas sentido diferente dos tradicionalmente aceitos e, por último; 5) aquele que julga orientado para um resultado, almejando um ponto de chegada, que não é fruto de uma conclusão natural do percurso, da colheita de provas, da interpretação, mas é algo que parece desejado de antemão ${ }^{12}$.

De fato, nos dias de hoje, é possível verificar, na atuação do Supremo Tribunal Federal, algumas das formas de ativismo listadas acima e, sobretudo, é possível notar uma predisposição do tribunal para decidir e interferir sobre matérias de cunho nitidamente político ${ }^{13}$. É nesse clima que, proferindo palestra

\footnotetext{
${ }^{10}$ Segundo Luís Roberto Barroso (2009): “A judicialização e o ativismo judicial são primos. Vêm, portanto, da mesma família, frequentam os mesmos lugares, mas não têm as mesmas origens. Não são gerados, a rigor, pelas mesmas causas imediatas. A judicialização, no contexto brasileiro, é um fato, uma circunstância que decorre do modelo constitucional que se adotou, e não exercício deliberado de vontade política. (...) Já o ativismo judicial é uma atitude, a escolha de um modo específico e proativo de interpretar a Constituição, expandindo seu sentido e alcance. Normalmente ele se instala em situações de retração do Poder Legislativo, de um certo descolamento entre classe política e a sociedade civil, impedindo que as demandas sociais sejam atendidas de maneira efetiva."

${ }^{11}$ Sobre diversas formas de manifestação de ativismo judicial, ver: CAMPOS, Carlos Alexandre de Azevedo. Dimensões do Ativismo Judicial do STF. Rio de Janeiro. Forense: 2014.

${ }^{12}$ Nesta última acepção, o ativismo se aproxima da forma como o Realismo Jurídico procura olhar o fenômeno da aplicação do direito. Para esta corrente de pensamento, a decisão dos juízes parece ser anterior à sua justificação, ou seja, para compreender as razões que levaram um juiz a decidir de determinada maneira, deve-se investigar outros elementos que não exclusivamente as justificativas legais ou formais (VERÍSSIMO, 2013).

${ }_{13}$ Alguns trabalhos, baseando-se em pesquisa empírica sobre o julgamento de Ações Diretas de Inconstitucionalidade, questionam a afirmação de uma maior intervenção do Poder Judiciário em políticas públicas. Pelos números apresentados, o tribunal não poderia ser considerado um ator de
} 
no II Congresso de Internacional de Direito Constitucional e Filosofia Política, o Ministro Luís Roberto Barroso afirmou que, em algumas situações, o Supremo Tribunal Federal deve funcionar como uma vanguarda iluminista, "empurrando a história” nos momentos necessários. Já presidente do STF, Ricardo Lewandowski, em discurso proferido na abertura do $22^{\circ}$ Congresso Brasileiro de Magistrados em Caldas Novas, afirmou que a missão do Poder Judiciário no século XXI é participar da formulação de políticas públicas, avaliando ser preciso entrar no "fascinante universo da macropolítica” sem, evidentemente, se deixar contaminar por agremiações partidárias.

Uma leitura possível deste fenômeno é de que ele seria uma expressão das chamadas "operações de despolitização do mundo"14, inserido em um contexto de despotismo judiciário do século XXI, que teria sucedido o despotismo econômico do século XX (CHALHOUB, 2016). Entretanto, por mais que o domínio da técnica jurídica pareça obscurecer a dimensão política da atuação dos tribunais, é fundamental trazê-la para a superfície do debate. É necessário lembrar que o Poder Judiciário, aqui representado por seu órgão de cúpula, o STF, é uma instituição do jogo político como as demais, que lançará mão de estratégias de cálculo político institucional, das quais o ativismo ou a contenção podem ser um dos vários exemplos.

destaque no sistema político brasileiro, pois não teria atuado, de fato, bloqueando políticas majoritárias. (VIANNA, CARVALHO, MELO, BURGOS, 1999; DA ROS, 2007). Haveria, assim, na análise corrente, um hiperdimensionamento do caráter procedimental da judicialização, ou seja, do aumento do número de processos judiciais, e um hipodimensionamento do caráter substancial, isto é, da análise de que até que ponto os juízes modificam leis ou atos dos demais poderes (CARVALHO, 2004). Entretanto, Taylor (2007) pondera que, mesmo constatando que o STF vem agindo de forma cautelosa e conservadora para evitar conflitos com o Executivo, sua atuação é significativa, sendo que, nos 15 anos entre 1988 e 2002, concedeu liminares e proferiu decisões de mérito em ADINs invalidando parcialmente mais de 200 leis federais. Além disso, a título de exemplo, assinala que das 10 principais iniciativas políticas aprovadas durante o governo Fernando Henrique Cardoso todas foram contestadas de alguma forma pelo Judiciário e 7 das 10 foram alteradas ou atrasadas de alguma maneira no STF. Este autor lembra, ainda, que o Judiciário tem capacidade de influenciar a discussão de políticas públicas antes de elas serem aprovadas, sinalizando suas preferências, bem como as fronteiras que as mudanças provocadas por estas políticas podem atingir. Os juízes sinalizam suas preferências publicamente muito antes da aprovação final dos projetos seja por meio de pronunciamentos públicos seja por meio de reuniões a portas fechadas com membros do Executivo ou Legislativo. Com este tipo de atuação, sem utilizarem seus poderes formais, eliminam algumas alternativas e constrangem a liberdade de ação de outros atores políticos. Outra possibilidade de interferência no processo de implementação de políticas públicas se daria no controle de timing: o STF poderia acelerar o processo judicial por meio de liminar ou retardá-lo através de um pedido de vista. Ou seja, seu potencial de intervenção iria muito além da revisão judicial, contando com uma boa variedade de estratégias.

${ }^{14}$ Expressão utilizada por Sidney Chalhoub no artigo "Moro é o Alienista de Machado de Assis". Disponível em: <http:/www.diariodocentrodomundo.com.br/moro-e-o-alienista-de-machado-deassis-por-sidney-chalhoub-de-harvard/> . Acesso em: 10 jun. 2016. 
Assim, para uma melhor compreensão deste protagonismo do STF seria necessário contemplar não apenas sua visão jurídica, mas também uma perspectiva oriunda da ciência política, reconhecendo que direito e política possuem implicações recíprocas. O olhar do cientista político permite enxergar as relações de poder que estão implícitas nos conceitos e teorias utilizados, bem como nas peculiaridades da linguagem jurídica.

Sob este ângulo, torna-se possível problematizar o limite construído entre democracia e Judiciário. É que, considerando as lições de O Federalista (MADISON et. al, 1993), obra fundante de engenharia constitucional moderna, este Poder nasce como uma solução liberal ${ }^{15}$ para problemas democráticos ${ }^{16}$ (ARANTES \& KERCHE, 1999). Sua função primordial seria controlar os demais Poderes e evitar a tirania da maioria. O governo popular poderia gerar distorções que demandariam mecanismos de contenção. Nesse sentido, atribuir ao Judiciário a tarefa de preservar a Constituição em face dos poderes políticos é tornar o Estado mais liberal (ARANTES \& KERCHE, 1999). Existiria, portanto, um certo dilema em compatibilizar controle de constitucionalidade e democracia ${ }^{17}$, questão muitas vezes discutida sob o rótulo da “dificuldade contramajoritária”. O problema, com certeza, não é simples: uma democracia plena dependeria da existência de cidadãos dotados de um grau básico de autonomia para exercer com desenvoltura seus direitos de participação política, ou seja, os direitos políticos

15 A concepção de "liberal” aqui utilizada é aquela associada à preocupação de redução das oportunidades de exercício despótico do poder político, de acordo com o artigo $\mathrm{X}$, de $\mathrm{O}$ Federalista.

16 “A completa independência dos tribunais de justiça é peculiarmente essencial numa Constituição limitada. Por Constituição limitada entendo uma que contenha certas exceções especificadas ao Poder Legislativo, como, por exemplo, a de que ele não aprovará decretos de perda de direitos civis, leis ex post facto ou coisas semelhantes. Na prática, limitações desse tipo só podem ser preservadas por meio dos tribunais de justiça, cuja missão deverá ser declarar nulos todos os atos contrários ao sentido manifesto da Constituição” (MADISON, HAMILTON E JAY, 1993, p.480).

${ }^{17}$ Jeremy Waldron (2009) discute, em artigo no qual rebate os argumentos de Dworkin a favor do judicial review, a questão das fontes de legitimidade da jurisdição constitucional, concluindo que "sempre há perda para a democracia quando o ponto de vista a respeito das condições democráticas é imposto por uma instituição não-democrática, mesmo que este ponto de vista seja correto e apresente melhorias à democracia.” (p.269). Em outro extremo, alguns autores defendem a possibilidade de um constitucionalismo democrático que, em contraposição ao constitucionalismo liberal, priorizaria a dignidade da pessoa humana e a solidariedade social. A partir desta concepção, se abriria ao Judiciário um novo espaço público, no qual participariam novos agentes, permitindo uma interpretação aberta dos valores compartilhados pela comunidade. Sua atuação, neste contexto, não seria contrária à política democrática, mas estaria em consonância com ela (CITTADINO, 2000). 
dependeriam dos direitos civis para terem eficácia garantida. A existência de um Estado Liberal, nesse passo, ao limitar os Poderes instituídos, poderia contribuir para a construção de uma cidadania civil que abrisse campo para uma maior democratização, mas, por outro lado, conviveria com elementos de restrição da vontade popular. Encontrar este ponto de equilíbrio parece ser o que atormenta boa parte dos estudiosos do tema e, como coloca Diego Werneck Arguelles (2015), talvez a dificuldade contramajoritária não seja, de fato, algo superável, mas um desafio prático constante com que tenhamos que lidar cotidianamente.

Nessa linha, assumir que o Judiciário é um elemento liberalizante das democracias contemporâneas não implica aceitar que ele se mantenha totalmente alheio a práticas democráticas. Ao contrário, ainda que não encontre sua fonte de legitimação ${ }^{18}$ diretamente na soberania popular (ou até por esta própria razão), este poder precisa prestar contas à sociedade ${ }^{19}$. A afirmação de sua legitimidade em uma suposta independência da jurisdição em relação à política parece ter cada vez menos aceitação. A tentativa de negar as relações entre as forças políticas, o debate técnico-jurídico e as decisões do tribunal apenas nubla os elementos da discussão, permitindo o fortalecimento de um poder cada vez menos aberto ao diálogo, e, neste sentido, autoritário, que se protege investindo na autonomia e no monopólio da linguagem do Direito. A busca por legitimação passaria, portanto, por um esforço de expor estas relações, permitindo uma maior transparência no processo decisório do órgão de cúpula do Poder Judiciário, responsável pela última palavra em questões de extrema relevância para a sociedade.

Um olhar histórico contribui para revelar que as regras constitucionais não se sustentam sozinhas e que, a despeito do ambiente normativo, é o jogo de forças

\footnotetext{
${ }^{18}$ Em artigo intitulado "A razão sem voto”, Luís Roberto Barroso (2015) afirma que o papel contramajoritário do controle de constitucionalidade teria se tornado quase universalmente aceito com base em dois fundamentos principais: 1) a proteção dos direitos fundamentais, que configurariam um mínimo ético de uma comunidade política e 2) a proteção das regras do jogo democrático e dos canais de participação política de todos. Mesmo que assumidos como corretos estes fundamentos, ainda seria necessário discutir quais os limites da atuação das cortes constitucionais e o que se espera delas do ponto de vista de seu papel institucional. Nas palavras de Diego Werneck Arguelles (2015), "sempre haverá questões que, em uma democracia, não deveriam ser resolvidas em última instância por um grupo de sábios não-eleitos e que permanecem no cargo por décadas, sem qualquer tipo de accountability política”. Seria necessário refletir, portanto, em que momentos o exercício deste poder seria justificado.

${ }^{19}$ Julio Ríos Figueroa (2010) observa que tanto os experts com experiência prática quanto os acadêmicos concordam com a afirmação de que a onda de reformas judiciais que ocorreu na América Latina nas últimas décadas do século XX, em termos gerais, fortaleceu a independência judicial, ao ponto de, agora, ser necessário o desenvolvimento de mecanismos de prestação de contas para alcançar um melhor equilíbrio.
} 
entre os agentes políticos que irá determinar ou não sua observância ${ }^{20}$. Em vista disso, o que se pretende demonstrar neste capítulo é que a tensão entre direito e política acompanha a própria história do STF, que, sempre lançando mão de argumentos de natureza jurídica, lidou com ela de formas diversas ao longo do tempo. Em outras palavras, se hoje é possível notar um protagonismo deste tribunal nas questões políticas, também é verdade afirmar que, em vários momentos do passado, o STF foi chamado a garantir direitos individuais em tempos de grave crise política, sendo que sua maior ou menor intervenção não se deu de forma insensível ao ambiente externo em que operava. A política, assim, esteve presente nas características de seus procedimentos institucionais, sendo possível, inclusive, dizer que, em alguns momentos, o tribunal foi ativista em dois dos sentidos anteriormente listados: (i) aquele que qualifica o juiz que não adere a precedentes ou a padrões de julgamento e (ii) aquele ligado a realização de julgamentos orientados a um resultado, em que há, claramente, um ponto de chegada desejado independente do percurso processual seguido.

Diante disso, talvez a postura a ser assumida não seja a de combater a judicialização da política, mas a de concentrar esforços em desnudar e aceitar como opções políticas $^{21}$ determinadas posições da corte para, a partir daí, abrir o campo para a crítica que demanda uma maior democratização de suas práticas. O caminho, assim, seria jogar mais luz no que há de político em seu modus operandi e menos na natureza dos casos que são levados à apreciação, permitindo identificar e trazer para o centro da discussão os momentos em que a forma jurídica é apenas uma aparência vazia, se afastando de um padrão democrático de legitimação. Ao fazê-lo, retiramos o STF de seu lugar hierarquicamente superior, de único detentor do saber técnico-jurídico, para trazê-lo de volta ao mesmo patamar dos demais atores do jogo político institucional, sujeito, assim como eles, a questionamentos das mais diversas naturezas sobre sua atuação. Assim como os outros poderes, ele não pode escapar de uma constante demanda por legitimação democrática.

\footnotetext{
${ }^{20}$ Esta conclusão remonta a Ferdinand Lassalle (1998), que, em sua obra pioneira, dá destaque aos fatores reais do poder que regem uma determinada sociedade. No Brasil, esta ideia também é trabalhada por Oliveira Vianna em o Idealismo da Constituição (1927).

${ }^{21}$ Estas opções se aproximariam do que Nuno Garoupa (2016) chama de judicial politics, que seria a dimensão da atuação política da corte que teria relação com o esforço para expandir competências e aumentar seu prestígio, por exemplo.
} 
A novidade dos tempos atuais, portanto, talvez possa ser traduzida por uma correlação de forças que permite a independência do Poder Judiciário ${ }^{22}$, ministros dispostos a participar da vida política $^{23}$ e uma ampliação de competências materiais do STF diante da maior constitucionalização de direitos.

Outra característica que marcaria o momento em que vivemos é um certo monopólio do discurso jurídico conquistado pelo Judiciário em detrimento dos demais Poderes, que parecem ter reconhecido (ou terem sido forçados a reconhecer em razão do novo equilíbrio de forças) a autonomia do Direito como linguagem técnica. Quando ocorrem, as reações políticas às decisões da corte $\mathrm{e}^{24}$ não contêm, em sua maioria, um questionamento mais relevante das razões jurídicas que as fundamentaram ou do procedimento de deliberação adotado e têm recebido respostas institucionais veementes. Acusando qualquer crítica aos julgamentos (ou até aos ministros) de tentativa espúria de controle do tribunal, o STF tem tido sucesso na realização de uma blindagem institucional de inquirições mais profundas sobre sua atuação ao menos no que se refere aos demais atores do jogo democrático ${ }^{25}$.

\footnotetext{
${ }^{22}$ Matthew Taylor (2007) se pergunta por que, no caso brasileiro, um Executivo poderoso cumpre as decisões de um Judiciário que o contraria proativamente. Mesmo reconhecendo que a questão ainda é pouco estudada, levanta algumas hipóteses para explicar o interesse em preservar a independência desta instituição: a alternância de poder e a utilização do Judiciário como legitimador as decisões do governo (se, algumas vezes contraria, quando chancela, confere força à posição política do Executivo). A este rol do autor seria possível acrescentar o alto capital institucional conquistado pelo STF nos últimos anos, principalmente, depois do julgamento da Ação Penal $n^{\circ} 470$, conhecida popularmente como Mensalão, tornando custoso politicamente entrar em conflitos diretos com a instituição.

${ }^{23}$ Sobre a forma como os próprios ministros configuram e definem o papel do STF por meio de práticas institucionais e interpretações de seus poderes, ver: ARGUELLES, Diego Werneck; RIBEIRO, Leandro Molhano. Criador e/ou Criatura: transformações do Supremo Tribunal Federal sob a Constituição de 1988. Revista Direito GV, v. 12 n. 2, mai-ago 2016.

${ }^{24}$ As reações aqui referidas poderiam ser classificadas como informais porque ocorrem à margem das regras do jogo vigente, em contraposição a reações tidas como formais que ocorreriam por meio de canais e estratégias oficiais (ARGUELLES \& RIBEIRO, 2013). Como exemplo do tipo de resposta política informal mencionada em: <http://g1.globo.com/politica/noticia/2016/04/cunha-chama-decisao-de-marco-aurelio-de-absurdae-diz-que-vai-recorrer.html>.

${ }^{25}$ Como exemplo de resposta veemente às críticas sofridas pelo STF, podemos citar o ofício encaminhado pelo tribunal à Polícia Federal para que fossem tomadas providências a respeito de bonecos infláveis que representavam o ministro Ricardo Lewandowski e o Procurador-Geral da República, Rodrigo Janot, associando-os ao Partido dos Trabalhadores. Os bonecos foram expostos em manifestação na Avenida Paulista em 19.06.2016. (http://oglobo.globo.com/brasil/stf-quer-que-pf-investigue-manifestantes-que-levaram-boneco-delewandowski-manifestacao-19658371). Outro episódio de discurso enérgico em defesa da corte ocorreu a propósito da divulgação dos grampos de conversas telefônicas entre a presidente Dilma Rousseff e o ex-presidente Lula. A interceptação telefônica, tornada pública dia 16.03.2016, continha trechos em que Lula afirmava que o STF e o STJ eram tribunais acovardados. O ministro
} 
Investindo nesta postura intransigente em relação às críticas, a discussão sobre alguns elementos que definem a identidade da corte acabam ficando em segundo plano quando se trata de debater a judicialização da política, como, por exemplo, a forma como ela define para si uma agenda mais ativa ou mais passiva, que se reflete nos conflitos em que se mostra disposta a entrar, a liberdade de atuação individual dos ministros seja no exercício de atribuição judicante seja em suas manifestações e atividades fora do tribunal, bem como a relação que estabelece com a própria jurisprudência.

Nessa linha, para uma análise comparativa do papel político do STF em outros momentos históricos, é muito útil o estudo realizado por Luciano da Ros (2007), que associa o aumento da independência dos tribunais - e o eventual ativismo daí decorrente - à maior distribuição das forças políticas no cenário institucional. Segundo este autor, é possível afirmar que as análises recentes de diversos cientistas políticos têm convergido para constatar que "quanto mais concentrado o poder no sistema político (seja em um partido, em uma instituição, em uma coalização de governo), menos independentes e ativas tenderão a ser as cortes” (DA ROS, 2007, p.94). Em contrapartida, quanto maior a divisão do poder político, maior a independência do Judiciário, abrindo campo para o ativismo e para a judicialização da política.

Para demonstrar seu argumento, ele parte de dois tipos-ideais de atuação dos tribunais: a) como árbitros, naquelas situações em que atua julgando conflitos entre um elevado número de atores com poderes bastante semelhantes entre si, o que tende a se verificar em ambientes políticos com poderes divididos; e b) como instrumentos de oposição, quando são empregados majoritariamente pela oposição - e demais grupos adversários do governo - para que amplifiquem suas denúncias

Celso de Mello, em pronunciamento em sessão plenária de 17.03.2016, afirmou que a frase "traduz, no presente contexto da profunda crise moral que envolve os altos escalões da República, reação torpe e indigna, típica de mentes autocráticas e arrogantes que não conseguem esconder, até mesmo em razão do primarismo de seu gesto leviano e irresponsável, o temor pela prevalência do império da lei e o receio pela atuação firme, justa, impessoal e isenta de Juízes livres e independentes, que tanto honram a Magistratura brasileira e que não hesitarão, observados os grandes princípios consagrados pelo regime democrático e respeitada a garantia constitucional do devido processo legal, em fazer recair sobre aqueles considerados culpados, em regular processo judicial, todo o peso e toda a autoridade das leis criminais de nosso País" (http://politica.estadao.com.br/blogs/fausto-macedo/leia-a-manifestacao-do-ministro-celso-demello-em-reacao-a-lula-no-grampo/). 
a medidas eventualmente impopulares daquele que é provavelmente o principal policy-maker e centro da dinâmica política.

Na primeira hipótese, se julgar a favor de qualquer uma das partes não possuiria um custo político idêntico, ele seria muito semelhante. Logo, as considerações sobre as consequências políticas da decisão judicial poderiam ser minimizadas, abrindo espaço para decisões mais autônomas e menos centradas no cálculo estratégico de apoio político ao julgamento. Os tribunais funcionariam como árbitros porque poderiam resolver problemas de coordenação entre os atores políticos em temas muito controversos, atuando em uma zona de vazio de poder ou em uma área em que as preferências dos agentes institucionais se anulariam. Tornariam-se, em razão disso, importantes órgãos de dinâmica política.

Na segunda hipótese, considerando a concentração de poder, é provável que o principal policy-maker seja também o principal alvo de ações judiciais, movidas por grupos oposicionistas que buscam ampliar sua voz no sistema político. Neste contexto, é possível que o tribunal venha a apresentar uma atitude mais permissiva e silente ante o que se decide no âmbito da política, influenciado pelo temor de contrariar o principal ator político existente. $\mathrm{O}$ autor conclui que:

O que se verificaria nessas situações é uma situação ambígua na qual os juízes são verdadeiramente independentes da dinâmica política (protegidos por uma série de prerrogativas pessoais, funcionais e profissionais), mas o Poder Judiciário, enquanto instituição, ao contrário, é razoavelmente dependente das correlações de forças existentes no sistema político para que se sustente decidindo independentemente, o mesmo valendo para que suas decisões sejam verdadeiramente implementadas. Aquilo que pode ser designado risco de retaliação das decisões judiciais é talvez, e provavelmente, um dos principais determinantes do modo como se processa a decisão judicial. Isto é: eventuais decisões legislativas ulteriores, após uma decisão judicial que contrarie os interesses dos atores políticos majoritários, podem revogar, pela aprovação de uma lei, a referida decisão dos juízes, estabelecendo uma espécie de sanção à atuação da corte. Pode-se afirmar que o cálculo em função desta eventual retaliação é um dos poderosos fatores que contribui para que os tribunais não se afastem do círculo de preferências do principal policy-maker. Neste mesmo sentido pode ser entendido o que se poderia chamar de risco de frustração da decisão por não implementação, isto é, a possibilidade de que os demais atores políticos simplesmente ignorem a decisão, descumprindo-a, acarretando forte desmoralização e desprestígio à própria instituição do Poder Judiciário. Quando houver apenas um ator realmente poderoso no sistema político, não haverá nenhum outro capaz de fazê-lo obedecer àquelas decisões, o que pode ser um forte estímulo para que os tribunais decidam em sintonia com as preferências deste ator político principal. Mais grave que estas duas, entretanto, é o que se poderia chamar risco de retaliação institucional. Isto ocorre quando eventuais sanções legislativas são realizadas não apenas contra certas decisões judiciais, mas também e contra suas prerrogativas básicas. Algo que os juristas 
frequentemente ignoram é que a decisão pela existência de um Poder Judicial independente é também uma decisão política, que se sustenta praticamente como qualquer outra. Muitos governantes possuem capacidade real de revogá-la ou de ameaçá-la - e freqüentemente o fazem - sinalizando para que os magistrados adotem uma postura menos ativa e mais comedida (DA ROS, 2007, p.98).

Além desta análise dos elementos externos, é preciso considerar também a contribuição pessoal dos ministros que compõem o tribunal para o papel a ser por ele exercido, já que estes, em um mesmo cenário normativo e de divisão de poder, podem manifestar preferência por uma postura mais expansiva ou mais restritiva quanto às suas competências. Diego Werneck Arguelles (2014) assinala que a previsão textual de atribuições e a demanda de atores sociais e políticos por maior intervenção judicial não são suficientes para determinar o grau de participação de um tribunal na vida política de um país em um dado momento. O autor chama atenção para a importância de variáveis não-exógenas, demonstrando como os ministros precisam estar dispostos a participar da vida política, exercendo preferências não restritivas de seu poder. Nesta hipótese, acabariam por ser responsáveis por conferir novos contornos ao desenho institucional através de uma ampliação de competências da corte.

\section{2.}

\section{A construção do personagem político ao longo da história}

Conforme exposto acima, o personagem político desempenhado pelo Supremo é resultado de uma conjunção de fatores. Dentre estes fatores, a história da instituição não pode ser desconsiderada. Não se pretende, aqui, recontá-la em detalhes, mas lançar um olhar sobre a construção da sua trajetória ao longo do tempo. A opção metodológica realizada, portanto, neste capítulo foi de trazer à baila alguns julgamentos em que relevantes questões políticas foram debatidas desde a Primeira República até a Constituição de 1988 para observar as saídas encontradas diante dos impasses entre direitos fundamentais e da relação a ser estabelecida com os demais poderes, além de notar como o próprio STF entendia o seu papel e o representava fora do ambiente do tribunal. É possível averiguar, também, a atuação da corte no que compete aos elementos da técnica jurídica, 
como a qualidade da fundamentação elaborada e o respeito à própria jurisprudência. A escolha dos acórdãos não teve como pretensão apresentar um quadro exaustivo do que foi a relação entre direito e política ao longo da história brasileira, mas apenas de ilustrar a tese de que o STF e seus ministros sempre foram atores políticos, cuja participação em cena, por mais que tenha tido importância oscilante, trazia para o debate tanto argumentos de cunho jurídico como estratégias de cunho político-institucional. Se não se pode dizer que a corte era política no sentido de exercer proselitismo partidário, é possível afirmar que o era ao lançar mão de diversos mecanismos para buscar legitimar sua atuação, para preservar sua imagem, para aumentar seu capital institucional e para garantir a eficácia de suas decisões. Logo, para o diagnóstico completo da performance política do STF, é necessário ir além da simples verificação do resultado dos julgamentos realizados, mas observar também o conjunto de suas práticas institucionais.

Diante disso, este levantamento do passado institucional tende a revelar os caminhos trilhados pelo tribunal, indicando eventuais continuidades e rupturas que ajudarão a lapidar a figura do Supremo nos dias atuais. Se hoje tem pretensões iluministas ${ }^{26}$, a instituição também já conviveu com representações mais tímidas em sua história.

\subsection{1. Início republicano}

Os primeiros anos da República no Brasil são comumente definidos como caóticos, marcados pelo vazio deixado pelo abandono dos critérios monárquicos de organização do espaço público. O sistema político brasileiro precisava lidar com a ausência do Poder Moderador, chave da engenharia política no período imperial. Na leitura de Renato Lessa (2008):

Os primeiros anos republicanos se caracterizaram mais pela ausência de mecanismos institucionais próprios do Império do que pela invenção de novas formas de organização política. O veto imposto ao regime monárquico não

\footnotetext{
${ }^{26}$ Luís Roberto Barroso utilizou a expressão "vanguarda iluminista” para definir um dos papéis que, a seu ver, devem ser exercidos pelas cortes constitucionais (2015, p.4).
} 
implicou a invenção positiva de uma nova ordem. O que se seguiu, conforme será visto, foi uma completa desrotinização da política, o mergulho no caos.

(...)

O Brasil acordou sem Poder Moderador, em 16.11.1889. Isto é, sem ter qualquer resposta institucional a respeito de si mesmo: quem faz parte da comunidade política, como serão as relações entre polis e demos, entre o poder central e as províncias, como se organizarão os partidos e se definirão as identidades políticas. Enfim, sobre quem deverá mandar, pois como disse Silvio Romero: “A questão toda hoje no Brasil é saber com que patrão se há de estar.” (LESSA, 2008, p.43 et. seq.)

O STF foi instalado em 28.02.1891 em meio a este quadro de instabilidade. A Constituição de 1891, inspirada no modelo norte-americano, ampliou o papel do Judiciário ao instituir expressamente o controle de constitucionalidade das leis (art. 59, parágrafo $1^{\circ}$ ), ainda que apenas de forma incidental. Fábio Carvalho Leite (2003) lembra que:

Embora um órgão de cúpula do Poder Judiciário não figurasse como novidade na organização constitucional do País, já que a Constituição do Império abrigava o Supremo Tribunal de Justiça (art.164), o STF assumiria, nos termos definidos pela Constituição de 1891, atribuições desconhecidas até então pelo Poder Judiciário brasileiro e, nada obstante a sua composição inicial ter sido, em maior parte, originária dos ministros do Supremo Tribunal de Justiça, pode-se afirmar que o STF surgiu como um novo ator na ordem constitucional que se inaugurava. (LEITE, 2003, p.157)

Assumir, porém, esse novo papel não seria fácil e encontraria forte resistência em vários segmentos da sociedade. Logo de início, o tribunal teve que lidar com inúmeros conflitos surgidos a partir da implantação da experiência federalista, quando o governo central se viu obrigado a reconstruir os mecanismos de poder nos estados e subordiná-los a uma ordem nacional. Nesse contexto de agitação, um instrumento utilizado de forma recorrente pelo Poder Executivo era a decretação do estado de sítio, que suspendia a aplicação das garantias constitucionais ${ }^{27}$.

Diante dos diversos decretos de estado de sítio $^{28}$, o Supremo, ao ser chamado a se manifestar sobre a violação de direitos, tinha que enfrentar algumas

\footnotetext{
${ }^{27}$ Heloisa Fernandes Câmara (2014, p.956) assinala que: “A ampla utilização do estado de sítio neste momento de república nascente pode ser visualizada quando notamos que somente os presidentes Campos Sales, Afonso Pena, Nilo Peçanha e Delfim Moreira não invocaram em nenhum momento este instituto".

${ }^{28}$ A utilização do mecanismo teve início no governo do Marechal Floriano Peixoto, mas estes decretos foram mais utilizados no governo de Arthur Bernardes (1922-1926), que alcançou a marca de 1.287 dias em estado de sítio (CÂMARA, 2014).
} 
questões preliminares, como a constitucionalidade do próprio decreto, sua abrangência em relação aos atos praticados pelos sujeitos que se diziam vítimas de ilegalidade, além da admissibilidade de habeas corpus, quando fosse o caso do ajuizamento desta ação, para tutela da lesão apontada e enquanto vigorava a medida de exceção. A depender de como decidisse nestas preliminares, poderia abrir caminho para chancelar ou não a postura repressiva do Executivo. Estas decisões, portanto, precisavam levar em conta a avaliação dos riscos de contrariar os interesses do poder instituído e de ter, eventualmente, suas decisões flagrantemente desconsideradas.

Na leitura feita por Raimundo Faoro, Rui Barbosa acreditou que a solução para controlar os militares e evitar o estadualismo era um "governo de juízes”, reconhecendo o STF como herdeiro do Poder Moderador, acima das facções e dos interesses. No entanto, esta ideia de justiça como "chave de todo problema” não se concretizou por aqui ${ }^{29}$, não passando de uma tentativa idealizada de transplante da experiência norte-americana:

O destino da República não dependia de quinze velhos, muitos de indiscutível desassombro. Não foi o Supremo Tribunal o órgão que falhou à República, mas a República que falhou ao Supremo Tribunal. A missão política que ele deveria representar estava destinada a outras mãos, alimentadas de forças reais e não de papel. (2012, p.749)

Cabe mencionar que foram vários os episódios em que o governo se recusou a cumprir o determinado pelo $\mathrm{STF}^{30}$ (RODRIGUES, 1991), o que corrobora a tese de Luciano da Ros no sentido de que, em ambientes de extrema concentração de Poder, não existem forças capazes de obrigar ao cumprimento das decisões, o que repercute no tipo de atuação dos tribunais. Temendo represálias ou a sua desmoralização, eles tendem a ser mais permissivos e silentes quanto à política. Porém, mesmo sem atender às grandes expectativas de Rui Barbosa, neste período, é possível observar o tribunal estabelecendo as bases de

\footnotetext{
${ }^{29}$ No mesmo sentido, Oscar Vilhena Vieira (2008) destaca que Rui Barbosa, em 1914, advogava uma centralidade política para o Supremo, mas que a "história institucional da República, no entanto, seguiu rumos mais acidentados. O papel de árbitro último dos grandes conflitos institucionais que, no Império, coube ao Poder Moderador, foi exercido, sobretudo, pelo Exército, como reivindica Alfred Stepan, e apenas subsidiariamente pelo Supremo, como propõem José Reinaldo Lima Lopes e eu mesmo.”

${ }^{30}$ Como exemplos de descumprimento por parte do Executivo: HC n ${ }^{\circ} 520$ de 1894, que envolvia a deportação de estrangeiros e o HC n604, de 1894, que envolvia a soltura do capitão-tenente Huet Barcelar.
} 
suas relações com os demais poderes e tentando se consolidar como uma das forças do cenário político da época.

Data desta fase a chamada doutrina brasileira do habeas corpus, que conferia uma maior amplitude a este instrumento para alcançar hipóteses em que não havia constrangimento físico direto do paciente. De acordo com SOUZA (2008), esta tese não foi plenamente adotada na jurisprudência do STF, que oscilava entre uma concepção mais ortodoxa do instrumento, limitada apenas à liberdade de ir e vir, e uma outra intermediária, que encarava a liberdade de locomoção como condição necessária para o exercício de outros direitos que, por isso, poderiam ser protegidos por habeas corpus.

Outro complicador na observação da aplicação desta doutrina diz respeito aos conflitos oligárquicos que motivavam muitos dos habeas corpus impetrados perante o STF, dificultando sua análise pela ótica estritamente jurídica. Estudo realizado por Andrei Koerner (1998), tomando por base decisões de 1908 a 1911, conclui que é possível identificar dois entendimentos contrastantes entre os ministros nos julgamentos do período: 1) o de que o habeas corpus tinha ampla aplicabilidade para os casos políticos, já que o instituto era garantia imediata de liberdade individual, sendo que, assumindo esta posição, o ministro tendia a conceder a ordem e; 2) a de que o habeas corpus só caberia em casos de atentado ilegal contra liberdade de locomoção.

O autor assinala que, para os grupos em disputa, “era irrelevante a posição doutrinária que defendiam no STF, pois, para vencer, uma mesma facção podia adotar doutrinas opostas em casos semelhantes ou defender doutrinas contraditórias num mesmo caso”(p.194). Quanto aos ministros, suas posições variavam a depender do caso julgado, sendo possível constatar, ainda segundo este autor, que seus votos acompanhavam as posições dos chefes políticos a que estavam ligados. Neste contexto, a politização do tribunal seria ainda mais manifesta, com julgamentos determinados pelas preferências político-partidárias da maioria dos ministros. 


\subsubsection{1.}

$\mathrm{HC} \mathrm{n}^{\circ} \mathbf{3 0 0}$

Este famoso habeas corpus foi impetrado por Rui Barbosa, no ano de 1892, em favor do Senador Almirante Eduardo Wandenkolk e outros cidadãos. O clima era de crise, já que Floriano Peixoto havia assumido o poder após a renúncia de Deodoro da Fonseca, que cedeu a pressões civis e militares depois de uma tentativa fracassada de golpe em novembro de 1891. Floriano, então, assume, convoca o Congresso que havia sido dissolvido e logo dá início à deposição dos governadores deodoristas.

Em abril de 1892, os jornais do Rio publicam o Manifesto dos 13 Generais, na forma de carta ao Vice-Presidente da República, em que os signatários se mostram contrários à deposição dos governadores e pedem a realização de eleições para Presidente da República. Floriano responde reformando estes militares e, diante da agitação popular, manda efetuar várias prisões, dentre elas de senadores, deputados, jornalistas e oficiais do Exército, desterrando 46 presos e decretando estado de sítio por 3 dias. Algumas das referidas prisões ocorreram antes mesmo deste decreto e depois dele.

Rui Barbosa, então, impetra habeas corpus em favor de Eduardo Wandenkolk e outros, provocando reação na imprensa governista que considerava a medida inoportuna e enfrentando um clima de intimidação, onde corria como verdadeira a frase atribuída a Floriano Peixoto, segundo a qual, se os juízes concedessem o habeas corpus aos detidos, não se sabe quem concederia, amanhã, o habeas corpus de que precisariam (RODRIGUES, 1991).

Rui Barbosa sustentava, em sua petição, que os pacientes estavam divididos em três grupos: os que haviam sido presos antes do decreto do estado de sítio, os que haviam sido presos depois de cessado o estado de sítio, dentre eles o senador Eduardo Wandenkolk e, finalmente, os presos durante o estado de sítio. Argumentou que as prisões dos integrantes dos dois primeiros grupos eram inteiramente ilegais e aduziu, em defesa do terceiro grupo, que o estado de sítio não havia respeitado as condições essenciais de constitucionalidade, que o STF era o órgão competente para julgar esta questão e que, findo o estado de sítio, 
começaria para os detidos o direito de julgamento segundo as normas correntes do processo penal (BARBOSA, 1893)

O relator foi o ministro Barradas, que se manifestou contrário à concessão da ordem, sendo seguido por todos os demais, vencido apenas o ministro Pisa e Almeida. O acórdão, publicado em 27.04.1982, foi sucinto e se baseava na incompetência do Judiciário para apreciar, antes do juízo político do Congresso, a constitucionalidade do decreto de estado de sítio durante o recesso parlamentar. Na fundamentação, constava que não era “da índole do STF envolver-se nas funções políticas do Poder Executivo ou Legislativo” e que:

Ainda quando na situação criada pelo estado de sítio, estejam ou possam estar envolvidos alguns direitos individuais, esta circunstância não habilita o Poder Judicial a intervir para nulificar as medidas de segurança decretadas pelo Presidente da República, visto ser impossível isolar esses direitos da questão política, que os envolve e compreende, salvo se unicamente tratar-se de punir os abusos dos agentes subalternos na execução das mesmas medidas, porque a esses agentes não se estende a necessidade do voto político do Congresso. (RODRIGUES, 1991, p.22).

O fato de as prisões terem sido decretadas antes ou depois do estado de sítio não teria relevância porque foram determinadas “dentro dele”. Além disso, embora cessado o estado de sítio, as medidas tomadas deveriam subsistir enquanto os acusados não fossem submetidos ao tribunal competente, pois, do contrário, poderiam se tornar inúteis as providências tomadas por razões de ordem pública.

O voto vencido do ministro Pisa e Almeida, mais extenso que o acórdão, defendia a competência do STF para apreciar a questão, uma vez que já havia cessado o estado de sítio $^{31}$ e que a suspensão das garantias por tempo indeterminado era uma violência que não poderia ser admitida.

\footnotetext{
${ }^{31}$ Segundo o ministro: "Nesta concessão estão incluídos os cidadãos presos durante o estado de sítio, porquanto a competência do tribunal para isso firma-se no seu regimento interno, que no art. 65 , $\S 3^{\circ}$ assim dispõe - 'O tribunal se declarará incompetente para conceder a ordem... se a coação proceder de autoridade militar, no exercício privativo de suas atribuições contra outro militar ou cidadão sujeito no regímen militar (Dec. n. 848 de 11 de outubro de 1890, art. 47), ou se tratar-se de medida de repressão autorizada pelo art. 80 da Constituição, enquanto perdurar o estado de sítio', - donde se deduz a contrario sensu sua competência para tomar conhecimento dela, quando tiver cessado o mesmo estado de sítio; e esta é a hipótese dos autos. O art. 80 da Constituição depende da lei regulamentar, que ainda não foi feita, mas parece-me que não pode ter outra inteligência senão a que meu voto exprime, e em apoio do qual chamarei a Constituição do Império, e os diversos atos dos poderes legislativo e executivo daquele tempo, suspendendo as garantias constitucionais.”. Disponível em: $<$ http://www.stf.jus.br/portal/cms/verTexto.asp?servico=sobreStfConhecaStfJulgamentoHistorico \&pagina=hc300>. Acesso em: 07 jul. 2016.
} 
Em razão de sua grande visibilidade, este caso trouxe um aspecto curioso: nos dias que se sucederam ao julgamento, vários artigos foram publicados em jornais, acusando ou defendo o acórdão que não concedera a ordem aos pacientes. Rui Barbosa publicou 22 artigos criticando a decisão e o próprio ministro Barradas saiu em defesa do acórdão na imprensa, terminando por dizer que, se tivesse escutado apenas a voz do coração, a decisão teria sido outra (RODRIGUES, 1991). O líder governista Aristides Lobo publicou artigo elogiando o acórdão, ressaltando que o STF manteve o direito e a lei, "resguardando-se de um conflito cego em que o executivo não podia, nem devia ceder”. Em oposição ao resultado do julgamento, o deputado Augusto Freitas, em discurso apresentado na Câmara dos Deputados, sustentou que, diante da negativa da ordem no habeas corpus, a garantia única da nação, agora, era o Poder Legislativo (RODRIGUES, 1991).

Percebe-se, a partir deste episódio, a busca por suporte da opinião pública tanto por parte daqueles que pretendiam criticar a posição da corte, quanto do próprio ministro relator que entendeu ser importante, para garantia da legitimidade da atuação do STF, a defesa das razões de julgamento fora do ambiente do tribunal. O debate sobre os fundamentos do julgado foi amplo e tratado não como estritamente jurídico, abordando-se, nele, os possíveis papéis que o Supremo poderia assumir no jogo institucional. A atuação da corte não foi contramajoritária e revelava intenção de se abster do conflito político.

\subsubsection{2.}

HC para os presos do Vapor Júpiter (HC n406, 410 e 415)

Os habeas corpus $\mathrm{n}^{\circ}$ 406, 410 e 415 foram novamente impetrados por Rui Barbosa em defesa do senador almirante Eduardo Wandenkolk e outros, mas, desta vez, envolviam os acontecimentos ligados a tomada do Vapor Júpiter. O Almirante teria assumido o comando do navio, no litoral ao sul do Brasil, com a conivência de oficiais e tripulantes, em tentativa de conspiração, reforçando objetivos da Revolução Federalista iniciada no Rio Grande do Sul. Seus planos foram frustrados pelas forças do governo e Wandenkolk acabou preso e mantido 
incomunicável na fortaleza de Santa Cruz, juntamente com outros civis e militares, que também estavam a bordo do navio.

O primeiro habeas corpus foi impetrado em favor dos presos civis e se baseava, essencialmente, em três pontos: a ausência de notificação de culpa, o excesso de prazo da prisão e a incompetência da autoridade de quem emanou a ordem.

O HC foi distribuído ao ministro Barros Pimentel, que incluiu o caso na pauta de julgamento do dia 02.08.1893. Por 7 votos contra 3, vencido o relator, o STF reconheceu sua competência originária para conhecer do habeas corpus e mandou expedir ordem aos comandantes das fortalezas, por intermédio do Ministério da Guerra, para apresentarem os 48 presos ao tribunal na sessão de 9 de agosto.

No dia marcado, o julgamento teve início sem que os pacientes tivessem sido entregues. Em acórdão curto, resolveu o STF por conceder a ordem de soltura em favor dos detidos, considerando ilegal a prisão, já que os fatos imputados não configurariam crime militar, restando vencido apenas o ministro Faria Lemos (Rodrigues, 1991).

Postos em liberdade os pacientes, o tribunal recebeu ofício assinado pelo Ministro da Guerra, Antônio Enéias Galvão, em que afirmava que o VicePresidente da República resolvera mandar imediatamente soltar os paisanos aprisionados a bordo do Júpiter, entendendo assim “dar mais uma prova de consideração ao órgão superior da Justiça Federal”, mas que ele lamentava que a decisão "não fosse fundamentada, apesar de envolver graves questões de ordem pública, e de surpreendente impugnação das leis aplicáveis”. E continuava dizendo que respeitava os motivos pelos quais a sentença se limitou a declarar ilegal a conservação da prisão, visto que os crimes imputados não ensejavam o foro militar, mas que não tinha entendido a razão pela qual "não tendo o Supremo Tribunal Federal reconhecido a ilegalidade da prisão preferira ordenar a soltura dos presos a designar o juiz a quem deveriam ser remetidos”. Em seguida, afirmava:

Nada diria sobre o silêncio guardado pela sentença a respeito dos fatos e das razões de convicção, se não pudesse inferir que estão revogados o art. 47 do decreto $\mathrm{n}^{\circ}$ 848, de 11 de outubro de 1890, e o art. 190 do Código Penal da 
Armada, invocados no ofício que vos dirigi com data de 8 do corrente (Rodrigues, 1991, p.34).

Ciente do conteúdo do ofício, os ministros do STF se reuniram para elaborar sua estratégia diante daquilo que foi considerado "uma intenção inconcebível de avassalamento do Tribunal ao Poder Executivo”. O ministro Macedo Soares propôs a seguinte redação para um ofício de resposta a ser dirigido ao Chefe de Governo:

O STF que no exercício de suas atribuições constitucionais é tão independente como o Presidente da República, trata convosco de igual para igual: não recebe instruções dos vossos secretários, não admite censura oficial das suas decisões e devolve ao vosso Ministro o seu ofício, confiando que lhes façais sentir a inconveniência de seu procedimento, e crendo, como crê, que o não autorizastes (Rodrigues, 1991, p.35).

Ao final, porém, os ministros rejeitaram a proposta de Macedo Soares e optaram por não tomar conhecimento da matéria do ofício do Ministro da Guerra, não tendo havido, portanto, resposta oficial da corte.

No dia 12 de agosto, foi julgado o $\mathrm{HC}$ n410 em favor de Mário Aurélio da Silveira, imediato civil do Vapor Júpiter, tendo sido concedida a ordem por maioria de votos. Neste acórdão, os ministros decidiram por declarar a inconstitucionalidade do Código Penal da Armada, de 07.03.1891, no qual se baseavam as prisões ${ }^{32}$, decidindo por aplicar ao caso em tela as disposições do Código Penal comum e as leis militares ainda em vigor.

Esclareceu-se que, sendo o paciente imediato civil, a ele não se aplicava a exceção prevista no art.47 do Decreto $n^{0} 848$, de 11/10/1890, que vedava a concessão de HC quando a prisão fosse decretada por autoridade militar, nos

${ }^{32}$ A fundamentação para a inconstitucionalidade foi a seguinte: “ Considerando (...) Que, para firmar-se a competência do foro da Marinha, não podem ser invocadas as regras estabelecidas no Código Penal da Armada de 7 de março de 1891; porquanto o dito Código se funda no Decreto de fevereiro do mesmo ano que autorizou o Ministério da Marinha a reformar o primeiro Código da Armada de 5 de novembro de 1890, e uma tal autorização não tendo sido utilizada, durante o período do Governo Provisório e ditatorial, não podia mais sê-lo, como aliás o foi, no período constitucional;

Que, com efeito, o artigo 83 da Constituição manda somente vigorar as leis anteriores que forem compatíveis com o novo regimen e, sendo um dos princípios fundamentais da ordem constitucional a separação dos poderes e a privativa competência do Congresso para legislar, a autorização legislativa contida naquele Decreto caducou, ex-vi da promulgação da Constituição, faltando assim ao Código de 7 de março toda a base legal; (...)” (Supremo Tribunal Federal, Habeas corpus $\mathrm{n}^{\circ} \quad 410.4$ Disponível $<$ http://www.stf.jus.br/arquivo/cms/sobreStfConhecaStfJulgamentoHistorico/anexo/HC410.pdf > . Acesso em: 10 mai. 2017) 
casos de jurisdição restrita militar e contra militares ou civis submetidos ao regimento interno, concluindo:

Que, finalmente, a prisão militar e a incompetência de foro onde o paciente responde constitui constrangimento ilegal, nos termos do artigo $353 \S \S 3^{\circ}$ e $4^{\circ}$ e do art. 18 da lei de 20 setembro de 1871; e têm, portanto cabimento o habeas corpus conforme o preceito do art. 72, § 23 da Constituição, que manda dar sempre que alguém sofrer ou estiver em iminente perigo de sofrer coação ilegal.

Vale assinalar que, embora o STF tenha optado por não tomar conhecimento do ofício do Ministro da Guerra, ao julgar o HC 410, fundamentou seu acórdão de forma a responder os pontos levantados naquele ofício, ou seja, apresentou as razões para negar validade ao Código Penal da Armada e esclareceu por que o art.47 do Decreto n848 não seria aplicável ao caso concreto. É que o referido ofício, mesmo sendo criticável do ponto de vista do tom de censura assumido, levantou questões que, de fato, eram pertinentes. Afinal, era natural que se exigisse que o STF, ainda debutante em suas funções de jurisdição constitucional, se preocupasse em, ao julgar um caso de grande repercussão, apresentar uma fundamentação convincente para a opinião pública e para dos demais órgãos de Estado. Naquele momento, a correlação de forças políticas ainda estava sendo testada, com clara defasagem para o tribunal, e o recado dado pelo Ministro da Guerra foi de que o preço de ter a vigência de atos normativos questionada era alto, logo, era preciso que o STF fosse zeloso ao decidir pela não aplicabilidade de uma lei. Assim, o ofício não representava, simplesmente, um ato de intimidação da corte pela força, mas dialogava com ela, apresentando argumentos razoáveis para o questionamento da decisão. Na realidade, havia ali uma cobrança pelas fontes da legitimidade da jurisdição constitucional, que, mesmo que realizada através de mecanismo sem previsão formal na legislação, surtiu seu efeito como reação política a decisões judiciais.

Conflitos como o acima relatado nos ajudam a refletir sobre a questão da dificuldade contramajoritária e também sobre a viabilidade de diálogos institucionais. Se, por um lado, o encaminhamento do ofício pelo Ministro da Guerra poderia ser tido como uma tentativa de constrangimento da corte, acabando por ferir sua independência, por outro, não há por que negar aos demais atores institucionais a possibilidade de interlocução, em igualdade de condições, 
sobre as questões de direito. Do contrário, conferindo-se ao tribunal o monopólio absoluto do discurso jurídico, este se vê livre para avançar sobre assuntos antes afetos apenas à política partidária sem que, em contrapartida, veja suas próprias práticas ganhando destaque na discussão da institucionalidade democrática.

Nesse ponto, vale trazer à baila a reflexão de Fernando Ângelo Leal (2017) sobre os impasses para o desenvolvimento de diálogos institucionais, que pressuporiam uma interação dos participantes como iguais e uma predisposição das partes envolvidas para serem persuadidas pelo melhor argumento. Para este autor, um primeiro óbice à satisfação dessas condições diz respeito à posição do tribunal constitucional como detentor do monopólio da última palavra sobre o sentido da Constituição: "Igualdade na participação pressupõe a inexistência de hierarquias, sejam ela definidas explicitamente pelo desenho constitucional, sejam elas construídas a partir do modo como uma instituição entende o seu papel em uma democracia constitucional”.

Dando prosseguimento aos procedimentos necessários para o julgamento do Senador Almirante Eduardo Wandenkolk, em 28.08.1893, o Senado concedeu licença para que fosse ele processado, exigindo, contudo, que fosse pela jurisdição civil e não submetido ao conselho de guerra, negando, nesse ponto, o pedido formulado em mensagem presidencial anterior (que requeria autorização para processá-lo perante à Justiça Militar). Observe-se que, neste momento, tanto o Presidente da República quanto o Senado pretendiam fazer valer suas posições quanto à competência jurisdicional para apreciação do caso.

Rui Barbosa, então, impetrou o $\mathrm{HC} \mathrm{n}^{\circ} 415$ em favor do Almirante e mais dois militares envolvidos no incidente. Segundo relato de Leda Boechat Rodrigues (1991), a sessão de julgamento teve início debaixo de ameaças de dissolução da corte caso a ordem fosse concedida. O pedido foi julgado improcedente por maioria de votos, tendo restado vencidos os ministros José Higino, Pisa e Almeida e Pereira Franco.

Os argumentos para a negativa da ordem foram de que, para o Almirante Eduardo Wandenkolk, a demora na formação de culpa adveio da observância do art.20 da Carta Política de 1891, que exigia a prévia licença do Senado para autorização do prosseguimento do sumário de culpa e que, só depois desta deliberação política, teria início o prazo prefixado em lei para conclusão do 
processo. Quanto aos demais pacientes, entendeu-se que os oficiais reformados ainda eram considerados praças alistadas no exército, sujeitos, portanto, à jurisdição militar. Na hipótese, estariam reunidos os dois requisitos legais: natureza militar do crime e agente militar, prevalecendo, portanto, o disposto no art.47 do Decreto $\mathrm{n}^{\circ}$ 848, que vedava a concessão de habeas corpus. O ministro Macedo Soares, em seu voto, fez questão de pontuar que o Senado havia exorbitado de suas atribuições ao deliberar sobre competência do juízo civil para apreciação do caso ${ }^{33}$.

Os votos vencidos defendiam que não houve autorização do Congresso Nacional para a prisão do Senador e que não seria hipótese de flagrância dada a ausência do respectivo auto. Além disso, os militares reformados retornam à vida civil, sendo a justiça comum a competente para julgá-los por delitos fora do exercício de função militar.

Quanto ao incidente da fixação de competência, Rui Barbosa viria a se manifestar de forma contraditória: na petição inicial do habeas corpus e, em discurso proferido em 26.08.1893, defenderia que era prerrogativa do Senado deliberar sobre a competência de foro, já que o art.20 da Constituição de 1891 havia autorizado que a casa legislativa respectiva avaliasse a existência de flagrância e de crime inafiançável, o que seria inseparável da conclusão sobre a jurisdição competente. Constituiria, portanto, uma faculdade implícita concedida pelo mencionado art.20, não cabendo ao intérprete restringir onde a lei não o fez. O Senado, ao reconhecer a competência do foro civil, não teria manifestado mera opinião, mas exercido sua atribuição que o próprio governo reconhecera ao requerer que o processo corresse perante a Justiça Militar. Depois, ainda no discurso de 26.08.1893, corrigiu sua posição para criticar o rito assumido pelo procedimento, afirmando que não cabia ao Presidente requerer autorização ao

\footnotetext{
${ }^{33}$ Nas palavras do ministro: "Nem obsta a opinião do Senado, manifestada pela discussão e votação na sessão de 29 de agosto último (documento fls. 9 a 11), que é civil o foro onde devem responder os pacientes. Porquanto, é regra do direito formal que cada juiz ou tribunal é o único competente para conhecer da sua jurisdição, firmando-a a ou dela declinando, e, em ambas as hipóteses, abrindo lugar a recursos, já ordinários, já extraordinários, como os conflitos, positivos ou negativos de jurisdição, com devolução para o superior legítimo. Indicar competência alheia foi exorbitância do Senado; e bastava que o juiz civil por ele indicado, em contraposição ao político ou ao militar, se desse por incompetente, para que frustradas ficassem as conseqüências da sua deliberação.” (Disponível em: $<$ http://www.stf.jus.br/portal/cms/verTexto.asp?servico=sobreStfConhecaStfJulgamentoHistorico \&pagina $=$ hc415>. Acesso em: 08 jul. 2016)
} 
Senado, o que seria incumbência da autoridade processante, e que mensagem presidencial continha "bagagem inoportuna de teses jurídicas”. Nessa linha, conclui que, se o Ministério Público tivesse revestido "da energia essencial ao desempenho de suas altas funções” já teria instaurado o processo e a questão da competência seria decidida pelo Judiciário, chegando “desembaraçada assim completamente das correntes políticas” ao Senado ${ }^{34}$.

As opiniões de Rui Barbosa transcritas demonstram que a forma jurídica se amoldava perfeitamente às duas teses defendidas: era possível construir uma argumentação perfeitamente lógica em defesa da força e da legitimidade da decisão do Senado sobre a competência de foro, bem como era viável argumentar que a análise do Judiciário sobre a fixação do órgão jurisdicional competente deveria ter ocorrido primeiro, evitando-se, assim, um juízo político sobre a questão. A utilização de teses jurídicas pelo Legislativo ou pelo Executivo poderia ou não ser condenável a depender de em que lado da controvérsia se colocavam e não porque, de fato, seria vedado a eles se expressar na dicção do direito. Ou seja, o embate entre os poderes começava já ao se arbitrar quem possuiria a prerrogativa de se manifestar em termos jurídicos, supostamente superiores aos termos políticos.

Episódios como este ajudam a revelar que o discurso jurídico, por si só, se manifesta como um instrumento de poder, disputado pelas forças em conflito. Ao reagir veementemente quando os outros Poderes pretendiam se expressar nesta linguagem, a corte trabalha para se diferenciar e se fortalecer, afirmando um âmbito de atuação próprio, que seria infenso às investidas externas dos órgãos desprovidos do saber técnico.

Por fim, vale mencionar que, em 1894, foi impetrado o $\mathrm{HC} \mathrm{n}^{\circ} 604$ em favor do capitão-tenente Huet Barcelar, preso juntamente com Eduardo Wandenkolk e também paciente do $\mathrm{HC} \mathrm{n}^{\circ} 415$ datado do ano anterior. Desta vez, o STF entendeu que, sendo ele militar reformado, não poderia ser submetido à jurisdição militar, mas sim à comum, concedendo a ordem. O governo, contudo, não viu com bons olhos a mudança de jurisprudência e se recusou a cumprir a decisão. O tribunal, 
então, oficiou o Procurador da República, que, em resposta, apontou a incongruência da corte e afirmou que o governo procedeu de boa-fé ao negar cumprimento ao julgado.

Posteriormente, o Supremo viria a afirmar, no bojo do julgamento do HC nº12/1895, que o ato do Poder Executivo que se nega a cumprir decisão judicial viola a Constituição, ainda que esta decisão esteja "em desacordo com a jurisprudência uniforme, constante e quase secular de que faz menção o Acórdão de 2 de setembro de 1893” (Rodrigues, 1991).

Se tomarmos ativismo na concepção do juiz que não adere a padrões de julgamento, o caso acima citado seria uma hipótese em que o Poder Executivo reagiu a uma postura ativista da corte, negando-se a aceitá-la.

\subsubsection{3.}

\section{HC n' 1063 e 1073}

O HC nº1063 foi impetrado por Rui Barbosa em favor do senador João Cordeiro, dos deputados Alcindo Guanabara e Alexandre J. Barbosa Lima, bem como do major Thomaz Cavalcanti de Albuquerque, e de Frederico José de Sant’Anna Nery e José de Albuquerque Maranhão. Os pacientes eram acusados de participar de conspiração para o assassinato do Presidente Floriano Peixoto, que havia sofrido atentado em 05.10.1897. Diante da comoção gerada pelo incidente, o Congresso Nacional havia aprovado, em 12.11.1897, o Decreto $\mathrm{n}^{\circ} 456$ para declarar estado de sítio por 30 dias. Neste mesmo dia 12, a trama vinha a ser descoberta, sendo os acusados presos e desterrados para o presídio de Fernando de Noronha.

O principal argumento em defesa dos pacientes era a limitação dos efeitos do estado de sítio: a Constituição teria determinado que o governo só poderia prender e desterrar durante o período designado no decreto, não sendo lícito dilatar, após cessado este prazo, as medidas coercitivas.

A ordem foi negada por 5 votos a 4, tendo a posição vencedora se baseado na alegação de que competiria apenas ao Congresso o exame das providências tomadas pelo chefe do Poder Executivo durante o estado de sítio. 
No dia seguinte, o jornal O Debate comemorava que estaria, finalmente, firmada a jurisprudência sobre a figura jurídica do art.80, da Constituição republicana, já que a suspensão das garantias fundamentais determinada pelo Executivo não podia ficar à mercê do Poder Judiciário. A publicação ainda afirmava que se a ordem tivesse sido concedida, o governo a cumpriria (RODRIGUES, 1991).

Entretanto, apenas uma semana depois, julgando o HC 1073, o STF daria sinais de que, ao contrário do que supunha o jornal, não havia jurisprudência consolidada sobre o tema. Apesar da denegação da ordem anterior, o governo já havia mandado soltar Sant'Anna Nery e Tomás Cavalcanti. O HC, então, foi impetrado em favor dos demais pacientes.

Com a mesma composição da sessão anterior, foi concedida a ordem, por maioria, para apresentação dos pacientes e prestação de esclarecimentos pelo governo, ficando marcada a sessão do dia 16 de abril para julgamento. Na data aprazada, os ministros, por maioria de 8 votos, determinaram a soltura dos presos, reconhecendo que as imunidades parlamentares não se suspendem com o estado de sítio.

O ministro Macedo Soares, em seu voto, se mostrou preocupado em defender a corte das acusações de formar jurisprudência incoerente:

Nem igualmente tem procedência, nem sequer senso comum, a argüição feita ao Supremo Tribunal Federal por não guardar coerência com os seus anteriores acórdãos, que a ignorância ou a má fé enfaticamente crisma de arestos, como se este ou qualquer outro tribunal pudesse formar e firmar arestos porque quer, como quer ou quando quer. O aresto é um produto espontâneo, inconsciente, da elaboração mental de juízes que, nutridos de idéias e princípios, regras e praxes anteriormente apreendidos ou formados por estudos de ocasião, reúnem-se, concentram-se, acordam, sem concerto prévio, no julgar sempre da mesma maneira, perpétua e semelhantemente, os casos submetidos ao seu conhecimento. É esse consenso espontâneo, não prevenido, nem constrangido, não proposital, nem ocasional, insciente de acordo deliberado, o que constitui o aresto, cuja noção exata foi perfeitamente definida, há séculos, pelo jurisconsulto romano Callistratus, na L. 38 D. de Legibus: (...)

(...)

Eis aí o aresto: res perpetuo similiter judicata: o caso julgado sempre na mesma conformidade. Ora, para o primeiro elemento do aresto, perpetuo, falta ao Supremo Tribunal Federal a idade, pois, tendo começado a funcionar em 1891, há sete anos apenas, só teve de decidir sobre estado de sítio em três períodos, a saber: 1892, para reprimir a revolta chamada "dos treze generais"; 1894, para subjugar a revolta da armada, tendente à restauração da monarquia; 1897, para poder o chefe de polícia fazer inquérito acerca de crimes comuns cometidos nesta 
cidade em março e novembro (!). Bem poucos foram os habeas corpus impetrados nessas três épocas e assim bem poucas as decisões do tribunal, concedendo-os ou negando-os. Onde as res perpetuo judicatae, que tenham formado e firmado aresto? Quanto ao elemento similiter, é tão raro dar-se uniformidade de opiniões em corpos coletivos, cujo pessoal constantemente se renova, que isto só explica a raridade dos arestos, isto é, das sentenças cuja autoridade obtenha força de lei, e o grande número de decisões que a não merecem por não serem uniformes. E cabe já aqui observar que em duas causas idênticas, entre as mesmas partes, patrocinadas pelos mesmos advogados, pode o juiz decidir em uma sim e na outra não, porque julga pelo alegado e provado. Ora, basta que em uma das causas tenha-se o patrono descuidado de dar a prova que exibiu na outra.

O ministro Ribeiro de Almeida, voto vencido, defendeu que não caberia um segundo habeas corpus com base nos mesmos fatos e que o julgamento do HC $\mathrm{n}^{\circ} 1063$ teria feito coisa julgada.

Este episódio suscitou resposta oficial do Presidente da República que, apesar de cumprir o acórdão, encaminhou mensagem ao Congresso Nacional criticando severamente os fundamentos da decisão:

O novo pedido de habeas corpus, sob qualquer fundamento, era simplesmente impertinente.

Dessa vez, porém, assim não pareceu à maioria do STF, que rompendo com todos os precedentes, concedeu por Acórdão de 16 de abril, a ordem impetrada, e restituiu a liberdade os indivíduos cuja presença aqui o Governo considerava perigosa à ordem pública.

Não dissimulo que foi grande a minha decepção vendo a ação do Poder judiciário contrapor-se desta sorte aos efeitos de uma medida que o Governo reputava indispensável, como garantia da ordem e, além disso, apoiada nas decisões anteriores do próprio STF.

Essa decisão, ferindo o art.80 da Constituição, abalou a harmonia indispensável entre os Poderes, que a mesma Constituição criou como órgãos da soberania nacional, já exercendo atribuição conferida privativamente ao Congresso, já inutilizando, antes do julgamento deste e nas vésperas de sua reunião, as providências repressivas reputadas necessárias pelo Executivo, a bem da manutenção da ordem.

Como era fácil de prever, semelhante decisão, influenciada pela paixão partidária, animou e aumentou a ousadia dos perturbadores da ordem (Rodrigues, 1991).

No âmbito do Supremo, a mensagem repercutiu na sessão de 04.05.1898. O ministro Américo Lobo suscitou o tema, apoiando os argumentos apresentados pelo Presidente e defendendo a necessidade de reforma da legislação criminal. Ao ouvi-lo, o ministro Lúcio Mendonça reagiu energicamente, afirmando que 
mencionar aquele tópico era descortês, não só pela censura por incoerência que sofria o STF, mas porque o conteúdo da mensagem era inepto ao "insinuar que uma lei ordinária, de interpretação constitucional, podia determinar a obrigatoriedade de inteligência oposta à do Supremo Tribunal Federal, tão autorizado e competente intérprete da Constituição como o próprio poder legislativo” (RODRIGUES, 1991, p.122).

O incidente deu azo a editoriais e artigos na imprensa, sendo que o jornal O Debate criticava o fato de o ministro Lúcio Mendonça ter se mostrado tão melindrado com a mensagem presidencial, alegando que não era ofensa aludir à incoerência de certos julgamentos "que tiveram no seio daquele Tribunal os mesmos característicos e sorte diversa, ao sabor das paixões do momento" (RODRIGUES, 1991, p.123).

Mesmo não havendo obrigação legal de respeito aos precedentes, a oscilação tão grosseira da jurisprudência gerou reação do Executivo e da opinião pública, que passou um recado de censura ao tribunal, em uma tentativa de fixar limites à atuação da corte. Por outro lado, taxar de descortesia a crítica recebida revelava intenção de retirar a questão de qualquer crivo público, como se, o simples fato de discuti-la, representasse ameaça indevida aos poderes do STF.

\subsection{2.}

\section{A Revolução de 1930 e o Estado Novo}

Em 1930, inaugura-se no Brasil uma nova fase, marcada pelo fim do arranjo oligárquico da República Velha e caracterizada por um modelo político autoritário. Na análise de Boris Fausto (1997), esta inclinação autoritária se devia em parte às convicções de Getúlio Vargas, assim como às dos integrantes da cúpula das Forças Armadas que ganharam espaço no governo a partir de 30, além de poder ser atribuída à crise de 1929, que parecia demonstrar a falência de um certo tipo de capitalismo associado ao livre mercado e à democracia liberal.

Logo de início, o STF sofreria fortes revezes: o Governo Provisório diminuiria os vencimentos dos ministros e, através do Decreto $n^{0} 19.656$, de 03 de fevereiro de 1931, reduziria de 15 para o 11 o número de ministros. Logo em 
seguida, o Decreto $\mathrm{n}^{0} 19.711$, de 18.02.1931, aposentaria os ministros Godofredo Cunha, Edmundo Muniz Barreto, Antonio C. Pires e Albuquerque, Pedro Affonso Mibieli, Pedro dos Santos e Geminiano da Franca.

O Decreto n $^{\circ} 19.398$, de 11 de novembro de 1931, por sua vez, dissolveria o Congresso Nacional e as Assembleias estaduais, suspenderia as garantias constitucionais e a apreciação judicial dos atos do governo, impondo, ainda, a intervenção nos estados. O habeas corpus seria mantido, mas sob condição de não amparar crimes funcionais e da competência de tribunais especiais. Este Decreto se tornaria a verdadeira lei fundamental do país até a promulgação da Constituição de 1934.

O ano de 1932 marcou o fortalecimento das mobilizações pela reconstitucionalização e, para responder a estes reclamos, Getúlio editou o Decreto $\mathrm{n}^{021.076}$, de 03 de fevereiro, o primeiro Código Eleitoral nacional do Brasil. Entretanto, a adoção desta medida não teria sido suficiente para conter as agitações e a exigência por uma nova Constituição crescia. Neste clima, foi convocada a Constituinte de 1933, dando início a um breve período de redemocratização. A Constituição de 1934 incorporaria direitos sociais na esteira do novo constitucionalismo que começara a se afirmar com as Constituições mexicana de 1917 e de Weimar de 1919. Na visão de Adriano Pilatti:

Inovadora e sintonizada com as ideias e desafios de sua época, a Constituição de 1934 permanece como um paradoxo. Por um lado, foi nossa Constituição democrática de vida mais breve; derrogada formalmente em 1937, já havia sido ferida de morte comas Emendas $\mathrm{n}^{\circ} 1, \mathrm{n}^{\circ} 2$ e n ${ }^{\circ} 3$, de 18 de dezembro de 1935, que sob o clima de comoção e apreensão decorrentes da chamada "Intentona Comunista" - permitiram à Câmara e ao Senado autorizarem o presidente a declarar "comoção intestina grave”, equiparando-a ao Estado de Guerra. Com isso, o presidente poderia suspender garantias individuais, demitir funcionários civis e reformar oficiais militares implicados "em movimento subversivo". Por outro lado, a Constituição social-democrática de 1934 definiu uma estrutura e um repertório de conteúdos constitucionais dos quais nem as Constituições legítimas nem as Cartas outorgadas posteriores se distanciaram de todo. A rigor, desde 1937 e até 1988, o que temos tido são versões melhoradas ou pioradas, autocráticas ou mais democráticas da Constituição de 16 de julho, sendo a vigente Constituição Cidadã a melhor de todas as versões, incluindo a original. (2008, p.73/74)

Como mencionado na citação acima, o período de redemocratização teve vida curta. A medida de exceção decretada por Vargas, amparada nas Emendas 
Constitucionais $\mathrm{n}^{0} 1$, 2 e 3 , desencadeou a violência repressiva policial e, em 11.11.1936, a Lei ${ }^{0} 244$ criou o Tribunal de Segurança Nacional como órgão da Justiça Militar, com juízes escolhidos livremente pelo Presidente da República, destinado a julgar crimes políticos e de subversão. Mesmo perseguidos e neutralizados, os comunistas serviriam de pretexto para o golpe de 1937, cuja motivação verdadeira estava mais relacionada a onda de conspirações intraoligárquicas em torno da sucessão presidencial (Pilatti, 2008).

Posteriormente, a Constituição de 1937 viria a extinguir as Justiças Federal e Eleitoral e a constitucionalizar a existência do Tribunal de Segurança Nacional. Além disso, reduziria a idade compulsória de aposentadoria de 75 para 68 anos (art.91, “a”), gerando a saída dos ministros do Supremo Tribunal Federal Edmundo Lins, Hermenegildo de Barros e Ataulfo de Paiva. Pouco tempo depois, outros dois ministros acabariam tendo que se aposentar compulsoriamente, Cândido Mota e Carlos Maximiliano, ao atingirem a nova idade limite fixada.

No que compete ao controle de constitucionalidade, determinaria que a declaração de inconstitucionalidade pelo Judiciário perderia o efeito se o Presidente voltasse a submeter a lei ao Parlamento e este a aprovasse novamente pelo quórum de dois terços (art.96).

Nota-se, portanto, que o clima político-institucional não favorecia o florescimento da independência da STF, sendo que, de uma maneira geral, este tribunal não representou obstáculo para a política de maior intervenção na economia adotada pelo governo, revelando, também, postura contida na defesa dos direitos e garantias individuais. Vale mencionar que o texto da Constituição de 1934 passou a prever o instrumento do mandado de segurança, o que, em tese, aumentaria o rol de instrumentos hábeis a levar até o Judiciário a apreciação e a defesa de direitos violados por atos de autoridade pública ${ }^{35}$, mas, na prática, dada a conjuntura política, esta previsão não representou ganho em termos de preservação de liberdades e garantias fundamentais.

\footnotetext{
35 Posteriormente, com a Constituição de 1937, esta ação deixou de ser um remédio previsto constitucionalmente, mas continuou em vigor com base no art. 16 do Decreto-lei $n^{0}$ 06, de 16.11.1937, ainda que submetido a várias restrições.
} 


\subsubsection{1.}

MS n' 111

Em 11.07.1935, foi editado o Decreto $\mathrm{n}^{0} 229$ que determinava o fechamento da Aliança Nacional Libertadora (ANL), pelo prazo de 6 meses, por estar desenvolvendo atividade subversiva da ordem política e social, ressalvando que deveria ser promovida, sem demora, ação judicial para o cancelamento de seu registro civil.

O mandado de segurança $\mathrm{n}^{\circ} 111$ foi impetrado pelo presidente da Aliança, comandante Hercolino Cascardo, para fazer valer o direito líquido e certo de funcionamento daquela entidade, já que o art.113, nº 12, da Constituição de 1934, garantia a liberdade de associação e determinava que a dissolução da entidade só poderia ocorrer por meio de sentença judicial.

O fechamento, por sua vez, se baseava na Lei n³8/1935 que autorizava o governo a fazê-lo, pelo prazo de 6 meses, nas hipóteses de a associação civil ter adquirido personalidade jurídica mediante falsa declaração de seus fins, ou de, depois de registrada, ter passado a exercer atividade subversiva da ordem política ou social, devendo, entretanto, ser proposta ação judicial para decidir sobre a dissolução.

Afastadas as preliminares por maioria, o acórdão unânime foi pelo indeferimento da ordem nos termos do voto do relator, que se satisfez com a informação prestada pelo Governo de que a ANL tinha sido constituída para a subversão da organização social e para a mudança do regime. Essa informação, segundo ele, de acordo com a "jurisprudência tranquila formada em casos análogos” produzia presunção juris tantum de veracidade, não ilidida pela parte contrária. A Lei n³8 seria severa, mas sua severidade seria "uma exigência das circunstâncias difíceis com que, então, lutavam os dirigentes de todas as nações cultas.” Como não houve a dissolução, que dependia de sentença judicial, mas apenas o fechamento por 6 meses, não teria ocorrido inconstitucionalidade.

O ministro Costa Manso, endossando as conclusões do relator, foi mais além em seu voto, deixando claro que o Poder Judiciário só deveria analisar a parte extrínseca do ato administrativo: 
O juiz só poderá invalidar o ato ilegal. Da ilegalidade resulta a nulidade. E o ato é nulo quando a autoridade que o expediu seja incompetente, quando não tenham sido observadas as formalidades externas substanciais, e quando a medida não seja, em tese autorizada pela lei.

\section{(...)}

A verificação da justiça, oportunidade e conveniência de medidas administrativas é matéria estranha à função judicial, a menos que tal função seja expressamente conferida ao juiz. Os Poderes Políticos são harmônicos e autônomos. Cada um deles exerce privativamente a função que lhe é distribuída. Quem administra é o Poder Executivo. Não pode o Judiciário intervir como se fora instância administrativa superior, para, assim, influir ou colaborar na administração pública.

Vê-se que o excessivo formalismo adotado, caracterizado pela utilização de categorias que contrapõem a apreciação de legalidade (judicial) e de mérito (administrativo), pode ser encarado como uma estratégia da corte para lidar com o autoritarismo do governo. Esta atuação se encaixaria na concepção de ativismo que se define pelo julgamento orientado pelo resultado, independente do percurso processual. Nesse caso, o resultado desejado seria o de não alteração da realidade fática para não contrariar os interesses dominantes.

\subsubsection{2. $\mathrm{HC} \mathrm{n}^{\circ} \mathbf{2 6 . 1 5 5}$}

Em junho de 1936, Heitor de Lima impetrou o HC n 26.155 em favor de Maria Prestes, cidadã alemã, alegando que a paciente foi recolhida à casa de detenção, estando incomunicável, sob acusação de delitos contra a ordem política e social. O advogado sustentava que ela não havia sido submetida a processo judicial no Brasil e que seu habeas corpus se fundava, justamente, no direito de ser submetida a julgamento perante os tribunais brasileiros, ou seja, de não ser expulsa. Além disso, a paciente estava grávida de 4 meses, devendo ser preservado o direito do nascituro, concebido no Brasil, que seria atingido iniquamente pelo decreto de expulsão. Citava o art.141 da Constituição Federal que determinava ser obrigatório o amparo à maternidade e à infância em todo o território nacional. Prosseguia, ainda, afirmando que o papel da Corte Suprema não seria de análise da conveniência ou da oportunidade da medida coercitiva, mas o de examinar sob o ângulo da legalidade ou da constitucionalidade. No 
processo de expulsão, haveria apenas três depoimentos de investigadores de polícia, ouvidos na ausência da acusada, que se limitaram a informar que a expulsanda era tida por agitadora, constituindo perigo para a segurança nacional.

Participaram do julgamento os ministros Edmundo Lins, Hermenegildo de Barros, Bento de Faria, Eduardo Espínola, Plínio Casado, Carvalho Mourão, Laudo de Camargo, Costa Manso, Octavio Kelly, Ataulfo de Paiva e Carlos Maximiliano e a sessão ocorreu em 17.06.1936.

Em acórdão de uma página, os ministros negaram a requisição dos autos do processo administrativo, o pedido de comparecimento da paciente, bem como a perícia médica que atestaria a alegada gravidez. Por maioria de votos, acolheram a preliminar de que, estando em vigor o estado de comoção intestina equiparada ao estado de guerra do Decreto $\mathrm{n}^{\circ} 702 / 1936$, estava suspensa a garantia constitucional do habeas corpus. Os ministros que votaram vencidos, Eduardo Espíndola, Carvalho Mourão e Carlos Maximiliano, conheciam do HC, mas o indeferiam no mérito.

Aqui, a resposta jurisdicional foi dada sem maiores preocupações com motivações de natureza argumentativa-normativa, limitando-se por resolver a questão de forma afinada aos interesses do Executivo. Em outras palavras, nem houve tentativa de conferir aparente legitimidade discursiva à decisão, que foi proferida de forma extremamente sucinta.

\subsubsection{3.}

\section{HC n² 26.178}

Em novembro de 1935 eclodiu no Rio de Janeiro a rebelião conhecida como Intentona Comunista, que gerou a prisão do Senador Abel Chermont e dos Deputados Federais Abguar Bastos, Domingos Velasco e Otávio Silveira. João Mangabeira impetrou o $\mathrm{HC} \mathrm{n}^{\circ} 26.178$ sustentando que as prisões eram ilegais, já que não tinham sido precedidas de autorização da Câmara e do Senado.

Em sessão ocorrida em 20 de julho de 1936, um mês após o julgamento do HC de Maria Prestes, com extenso voto, o relator, ministro Carvalho Mourão, recorrendo ao direito comparado, à doutrina e à jurisprudência do STF sobre 
habeas corpus, afastou as preliminares de que as imunidades parlamentares e o direito ao habeas corpus estariam suspensos na vigência do estado de sítio, sendo acompanhado pelos demais, restando vencidos os ministros Bento de Faria e

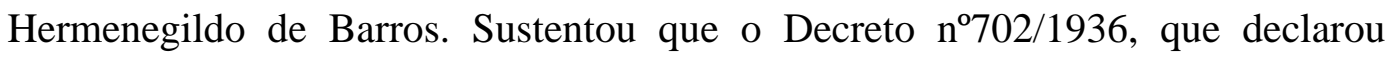
comoção intestina equiparada ao estado de guerra, na realidade, não teria proclamado estado de guerra internacional, que geraria consequências mais sérias, mas sim o estado de sítio agravado de que trataria o art.175, parágrafo 15, da Constituição. Acrescentou que o próprio Presidente da República teria encaminhado mensagem ao Congresso Nacional, afirmando que a medida de exceção autorizada não consistia estado de guerra em sentido próprio, mas em uma equiparação tendente a reforçar os poderes de autoridade na defesa da segurança nacional. Assim, concluiu que o que foi declarado foi o estado de sítio e nunca o estado de guerra. Mas, mesmo em estado de guerra, o que restaria suspenso, de acordo com art. 161 da Constituição Federal, seriam as garantias constitucionais, que são as garantias dos direitos individuais. As imunidades parlamentares não seriam garantias individuais, mas prerrogativas do cargo.

Quanto ao cabimento do remédio constitucional, o relator defendeu que, estando a liberdade de locomoção assegurada, mesmo em estado de guerra, embora sob determinadas condições e com determinadas restrições, é preciso que, sendo ela violada, seja amparada por habeas corpus. Assinalou que:

Não posso compreender que, assegurado um direito, mesmo em estado de guerra, possa ele ser violado sem que caiba recurso protetor. Se, em estado de guerra, a liberdade de locomoção é, ainda que restritamente, protegida até certo ponto, para determinados efeitos, é forçoso que o habeas corpus a ampare e garanta dentro desses precisos limites.

Tal doutrina, aliás, nada tem de novo. É doutrina ortodoxa no direito das democracias, e, sobretudo, na nossa tradicional e inextirpável democracia.

Foi apoiado nessa doutrina que o antigo Supremo Tribunal Federal sempre concedeu habeas corpus em estado de sítio, afim de fazer cessar a incomunicabilidade de presos políticos. O habeas corpus, embora, em geral, não coubesse em tal período anormal, foi concedido sempre que se reconhecia haver o governo excedido os poderes que o próprio estado de sítio lhe outorgava.

No mérito, porém, entendeu que o governo requereu licença para processar os pacientes à Câmara e ao Senado quando estes já estavam presos, logo, quando estas Casas Legislativas deliberaram sobre o processo, o fizeram cientes da prisão, 
sem que tenham requerido a liberdade dos réus. Diante disso, negaram a ordem unanimemente.

É possível notar, assim, a partir dos acórdãos mencionados, que a linha adotada pelo STF neste período era de evitar embates diretos com o Poder Executivo, mesmo que sem a preocupação de construir uma jurisprudência consistente sobre a suspensão das garantias individuais quando vigentes medidas de exceção.

\subsection{3.}

\section{A Constituição de 1946 e a instabilidade política das décadas de $1950 / 1960$}

O fim da Segunda Guerra Mundial, com a vitória dos Aliados sobre a ameaça nazi-fascista, e o próprio desgaste do Estado Novo proporcionaram o início de uma série de medidas liberalizantes a partir da Lei Constitucional nº9, de 28 de fevereiro de 1945, que alteraram significativamente a Constituição de 1937. Na intepretação de Adriano Pilatti (2008), percebendo a inevitabilidade do fim da ditadura, Getúlio tentou sobreviver politicamente a ela, promovendo modificações democratizantes no regime. Ressurgiram os partidos políticos, os presos políticos foram anistiados e foram convocadas eleições federais para o dia 02 de dezembro do mesmo ano, nas quais o general Eurico Gaspar Dutra foi eleito.

Em 18.09.1946, foi promulgada a nova Constituição, que restaurou a Federação, o sistema representativo, o Congresso Nacional com suas funções de fiscalização e controle e as eleições diretas para Presidente da República. A Justiça Eleitoral passou a ser prevista no texto constitucional e a Justiça do Trabalho integrada ao Poder Judiciário. Em matéria de direitos fundamentais, a Carta contemplou não só direitos políticos como também sociais, datando desta época a instituição da garantia da inafastabilidade do controle jurisdicional em face da ameaça a direitos individuais (art.141, parágrafo $4^{\circ}$ ). Com relação ao Supremo Tribunal Federal, o art.98 fixou que seria composto por onze ministros, sendo que tal número poderia ser elevado por lei de iniciativa do próprio tribunal.

Sobre este período, assinala Adriano Pilatti (2008): 
Nos 17 anos e meio que transcorreram entre a promulgação da Constituição de 1946 e o golpe militar-empresarial de 1964, a sociedade brasileira viveu sua primeira experiência democrático-representativa de massa, em um período marcado por intensas mobilizações de classe. O tabuleiro político foi rapidamente dividido em dois campos distintos e antagônicos, nos quais dois projetos contraditórios entre si foram gestados e experimentados. De um lado, o campo trabalhista, nacionalista e reformista, tendo à frente o PTB com Getúlio, primeiro, e Jango depois.

(...)

No campo conservador, articulado partidariamente em torno da UDN, os grupos dominantes se congregavam e se mobilizavam em torno de outro projeto, de integração, subordinada e contida na órbita norte-americana, ao sistema capitalista em processo de transnacionalização - um projeto de neutralização das lutas sociais por direitos e reformas, de restrição ao exercício da cidadania pelos "de baixo", de controle das decisões políticas e econômicas "pelo alto" e para o alto. (PILATTI, 2008, p.85)

Entretanto, como observa Ricardo Augusto dos Santos (2013), este chamado período de redemocratização também foi marcado por medidas de forte repressão conduzidas pelo governo Dutra. Paralelamente a um aumento da participação política popular nos espaços públicos, uma série de restrições limitava a representação das classes baixas na estrutura política: não havia liberdade de organização sindical, o acesso ao voto era restrito, o partido comunista teve seu registro cassado e os protestos despertavam reações veementes das forças policiais ${ }^{36}$.

O STF não teve nenhum protagonismo no desenrolar das crises institucionais das décadas de 1950/1960, sendo interessante citar o episódio do contragolpe promovido pelo General Lott, em que, sendo chamado a se manifestar, o tribunal se viu diante do impasse entre uma solução jurídica e a força dos acontecimentos políticos. Outra situação interessante foi aquela que envolve o julgamento de inconstitucionalidade da Lei $\mathrm{n}^{\circ} 9.790$ por procedimento pouco ortodoxo.

\footnotetext{
${ }^{36}$ O autor assinala que: "À espontaneidade dos movimentos populares, o Governo Dutra, que aparece com demasiada frequência na historiografia como o governo da "União Nacional" e "Pacificação", respondeu com repressão. O mito construído apresenta um governante atento a Constituição [9] mas a democracia burguesa não somente aceitou a repressão como necessitava de instrumentos de exceção para seu governo. Era estratégico a presença e uso da coerção física na ilusória transição conservadora liberal democrática.” (SANTOS, 2013)
} 


\subsubsection{1.}

\section{MS n 3557 e HC $n^{\circ} 33.908$}

Depois do suicídio de Getúlio Vargas em 1954, Café Filho, então vicepresidente, assume a Presidência da República. Em 1955, por razões de saúde, é forçado a se afastar do cargo, assumido por Carlos Luz, presidente da Câmara dos Deputados em 08 de novembro.

O General Lott, ministro da Guerra, temendo por um golpe em andamento - no qual o próprio presidente afastado e o em exercício estariam envolvidos que impediria a posse da chapa formada por Juscelino Kubitschek e João Goulart, eleita em 03.10.1955, decide se engajar no contragolpe. A situação chega ao grau de conflito armado e, aproveitando-se do afastamento de Carlos Luz, que estava a bordo do cruzador Tamandaré, a Câmara dos Deputados reconhece seu impedimento para o exercício do cargo. Nereu Ramos, vice-presidente do Senado, assume e, posteriormente, é negociada uma carta de renúncia de Carlos Luz.

Café Filho se recupera, mas a cúpula militar ligada ao bem-sucedido contragolpe avalia que seu retorno à Presidência da República devolveria a situação à condição de incerteza que se encontrava anteriormente, decidindo por impedir que reassumisse o cargo mesmo após a reabilitação de sua saúde.

Em sessão extraordinária de 21.11.1955, o Congresso Nacional viria a aprovar a Resolução 21/55, que declarava permanecer o impedimento anteriormente reconhecido de Café Filho e, em 25 de novembro, o pedido de estado de sítio encaminhado por Nereu Ramos era aprovado em regime de urgência.

É neste cenário que Café Filho impetra o MS n³557, em 22.11.1955, alegando que, tendo desaparecido o motivo de seu impedimento, deveria retornar ao exercício do cargo.

Inicialmente, os ministros precisavam enfrentar duas preliminares: (i) cabimento de mandado de segurança contra resolução legislativa de caráter político, tese que demandava a análise da possibilidade de apreciação judicial de ato político e a verificação da competência do STF para julgamento de mandado 
de segurança contra ato do Congresso que não fosse emanado das Mesas da Câmara e do Senado, conforme redação do art.101, I, i, da Constituição de 1946; (ii) cabimento do mandado de segurança diante da supressão de garantias instituída pelo art. $2^{\circ}$ da Lei $n^{\circ} 2.654 / 55^{37}$, que decretou o estado de sítio.

O relator, Hahnemann Guimarães, entendeu que, diante da inafastabilidade da apreciação do Judiciário prevista no art.141, parágrafo $4^{\circ}$ da Constituição, o cunho político da resolução não poderia impedir a análise de mérito. Além disso, como o estado de sítio só havia sido decretado em 25.11.1955 e o mandado de segurança foi impetrado em 22.11.1955, não poderia incidir a restrição imposta pelo art.2 $2^{\circ}$, da Lei $n^{0} 2.654 / 55$.

No mérito, concluiu que caberia às duas Casas do Congresso verificar a existência de impedimento para o Presidente da República exercer o cargo. Este poder estaria implícito na competência conferida à Câmara para declarar procedente ou improcedente a acusação contra o Presidente da República e na norma que atribui competência ao Congresso Nacional para autorizá-lo a se ausentar do país. Tendo o Congresso verificado, por maioria absoluta de seus membros, a existência do impedimento, não caberia ao Tribunal rever seu ato.

Ribeiro da Costa, em seu voto, fez questão de frisar que o STF não estaria julgando uma causa política, mas uma causa estritamente jurídica, já que estaria exercendo sua função de interpretação e aplicação da lei, tendo o dever de limitar o Poder Legislativo toda vez que este viesse a exceder sua esfera de atuação constitucionalmente estabelecida. Não abordou a questão do cabimento do mandado de segurança na vigência do estado de sítio. No mérito, entendeu por conceder a segurança, citando a doutrina para mostrar que nenhum dos tratadistas de Direito Constitucional afirmou competir à Câmara dos Deputados decretar o impedimento do Presidente da República. Alegou que, apesar de nunca ter se aproximado das “aras políticas”, pretendia “conduzir a opinião pública a um esclarecimento” para o “amadurecimento da ideia política”:

\footnotetext{
37 Art. $2^{\circ}$ Continuam em vigor as garantias asseguradas pela Constituição Federal, com exceção das previstas nos $\S \S 5^{\circ}, 6^{\circ}, 11,15,20,21,22,23$ e 24 do art. 141, e no art. 142, que ficam suspensas durante o estado de sítio, sendo que as dos $\S \S 20,21$ e 22 do art. 141 subsistem em relação aos indicados de crimes comuns.

Parágrafo único. A suspensão do habeas-corpus restringe-se aos atos praticados por autoridades federais, e a do mandado de segurança aos emanados do Presidente da República, dos Ministros de Estado, do Congresso Nacional e do Executor do estado de sítio.
} 
Estou, pois, bem, no caso: - de um lado, o detentor inautorizado do Poder Executivo; de outro, o Condestável. A ambos rendo justas e merecidas homenagens. Reconheço, contudo, ter sido irrefletido, ato de desrespeito à Constituição vigente, ato de desobediência ao primeiro magistrado da Nação, o que, sem consulta amadurecida praticou o Sr. Ministro da Guerra, declarando ao legítimo titular da Presidência da República, em nome do Exército Nacional, que S.Excia. não poderia reassumir o exercício do cargo.

Ora, esse ato, em face da Constituição, não pode ter guarita, não poderá ser mantido, não poderá subsistir, pois é um atentado, o maior dos atentados que se pode cometer na República, e a lei ordinária o considera crime (lei n. 1.802, arts. $3^{\circ}$ e $6^{\circ}$ ) (COSTA, 1964, p.378).

O ministro Sampaio Costa também afastou as preliminares, mas adotou outro fundamento no que concerne ao cabimento do mandado de segurança. Sustentou que a lei do estado de sítio era de ordem pública, ou seja, de aplicação imediata inclusive aos casos pendentes. Contudo, a Constituição teria aberto a exceção prevista no art.215: “A inobservância de qualquer das prescrições dos arts. 206 a 214 tornará ilegal a coação e permitirá aos pacientes recorrerem ao Poder Judiciário”. Os referidos arts. 206 a 204 estabeleciam quando o estado de sítio poderia ser declarado, as medidas que poderiam ser nele decretadas, a competência para decretação e prorrogação, dentre outras regulamentações. Diante destas disposições, a conclusão do ministro era de que a Constituição autorizaria o conhecimento e a concessão de mandado de segurança e de habeas corpus toda vez que as citadas regras fossem desrespeitadas. No caso ali discutido, o pedido não se baseava em nenhum dos dispositivos constantes dos arts. 206 a 204, sendo, assim, necessário conhecê-lo (para que se verificasse se tratava de transgressões a estes artigos), mas sobrestar seu julgamento até que se expirasse o estado de sítio. Seguindo esta mesma posição, votaram os ministros Afrânio Antônio da Costa, Lafayette de Andrada, Edgard Costa e Orosimbo Nonato.

O ministro Nelson Hungria ousou discordar para apontar o absurdo da posição inaugurada por Sampaio da Costa. Ou o tribunal conheceria do mandado de segurança, reconhecendo a inconstitucionalidade do estado de sítio, para, então, conceder ou negar a ordem, ou não conheceria. A terceira via criada não encontraria base nem jurídica nem lógica. Em seu voto, superou, inicialmente, a preliminar de inadmissibilidade do mandado de segurança contra atos legislativos para declarar que a situação ali discutida se baseava no reconhecimento de uma 
situação de fato, “irremovível dentro dos quadros constitucionais ou legais, qual a criada pelo imperativo dos canhões e metralhadoras insurrecionais que barravam e continuam barrando o caminho do Senhor Café Filho até o Catete.”

O impedimento declarado pelo Congresso era o mais evidente e insuperável possível porque se baseava em obstáculo material do impetrante em reassumir o cargo. Segundo ele, "afastado o manto diáfano da fantasia sobre a nudez rude da verdade”, todos constatariam que uma decisão do Supremo neste caso seria inexequível. E prosseguiu:

Aí está o nó górdio que o Poder Judiciário não pode cortar, pois não dispõe da espada de Alexandre. O ilustre impetrante, ao que me parece, bateu em porta errada. Um insigne professor de Direito Constitucional, doublé de exaltado político partidário, afirmou, em entrevista não contestada, que o julgamento deste mandado de segurança ensejaria ocasião para se verificar se os Ministros desta Corte "eram leões de verdade ou leões de pé de trono".

Jamais nos inculcamos leões. Jamais vestimos, nem podíamos vestir, a pele do rei dos animais. A nossa espada é um mero símbolo. É uma simples pintura, decorativa no teto ou na parede das salas de Justiça. Não pode ser oposta a uma rebelião armada. Conceder mandado de segurança contra esta seria o mesmo que pretender afugentar leões autênticos sacudindo-lhes o pano preto de nossas togas. (COSTA, 1964, p.392)

Terminou, então, não conhecendo do mandado de segurança por entender que a "farmacologia jurídica” não possuiria remédio contra forças insurrecionais.

O ministro Mario de Guimarães, por sua vez, também seguiu o caminho de reconhecer o impacto da realidade fática sobre eventual deliberação jurídica, afirmando que, mesmo que se tratasse de um governo de fato e não de direito, da magistratura, a atitude esperada seria de absoluto respeito. A ascensão ao poder máximo seria assunto de natureza estritamente política: “Não é o direito do Sr. Nereu Ramos ou do Sr. Café Filho, simplesmente, que está em jogo. É a orientação a ser dada aos destinos da Nação. Essa compete aos órgãos políticos, e não a nós. Não conheço, pois, do pedido” (COSTA, 1964, p.405).

Curiosamente, o ministro continuou seu voto para afirmar que, caso tivesse que se manifestar sobre o mérito, concederia a segurança, manifestando algumas críticas ao instituto do impeachment. Ao final, porém, reiterou que não conhecia do mandado de segurança. 
Este caso é especialmente interessante porque, nele, a construção do arcabouço jurídico do voto vencedor foi exposta, tornando explícita sua função retórica. Além disso, ficou clara a importância da disposição interna de cada ministro para intervir na arena política. Dada a conjuntura, todos tinham consciência de que uma decisão determinando o retorno de Café Filho à Presidência dificilmente seria cumprida. Era, então, necessário formalizar uma opção que se traduziria em uma metadecisão ou decisão de segunda ordem (FUX, FRAZÃO, 2015): antes de julgar a questão constitucional, era preciso decidir como decidi-la, escolhendo entre uma atuação judicial mais incisiva ou mais omissa. Diante disso, algumas alternativas eram possíveis. A concessão da segurança representaria uma atitude, de certa forma, corajosa da corte, que, mesmo sem crer na efetividade da medida, estaria se posicionando ao lado das forças que, naquele momento, amargavam uma derrota política, mas apenas um ministro seguiu por este caminho. Não desejando correr os riscos de ver seu julgamento ignorado, o tribunal poderia ter, simplesmente, não conhecido do pedido, acolhendo alguma das preliminares. Contudo, a maioria dos ministros preferiu aderir ao voto do ministro Sampaio Costa, cuja lógica era altamente discutível. Em primeiro lugar, o mandado de segurança havia sido impetrado antes da decretação do estado de sítio, logo, era impossível que nele contivesse a alegação de inconstitucionalidade do decreto. Em segundo lugar, na linguagem jurídica, conhecer de uma ação judicial ou de um recurso significa analisar as questões preliminares e reconhecer que é possível adentrar o mérito do caso. O uso deste termo pelo ministro Sampaio Costa, porém, dá a entender que conhecer o mandado de segurança representaria ler os argumentos que a petição apresenta. Afinal, segundo seu voto, ele precisaria conhecer para saber se a peça tratava da inobservância das regras contidas nos arts.206 a 210 da Constituição. Por fim, a solução escolhida não encontrava nenhum respaldo na jurisprudência relativa ao cabimento de mandando de segurança durante o estado de sítio.

A opção de suspender o julgamento sugere que a maioria dos ministros preferiu um mecanismo que sinalizasse que o tribunal não se posicionou, uma vez que a alternativa de não apreciar o mérito, acatando uma preliminar - ainda que pudesse parecer mais consentânea com os elementos da técnica jurídica - não foi escolhida como a saída adotada para o imbróglio das forças em disputa. 
Preocuparam-se, portanto, mais com o recado passado aos outros atores políticos do que com a apresentação de uma argumentação jurídica convincente. Uma decisão com fundamentação cuidadosa, lastreada na jurisprudência da corte (ao menos, quanto às questões preliminares), poderia aliviar o ônus argumentativo que recai sobre os ombros do tribunal sempre que tem que decidir um caso de tamanho clamor público. Porém, não foi essa a postura assumida pelo tribunal diante do momento político que beirava um conflito armado. O único voto pela concessão da segurança, de Ribeiro da Costa, também dialogou com o público, procurando amenizar a sua tomada de posição, com elogios ao General Lott, e contemporizar o vigor do embate político, clamando pelo cumprimento da decisão na hipótese de seu entendimento sair vencedor.

A definição de qual caminho trilhar diante de uma situação como esta - ou a metadecisão a ser tomada - é expressão de estratégia político-institucional da corte, que precisava definir que papel estrelaria naquele contexto conturbado. A divergência entre os ministros talvez sinalizasse a existência de diferentes posições sobre o fundamento de legitimidade da atuação do tribunal ou sobre o grau de intervenção política a ser assumido pela corte entre os próprios ministros. Os votos vencidos seguiram linhas próprias e lançaram mão de diversos argumentos extrajurídicos.

Além do mandado de segurança impetrado, Café Filho também impetrou habeas corpus, alegando que tropas militares estavam em frente à sua casa, impedindo a sua locomoção e a de seus familiares.

Apesar de, no momento do julgamento, o estado de sítio ainda estar em vigor e, consequentemente, estar mantida a supressão de garantias que ele representava, os ministros, desta vez, pouco se debruçaram sobre a questão do cabimento do habeas corpus. O primeiro a proferir seu voto foi o ministro Afrânio Costa, que julgou prejudicado o pedido porque, em informações prestadas, o Presidente da República em exercício afirmava que o paciente e os que o acompanhavam em sua residência poderiam se locomover livremente.

Ribeiro da Costa, contudo, sustentou a tese de que, se o mandado de segurança teve sua decisão adiada, o habeas corpus também não poderia ser julgado naquele momento. Mas seu argumento não refletia uma preocupação com a coerência em relação aos fundamentos da decisão anterior. O que ele alegava era 
que a discussão naquele $\mathrm{HC}$ tratava de aspectos menores derivados da questão de fundo do mandado de segurança. Se Café Filho era impedido de reassumir a Presidência da República por forças que, em sua concepção, ameaçavam o regime democrático, a existência de tropas na porta da sua casa era uma mera consequência deste quadro. Por fim, afirmou que, se o tribunal não se posicionasse no sentido do adiamento, pediria vista dos autos e se comprometeria a dar seu voto depois de julgado o mandado de segurança.

O relator, Afrânio Costa, se manifestou contra o adiamento, alegando que as matérias decididas no mandado de segurança e no habeas corpus eram totalmente dissociadas. Ao perceber que o ministro Hahnemann Guimarães havia chamado a atenção para o fato de que o adiamento e o pedido de vista de Ribeiro da Costa deveriam ser tratados como questões distintas, este último ministro afirmou: "Sugeri o adiamento por uma deferência para com os meus eminentes colegas, para não parecer que o meu pedido de vista seria uma espécie de tampão" (COSTA, 1964, p.425).

Diante desta situação, a maioria dos votos subsequentes foi no sentido de concordar com o adiamento, à exceção de Nelson Hungria, que marcou sua posição:

Agora, Sr, Presidente, se o eminente Ministro Ribeiro da Costa se declara irredutível no sentido de que se deve adiar este julgamento, para que o Supremo Tribunal tenha oportunidade de uma decisão simultânea, do habeas-corpus e do mandado de segurança, S. Excia. tem o recurso a que já se referiu antecipadamente, qual o de pedir vista dos autos. Que S.Excia. peça vista; mas, não concordo com o adiamento.(COSTA, 1964, p.427)

Este caso permite observar que o uso do pedido de vista, como expressão de grande poder individual dos ministros, não é novidade dos dias atuais, sendo instrumentalizado, inclusive, como barganha na deliberação interna da corte.

No dia 21 de dezembro de 1955, o julgamento do habeas corpus foi retomado e o pedido foi julgado prejudicado contra os votos do ministro Ribeiro da Costa, que concedia a ordem, dos ministros Nélson Hungria e Mário Guimarães, que não conheciam do pedido, e dos ministros Lafayette de Andrada e Orosimbo Nonato que entendiam que o julgamento deveria ser suspenso para aguardar a decisão do mandado de segurança. 
Quanto a este, houve uma tentativa frustrada de retomada do julgamento em janeiro de 1956, decidindo o tribunal por manter o adiamento, considerando que o estado de sítio havia sido prorrogado. Em abril de 1956, o impetrante voltou a peticionar requerendo a apreciação do seu caso, mas somente em 07.11.1956 a petição foi analisada. Nesta oportunidade, os ministros reconheceram a perda do objeto, já que, em 31.01.1956, Juscelino Kubitschek havia assumido a Presidência da República, data em que se extinguiu o mandato anterior.

\subsubsection{2.}

\section{Sessão plenária sobre a lei $n^{\circ} 2.970 / 56$}

No dia 29 de novembro de 1956, antes que se iniciasse o julgamento dos processos incluídos em pauta para aquela data, o ministro Ari Franco chamou a atenção para a sanção da Lei $n^{\circ} 2.970$, publicada no Diário Oficial de 27.11.1956, que estabelecia:

Art. $1^{\circ} \mathrm{O}$ art. 875, caput, do dec-lei $\mathrm{n}^{\circ} 1.608$, de 18 de setembro de 1939 Código de Processo Cível - passa a ter a seguinte redação:

“Art. 875. Na sessão de julgamento. Feita a exposição dos fatos e proferido o voto pelo relator, o presidente, se o recuso não for embargos declaratórios, dará, sucessivamente, ao recorrente e ao recorrido, a palavra pelo prazo improrrogável de 15 minutos, a cada um, para a sustentação das respectivas conclusões, prosseguindo-se de acordo com o regimento interno do tribunal, depois de dada novamente a palavra ao relator para que, expressivamente, confirme ou reconsidere o seu voto".

Segundo o ministro, esta lei seria "duplamente subversiva no fundo, porque estabelece que os advogados tenham a palavra depois do voto do relator, o que é inédito nos anais judiciários do Brasil; subversiva na forma, porque na sua publicação o nome do ministro da Justiça precede o nome do presidente da República.” Diante disso, propôs que a sessão de julgamento fosse suspensa, evitando que algum advogado viesse a pedir a palavra após o voto do relator com base no disposto na lei, para que, no dia seguinte, o plenário se reunisse e decidisse sobre sua aplicação. Esta proposta foi aceita pelos demais ministros e, posteriormente, foi instaurada sessão para que tomassem "parte na questão regimental da lei $\mathrm{n}^{0}$ 2.970, de 24 de novembro de 1956, publicada no Diário oficial de 28-XI-56.” 
Inicialmente, o ministro Ari Franco expôs as razões pelas quais suscitou questão de ordem, indicando que a lei teria avançado em matéria de competência regimental do tribunal, cabendo, portanto, manifestação do Pleno "não só do ponto de vista do regimento como da sua constitucionalidade ou da conveniência de sua pratibilidade; em suma, qualquer que seja o aspecto que o Tribunal queria apreciar.”

O ministro Orozimbo Nonato, presidente da corte na oportunidade, introduziu sua posição afirmando que o Supremo tem o dever de submissão apenas às leis constitucionais e que as leis inconstitucionais não podem ser aceitas "nem para efeito regimental”:

Na hipótese, dados os efeitos que a lei decretada vai ter no regimento, o Supremo Tribunal Federal, com a serenidade de sempre, dirá se ela pode ser aceita em todos os seus reflexos. E como se trata de matéria regimental, peço aos egrégios colegas licença para dar a palavra ao eminente presidente da Comissão de Regimento, Exmo. Sr. Ministro Edgar Costa”.

O ministro Edgard Costa sustentou que as "questões relativas à apresentação, discussão e votação dos feitos submetidos a julgamento, não são normas processuais propriamente, mas disposições que visam a uma melhor ordem e regularidade dos trabalhos, matéria, assim, de natureza regimental.” Logo, considerando que a Constituição estabeleceu que compete aos tribunais a elaboração de seus regimentos internos, concluiu por negar execução à lei 2.970/56.

O ministro Rocha Lagoa chegou a apontar a questão da apreciação da constitucionalidade da lei em abstrato, mas optou por seguir os demais ministros e reconhecer sua inconstitucionalidade:

O Sr. Ministro Rocha Lagoa - Senhor presidente, permita-me Vossa Excelência que, respeitosamente manifeste meu dissentimento quanto à possibilidade de ser declarada inconstitucional uma lei "in abstracto".

Tenho para mim, Senhor Presidente, que só num caso concreto, apreciando a matéria é que este Tribunal poderia pronunciar-se a respeito. Se uma das Turmas ou nesse Tribunal Pleno, algum advogado pedisse a palavra, depois de um juiz ter feito ser relatório, e proferido voto, recusando-se o Tribunal a concedê-la, certo é que no advogado requereria mandado de segurança meio judicial hábil, e ai o Tribunal apreciaria em espécie.

Mas, senhor Presidente, este é um ponto de vista individual meu. Todos os Eminentes Ministros que já se pronunciaram seguram a esteira brilhante de V. 
Excia., entendendo possível a apreciação da matéria, deste, logo, de modo que passarei a dar o meu voto sobre o mérito.

Entendendo que é manifestantemente inconstitucional o diploma legal em apreço e não faço as restrições que já foram feitas.

O ministro Ribeiro da Costa foi veemente ao expressar as razões pelas quais entendeu pela inconstitucionalidade:

O Senhor Presidente, se a Lei número 2.970 tivesse o alto objetivo de construir para o aparelhamento da Justiça um elemento eficaz em seus trabalhos, eu estaria, hoje, nesta Casa, nesta Casa, dando meus aplausos a essa iniciativa.

Ela, porém, foi, Sr. Presidente, sumamente infeliz, porque, ao invés de concorrer, como disse, para construir algo de melhor, ao contrário, vai justamente, desagregar a ordem dos Tribunais Judiciários do Brasil. Vai contribuir para que os julgamentos dos Tribunais percam a elevada serenidade indispensável ao raciocínio e à conclusão dos juízes, porque admitira, fatalmente, não o debate entre as partes mas, sim, Sr. Presidente essa coisa estranha e inominável - o debate entre as partes e o julgador, como se fosse possível exigir do julgador que ele saia da arena restrita do seu pensamento e ao seu julgamento para se travar em discussão com os interesses das partes, para abrir uma polêmica, que, em alguns casos, pode, evidentemente, chegar a um remate alto, nobre e elevado; mas, que, na maioria deles leva sempre, àqueles que se travam em polêmica, pelo menos ao azedome, à malquerença, quando não chega, Sr. Presidente a vias de fato.

Já os ministros Luís Gallotti e Hannemann Guimarães sustentaram, seus votos, que a matéria tratada na Lei $n^{\circ} 2.970$ não era regimental, mas sim processual, não havendo a alegada infringência ao art.97, II, da Constituição.

Adepto da inconstitucionalidade parcial de lei, o ministro Nelson Hungria se preocupou em demonstrar como a norma deixaria os magistrados à mercê de impertinências dos advogados:

Imagina-se, Sr.Presidente, doravante, o juiz relator; após o seu pronunciamento ficar exposto, facie ad faciom, às críticas ditadas pelo unilateralismo do advogado e ser relatado a polêmicas repassadas de azedume...

Foi, naturalmente, um desses advogados teimosos, obstinados, que não se arredam jamais de seus agudíssimos ângulos de visão supondo-se monopolizadores, detentores exclusivo de verdade, que soprou nos ouvidos de Licurgo a formula da lei 2.970. Os juizes relatores estariam sujeitos a todos os atropelos da oratória de tais advogados. Se, há advogados, serenos e corteses, outros há que andam sempre com quatro pedras na mão, não se abstendo de linguagem contundente ou desespeitosamente irônica para com os juízes, esquecidos de que estes são os agentes do Poder Público que mais necessitam do acatamento e crédito de confiança dos que pleiteiam por seus interesses.

Se essa lei fosse constitucional teríamos de admitir que a Constituição deixou os juízes ao desamparo das impertinências de causídicos apaixonados, ficando obrigados a réplicas como se fossem membros do Ministério Público, e não 
tivessem estudado e decido a causa com imparcialidade e meditadamente, através de vigílias e horas a fio.

Depois de votarem todos os ministros, ficou decidido, por maioria, que não se alterasse o regimento por ter sido considerada inconstitucional, in totum, a lei $n^{\circ} 2970^{38}$

Em virtude desta decisão, a questão foi encaminhada ao Senado, que aprovou a resolução 23/1959:

Artigo único - É suspensa, nos termos do art. 64 da Constituição Federal, a execução da Lei $\mathrm{n}^{\circ}$ 2.970, de 24 de novembro de 1956 que modifica o art. 875 (caput) do Código de Processo Civil, em virtude de haver sido, em acordão de novembro do referido ano, do Supremo Tribunal Federal, julgada infrigente do art. 97, n ${ }^{\mathrm{I}}$, da mesma Constituição.

A leitura das manifestações dos ministros neste caso permite observar o esforço para criar uma estratégia legítima para afastar a aplicação de uma lei considerada uma afronta ao status dos magistrados. Afinal, se o advogado pudesse falar após o voto, estaria desfeita a hierarquia das razões do juiz, que poderia ser confrontado com argumentos contrários à sua tese de forma imediata. Nota-se que os ministros, em um primeiro momento, pareciam não saber exatamente como encaminhar a questão, pois teriam que conhecer da inconstitucionalidade sem provocação. Em razão disso, a sessão do Pleno foi convocada sob o pretexto de tratar do regimento interno, mas, ao final, os ministros acabaram por declarar a inconstitucionalidade da lei. Diante disso, a decisão passou a ser tratada como uma hipótese de controle de constitucionalidade em concreto (ainda que não emanasse de uma ação judicial específica), tendo sido encaminhada ao Senado para que peditasse a resolução de suspensão.

A saída encontrada pelo Supremo neste episódio se aproxima da ideia de zona de autarquia de José Rodrigo Rodriguez (2013). A forma jurídica funcionou

${ }^{38}$ Esta questão voltou a ser discutida na ADI $n^{\circ} 1105-\mathrm{DF}$, na qual se impugnava o teor do art. $7^{\circ}$, IX, da Lei n ${ }^{\circ} 8.906 / 94$, que continha previsão semelhante ao art.875 mencionado. Neste julgamento, ficou decidido, por maioria, que a sustentação oral após o voto do relator ofenderia o devido processo legal, além de causar tumulto processual, uma vez que o contraditório se estabeleceria apenas entre as partes. Na ocasião, o ministro Carlos Britto chegou a afirmar que "interpenetrar os momentos do contraditório e do julgamento me parece desnaturar a estrutura lógica do julgamento” $\quad$ (Disponível em $<$ http://redir.stf.jus.br/paginadorpub/paginador.jsp?docTP=AC\&docID=611992>, p.29. Acesso em: 23 mai. 2017) 
como um invólucro vazio para justificar arbitrariedades: a sessão de julgamento foi adiada apenas para que nenhum advogado pudesse lançar mão da prerrogativa prevista na nova lei e a sessão do Plenário foi convocada, sob o argumento da necessidade de resolução de questão regimental, para que houvesse a declaração, ao arrepio da inércia judicial, da inconstitucionalidade da lei.

\subsection{4.}

\section{Ditadura Civil-Militar de 1964}

No final da década de 50, o Brasil vivia um processo de desenvolvimento dependente $^{39}$ baseado no "tripé econômico" - capital multinacional, capital nacional e capital do Estado - que impunha um complexo relacionamento entre desenvolvimento capitalista local e a expansão do sistema capitalista mundial, marcado por uma coincidência de interesses entre classes dominantes locais e internacionais. Como ensina Maria Helena Moreira Alves (2005, p.24), este quadro “implica o desenvolvimento de ‘classes clientelísticas’ cujos interesses associam-se, por meio da propriedade conjunta e de mecanismos formais de cooperação, ao capital estrangeiro, e que portanto apoiam ativamente a penetração internacional na economia nacional”.

Este desenvolvimento dependente e os específicos interesses internacionais formaram o pano de fundo necessário à conspiração civil-militar que derrubou o governo de João Goulart em 31 de março de 1964. De um lado, Goulart havia promovido uma série de restrições ao capital internacional através de políticas como a de controle das remessas de lucros, de pagamentos de royalties e de transferência de tecnologia. Além disso, adotou política nacionalista de concessão de subsídios diretos ao capital privado nacional, sobretudo a setores não vinculados ao capital estrangeiro. Por outro, no final dos anos 50 e início de 60, havia crescido significativamente a mobilização de setores de trabalhadores rurais e urbanos, anteriormente marginalizados da população:

\footnotetext{
${ }^{39}$ Ao contrário dos países centrais, capazes de gerar seu próprio crescimento, as economias dependentes funcionam na periferia do sistema mundial e não possuem mecanismos autônomos para criação de novas tecnologias, expandir seu setor de bens de capitais e controlar seu sistema financeiro e bancário (ALVES, 2005).
} 
O período Goulart foi fértil para a organização da classe trabalhadora; um governo que buscava apoio dos trabalhadores criava um clima político que permitia o desenvolvimento de formas de organização mais profundas e efetivas. A descentralização do sistema político e econômico deu aos Estados real autonomia decisória, o que ficou particularmente patente em Pernambuco, durante o governo de Miguel Arraes, e no Rio Grande do Sul, com a gestão de Leonel Brizola. Embora continuasse a expandir-se o poder do capital multinacional e dos setores nacionais a ele associados, grupos cada vez melhor organizados exigiam participação e uma reforma da altamente estrutura social brasileira. A rápida organização da classe trabalhadora e do campesinato assustou às classes mais altas, que nunca antes haviam sido forçadas a mínimas concessões em questões como salários, condições de trabalho ou mesmo organização sindical. O exemplo de Cuba aumentou o medo de uma revolução que derrubasse o sistema e ocasionasse sérias perdas para o capital nacional e multinacional (ALVES, 2005, p.25).

Na leitura da Adriano Pilatti, a gota d’água para o desencadeamento do golpe foi o comício realizado em frente à estação da Estrada de Ferro Central do Brasil em 13 de março de 1964. Naquela oportunidade, João Goulart anunciaria o envio de mensagem ao Congresso Nacional com sugestão de reforma da Constituição de 1946 para permitir o pagamento em títulos da dívida pública das indenizações por desapropriações de imóveis para a reforma agrária. Comunicaria, também, a assinatura de decretos que desapropriariam terras improdutivas situadas ao longo das rodovias e ferrovias federais, bem como ações de empresas de refinamento de petróleo em favor da Petrobrás ${ }^{40}$.

Em 09.04.1964, foi editado o $\mathrm{AI} \mathrm{n}^{0} 1$, que institucionalizou o golpe de Estado, estabelecendo eleições indiretas para a Presidência da República, a suspensão das garantias de vitaliciedade e estabilidade, a possibilidade de dispensa, demissão ou aposentadoria compulsória de servidores dos três níveis e a possibilidade de cassação de direitos políticos e mandatos legislativos. O General Castelo Branco foi eleito pelo Congresso Nacional e deveria convocar eleições para sua sucessão, mas acabou tendo seu mandato prorrogado até março de 1967.

Apesar das expectativas de imediato afastamento dos ministros do STF ligados a João Goulart, nos primeiros anos de ditadura, o tribunal gozou de

\footnotetext{
${ }^{40}$ Evandro Lins e Silva (1997) faz a mesma avaliação: “É preciso levar em conta o seguinte: Jango queria fazer certas reformas contra as quais as elites brasileiras reagiam e resistiam. Estava-se caminhando para a realização das reformas não se desse de maneira pacífica, como queria o governo, pela reforma da Constituição. Isso, a meu ver, fez com que o clima fosse aquecendo. O comício da Central do Brasil, em frente ao Ministério da Guerra, no dia 13 de março de 1964, foi a gota d'água."
} 
relativa autonomia. Hermes Lima e Evandro Lins e Silva chegaram a ser alvos de ataques da imprensa, que estranhava que a revolução tivesse permitido a manutenção de "dois comunistas na Corte Suprema"41. No entanto, os ministros foram mantidos, sendo que as primeiras intervenções no tribunal ocorreram em 1965 com a promulgação da $\mathrm{EC} \mathrm{n}^{\circ} 16$ e com a edição do $\mathrm{AI} n^{\circ} 2$.

A principal inovação da referida emenda constitucional foi a introdução do controle concentrado de constitucionalidade por meio da alteração da alínea K do art.101, I, da Constituição de 1946. Esta alteração, que, à primeira vista, poderia parecer uma ampliação de poderes, foi interpretada como um artifício do regime autoritário para controle do Judiciário:

Aliás, a circunstância de a legitimidade ativa para a RI ser exclusiva do Procurador-Geral da República, à época detentor de cargo de livre-nomeação e exoneração pelo Presidente e responsável pela chefia da advocacia da União, denotava que o propósito da instituição do controle abstrato no Brasil não era o de fortalecer o papel do Judiciário de protetor dos direitos fundamentais, senão o de transformar o STF em instrumento do regime, notadamente para imunizar os efeitos de decisões judiciais indesejadas (BRANDÃO, 2012, p.114).

Já o AI-2 aumentou o número de ministros de 11 para 16, passando o tribunal a ser dividido em três turmas. Segundo Evandro Lins e Silva (1997), dizia-se "que o aumento do número seria para neutralizar a influência daqueles considerados adversários da Revolução. Mas se enganaram, porque os cinco nomeados chegaram lá e passaram a votar absolutamente de acordo conosco nos processos políticos.” Já para Aliomar Baleeiro:

A meu ver, Castello Branco, diante daquele antagonismo da Revolução aos cinco ministros do STF, cuja filosofia política ela reputava hostil às suas diretrizes, encarou duas soluções drásticas: a) aposentá-los, como fez Vargas em 1931, em relação aos juízes execrados pelos revolucionários de 1922, 1923, 1924 e 1930; ou b) elevar de quase $50 \%$ o número dos ministros, como tentou fazê-lo F. D. Roosevelt aos “Justices” incompatíveis como New Deal. Castello conhecia perfeitamente o projeto de packing the Court, de Roosevelt, pois a ele se referiu em conversa comigo cerca duma semana antes do AI $n^{\circ} 2$. Preferiu a solução menos brutal e que viria a corrigir a congestão das pautas do STF. Não me parece que tivesse cometido, com isso, um erro tático. Em política raramente a escolha é entre o bom e o ruim, mas a menos má entre duas soluções más, sem melhor alternativa. (BALEEIRO apud KOATZ, 2015)

\footnotetext{
${ }^{41}$ Artigo intitulado "Expurgo no âmbito do Judiciário" foi publicado no Estado de São Paulo de 14.04.1964 e sugeria a ampliação da "depuração geral por que está passando o país” para o âmbito do Judiciário, citando expressamente Evandro Lins e Silva e Hermes de Lima. (SILVA, 1997, p.410)
} 
A introdução do controle concentrado de constitucionalidade e o aumento do número de ministros, portanto, são medidas que não refletiam, de fato, o fortalecimento e a autonomia do tribunal. O controle concentrado, em um cenário de Supremo domesticado, permitiria uma aparência de ampliação de competências judiciais, mas não necessariamente representaria uma expansão de seu papel político.

A repressão, entretanto, foi recrudescendo com a chegada ao poder do General Costa e Silva. A edição do AI-5 foi um marco na institucionalização da ditadura, passando a permitir que o Presidente decretasse o recesso do Congresso e conferindo poderes legislativos ao Executivo durante este recesso. Foram suspensas garantias da magistratura, ficou autorizado o confisco de bens e suspendeu-se a garantia constitucional do habeas corpus. Com base neste mesmo ato, em 16.01.1969, foram aposentados os ministros Victor Nunes Leal, Evandro Lins e Silva e Hermes Lima. Lafayette de Andrada e Antônio Gonçalves de Oliveira deixaram a corte em solidariedade, mas especula-se que este último também seria aposentado se não o requeresse (SILVA, 1997). Depois disso, o Supremo se tornou refém das arbitrariedades do regime, perdendo qualquer característica de independência.

Nos primeiros anos de convivência do STF com a ditadura, contudo, é possível observar exemplos de julgados corajosos, em que ministros expunham suas posições ideológicas através de votos e, mesmo aqueles de viés mais conservador, não se colocavam como partidários do governo militar.

\subsubsection{1.} $\mathrm{HC} \mathrm{n}^{\circ} \mathbf{4 0 . 9 1 0}$

Sérgio Cidade Resende, professor da Universidade Católica de Pernambuco, teve sua prisão preventiva decretada sob acusação de crime contra a ordem política e social por ter distribuído a seus alunos, em sala de aula, material considerado contrário à situação vigente. O habeas corpus impetrado perante o STF sustentava que os fatos imputados ao paciente não constituíam crime e que 
ele exercera sua liberdade de pensamento e de cátedra garantidas nos arts.141, §5 e 168, nº VII, da Constituição de 1946.

O pedido foi julgado procedente por unanimidade, sendo interessante registrar que o ministro Pedro Chaves, simpatizante da ditadura civil-militar ${ }^{42}$, fez questão de pontuar que concordava com os demais ministros "exclusivamente no terreno legal”. O ministro expôs seu entendimento no sentido de que as previsões da Constituição de 1946 eram eminentemente liberais e, portanto, de difícil compatibilidade com o AI n ${ }^{\circ} 1$. Na sua concepção, seriam necessários mecanismos “de defesa às instituições nacionais” e os democratas que fizeram a Constituição de 1946 que asseguraram ampla liberdade "se esqueceram de assegurar medidas de defesa dessas mesmas liberdades para que não se voltassem contra nossos próprios interesses, nacionais ou coletivos.” Em outras palavras, ele defendia que era necessário que o Estado se protegesse da ameaça comunista, antecipando medidas de cunho autoritário para evitar que fosse implantada uma ditadura tal qual a dos países socialistas.

Diante deste aparte, o ministro Vítor Nunes Leal se manifestou:

Senhor Presidente, enquanto ouvia o voto do eminente relator, era meu pensamento limitar-me a dar-lhe a minha adesão, porque Sua Excelência demonstrou, de maneira cabal, que o fato atribuído ao paciente não é crime, sequer pela Lei de Segurança, em que se procurou enquadrá-lo. Entretanto, o debate, que se seguiu, desbordou um pouco do aspecto legal, penetrando num problema constitucional da magna importância - a liberdade de pensamento, particularmente a liberdade de cátedra (COSTA, 1967, p.13).

Depois desta introdução, o ministro prosseguiu defendendo a importância da liberdade de cátedra e citou um caso ocorrido nos EUA, quando o Chief Justice Warren acentuou que esta liberdade era um princípio fundamental na organização política norte-americana.

\footnotetext{
${ }^{42}$ Em seu voto no HC nº41.296, o ministro Pedro Chaves afirmou: "Recebi a Revolução de 31 de março como uma manifestação da providência divina em benefício da nossa Pátria. Não me mantive antes em atitude contemplativa. Tive coragem de alertar a Nação, em discurso de 11 de agosto de 1962, para o desfiladeiro tenebroso a que estávamos sendo conduzidos, resta-me ainda hoje, ânimo para conceder a ordem jurídica, único caminho pelo qual o eminente Sr. Presidente da República poderá conduzir a Nação Brasileira, como é de seu desejo, aos seus gloriosos destinos.” (COSTA, 1967, p.56)
} 
O ministro Evandro Lins e Silva também baseou seu voto na experiência dos Estados Unidos, citando o juiz Douglas da Suprema Corte norte-americana. Posteriormente, comentando este caso, o ministro afirmou:

Fiz muita questão de calcar meu voto na opinião de Douglas, até por estratégia política, para mostrar que aquelas acusações que me faziam, de esquerdismo quando votava, não procediam, porque eu estava baseado na opinião de um liberal, de um juiz da Corte Suprema americana. Não há dúvida de que houve ali, talvez, até uma certa malícia política. Tanto que quando o ministro Pedro Chaves dizia que estava inteiramente contrário às minhas ideias, estava contrário às idéias do Douglas, e não às minhas, porque eu não expus como minhas. De qualquer maneira, os votos dos ministros foram politizados. Então não era político o voto sustentando a liberdade de cátedra, num instante em que o governo não queria a liberdade, estava demitindo professores? A concessão do habeas corpus representou um ponto de vista jurídico-político do Tribunal, porque havia alguns ministros que até podiam ser simpáticos ao movimento militar, mas não podiam tolerar que fosse cortada a liberdade de cátedra (LINS, 1997, p.387).

Note-se, assim, que, apesar das discordâncias de fundo, o resultado do julgamento refletiu um esforço por uma solução, de fato, jurídico-política. Entretanto, na condução dos votos, as estratégias políticas se revelaram, seja através da postura dos ministros de não se limitar a acompanhar o voto do relator, expondo razões que iam além da configuração ou não de crime na hipótese julgada, seja através da utilização de argumentos de direito comparado com o objetivo dar ao posicionamento um caráter desvinculado da política nacional. A questão que o ministro Vítor Nunes chamou de "problema constitucional de magna importância”, em realidade, não estava diretamente em jogo no debate, afinal, ninguém havia discordado que a Constituição de 1946 protegia a liberdade de cátedra. O motivo da divergência tinha origem nas concepções políticas pessoais dos ministros, que desejaram expressá-las e defender suas visões mais amplas sobre o papel do Estado nas restrições às liberdades. Já o argumento baseado no direito norte-americano foi escolhido não por ser, necessariamente, o melhor em termos jurídicos, mas porque conferia verniz apartidário ao posicionamento adotado, uma vez que os Estados Unidos nunca poderiam ser exemplo de solução comunista para um embate entre direitos.

\subsubsection{2.}


Este habeas corpus foi impetrado em favor de Francisco Julião Arruda de Paula, deputado federal por Pernambuco, que teve seu mandato cassado e sua prisão decretada em função do $\mathrm{AI} \mathrm{n}^{0} 1$. Os atos imputados ao paciente foram classificados como de natureza militar, previstos na lei 1.802/53, e estavam relacionados com a acusação de que Francisco Julião trabalhava junto a Ligas Camponesas para implementar agitação popular e instituir o comunismo no Brasil.

Os argumentos da defesa eram no sentido de que a imputação não configurava crime e que, mesmo que configurasse, não seria de competência militar. Arguiam, ainda, o excesso de prazo da prisão preventiva.

O relator ministro Luiz Gallotti entendeu que deveria ser mantido o acórdão do Superior Tribunal Militar que já havia negado habeas corpus ao paciente. Fez apenas duas ressalvas. A primeira era para consignar que, na sua visão, não era possível admitir qualquer excesso de prazo, mesmo que justificado. A segunda era no sentido de que existiria jurisprudência do STF afirmando que o prazo de 60 dias do art.43, §2 , da Lei $\mathrm{n}^{0} 1.802 / 53$ não se aplica à prisão preventiva. Esta posição teria sido consagrada no $\mathrm{HC}^{0}$ 32.618, de relatoria do ministro Nelson Hungria, restando vencido o ministro Hahnemann Guimarães. O relator ressalva, que, em casos recentes, contudo, o STF, por maioria, vinha aplicando o entendimento do ministro Hahnemann e não aquele de Nelson Hungria, que havia sido transcrito como exemplo da interpretação dada pelo tribunal ao art.43, da Lei $n^{0} 1.802 / 53$. Conclui afirmando que, naquele caso concreto, o excesso de prazo era justificável e por isso não concedia a ordem.

Os ministros Evandro Lins e Silva e Hermes de Lima divergiram, sustentando que concordavam com a interpretação dada pelo ministro Hahnemann Guimarães ao art.43, da Lei $\mathrm{n}^{\circ} 1.802 / 53$ e ressaltando que o excesso de prazo da prisão não deveria admitido.

O ministro Vítor Nunes Leal, logo no início de seu voto, pediu vênia para listar uma série de julgados recentes em que a corte tinha entendido que era necessário observar o prazo do mencionado artigo ou do art.222 do Código da Justiça Militar. Diante disso, o seguinte diálogo foi travado entre ele e o relator: 
Ministro Luiz Galotti: - Aliás, acentuei no meu voto que decisões recentes tiveram o prazo de 60 dias do art.43 como aplicável à prisão preventiva. Mas, nos casos em que estive presente e a matéria foi suscitada, fui voto vencido.

Ministro Vítor Nunes: - Respeito muito a opinião de V.Exa., mas a opinião do Tribunal...

Ministro Luiz Galotti: - Não estou dizendo isto, para que V.Exa. respeite minha opinião, mas, apenas, para assinalar minha coerência, como coerente será V.Exa.

Ministro Vítor Nunes: - Não estou discutindo esse aspecto. Desejo apenas citar os casos mais recentes: HC 40.207 (9-10-63); HC 40.383 (18-3.64); HC 41.018, HC 40.030, HC 41.044, HC 41.014, HC 41.033, HC 41.040, (15-10-64); HC 41.019, HC 41.037, HC 41.022 (15-10-64); RHC 41.141 (29-10-64); HC 41.928, HC 41.208, HC 41.249 (10-3-65); RHC 41.249, RHC 41.951, HC 41.892 (24-3-65); HC 42.145 (1-4-65); HC 42.127 (7-4-65); RHC 42.143, HC 42.100, HC 42.111 (7-4-65); HC 42.048 (12-4-65); HC 42.094 (13-4-65); HC 41.895 (22-4-65); HC 42.222, HC 41.971 (28-4-65); HC 42.021 (29-4-65); HC 42.181 (3-5-65), RHC 12.199 (5-5-65); HC 42.221, RHC 42.176 (12-5-65); HC 41.262 (19-5-65); HC $42.314(24-5-65)$

Há vários outros, evidentemente, mas, por serem tão reiterados esses julgamentos, não os anotei todos (COSTA, 1967, p.182).

Todos os demais ministros seguiram a divergência, sendo que o ministro Gonçalves de Oliveira ressaltou não estar “solidário com os camponeses das Ligas Camponesas”, mas que “estar um homem preso um ano e meio nessas condições atenta contra a própria República”. Em seguida, o ministro Vítor Nunes Leal sentiu-se na obrigação de esclarecer que esta mesma ressalva estava contida de forma implícita em seu voto e que não havia, em suas palavras, “qualquer adesão a tais processo de agitação” (COSTA, 1967, p.184).

A preocupação dos ministros de não parecerem apoiadores dos camponeses era natural, considerando a marca autoritária do governo instituído pelo golpe civil-militar. O caso envolvia uma figura política relevante e, certamente, a decisão teria grande repercussão. A utilização da jurisprudência, neste sentido, poderia aliviar o ônus argumentativo dos ministros que pretendiam deferir a ordem, já que afastaria acusações de casuísmo ideológico no posicionamento assumido ${ }^{43}$. O ministro Galotti, contudo, lançou mão de julgados

\footnotetext{
${ }^{43}$ Evandro Lins e Silva opinando sobre as divergências do tribunal naquela época, relatou: "O fato de haver um ministro divergindo de mim individualmente não tem importância alguma. Ele está dando uma definição, inclusive, da sua posição política, da sua posição ideológica. Não significa nada de mais grave. O problema está em o Tribunal decidir em um sentido e depois num outro. (...) O Ministro Vítor Nunes, por exemplo, era um homem que tinha um método, uma organização extraordinária. Ele anotava todos os votos proferidos no Supremo, tinha uns caderninhos que eu chamava de 'cadernos implacáveis', e de vez em quando nos denunciava, com muita delicadeza, como sendo incoerentes com algum voto anterior.” (1997, p.396)
} 
anteriores, mesmo sabendo que aquela não era a interpretação que prevalecia no tribunal, apenas para "assinalar sua coerência” como voto vencido, em uma postura que vai de encontro à própria racionalidade do uso da jurisprudência e que denunciava um processo de deliberação marcado pelo individualismo dos ministros.

\section{3. \\ Conclusões}

Os julgados citados ao longo deste capítulo revelam algumas das diversas estratégias político-institucionais que o STF assumiu na sua história. Como já mencionado anteriormente, o equilíbrio de forças entre os Poderes parece ter tido ingerência direta na forma como a corte operava.

Apesar das diferenças de contextos políticos, é possível destacar, de uma maneira geral a partir das decisões citadas, duas características da atuação do STF que parecem estar presentes nos diversos períodos descritos ainda que se manifestando em graus diversos: a ausência de zelo do tribunal com a construção de sua jurisprudência e o aparente descuido, enquanto instituição, com o ônus da ação argumentativa da corte. Este último aspecto poderia ser identificado com a apresentação de uma fundamentação falha, que pecava, em alguns momentos, pela falta de clareza e coerência, atrapalhando a compreensão e o controle democrático do que ficou decidido. Poderia ser associado, ainda, à dificuldade de identificação de uma linha argumentativa do acórdão, que não se limitasse à sobreposição dos votos proferidos pela maioria vencedora.

Investir nestes dois pontos parece não ter sido encarado como uma estratégia interessante para o fortalecimento da corte. Ao contrário, no passado, quando demandada sobre eles, considerou as críticas como interferência indevida das forças políticas na sua atuação. O caminho para a consolidação de seu poder parecia ser visto mais como uma busca pelo monopólio e pela autonomia do discurso jurídico em face do político do que pela abertura para a discussão sobre suas práticas institucionais. 
O personagem político que vai se construindo ao longo do tempo, portanto, é aquele que parece encontrar seu alicerce fundamental em uma cultura jurídica pouco afeita ao diálogo e pouco preocupada em fundar sua legitimidade em uma racionalidade discursiva. 


\section{3 \\ O STF e a política a partir da Constituição Federal de 1988}

\section{1. \\ O novo constitucionalismo latino-americano $e$ as razões de entusiasmo com a intervenção das cortes constitucionais}

Depois do longo período de vigência da ditadura civil-militar no Brasil, a promulgação da Constituição de 1988 representou um marco na institucionalidade brasileira. Nas palavras de José Rodrigo Rodriguez (2013), ela representou “uma possibilidade real de mudança no padrão de institucionalização que vigorou em nosso país por pelo menos um século.” Seu processo de elaboração contou com intensa participação da sociedade civil e seu texto, amplo em garantias sociais, teve papel fundamental na construção do modelo de legalidade adotado no período de redemocratização. Na avaliação de Antonio Carlos Wolkmer:

A Constituição Federal de 5 de outubro de 1988, não obstante manter ainda certo perfil republicano liberal, analítico e monocultural, foi a mais avançada, relativamente a qualquer outro momento da história brasileira. Tal traço deve-se por haver ampliado a gama de direitos fundamentais (e suas garantias) e por ter inaugurado amplas perspectivas pluralistas em seus diferentes campos de ação, como o religioso, filosófico, político e cultural. Assim, a chamada "Constituição Cidadã" consagra o Pluralismo, agregando a ele o adjetivo "político", num sentido muito mais abrangente. Trata-se do art. $1^{\circ}$, inciso V, da Constituição Federal, que proclama como um de seus eixos fundamentais, o princípio do pluralismo político pautado na convivência e interdependência de diversos grupos sociais (minorias especiais, movimentos sociais, organizações não governamentais, etc.), não obstante suas diferenças e suas diversidades quanto crenças, valores e práticas (2015, p.257/258).

As expectativas geradas pelo novo texto constitucional permitiram que, no âmbito do pensamento crítico do direito, fluíssem indagações sobre os limites das transformações sociais a partir das transformações jurídicas ${ }^{44}$. São possíveis

\footnotetext{
${ }^{44}$ José Rodrigo Rodriguez (2013) observa que as críticas ao Direito no Brasil mudaram de tom: “A condenação completa - e sem direito a recurso - do direito brasileiro tem passado em cobranças por sua efetivação, na própria linguagem dos movimentos sociais. Nosso sistema político tem sido constantemente confrontado com as promessas contidas na Constituição de 1988: a distância entre
} 
reformas profundas sem as necessárias mudanças nas bases materiais que transcendessem o texto constitucional? Por outro lado, quais os limites da capacidade transformadora de reformas parciais?

Estas e outras questões permeiam o debate do constitucionalismo latinoamericano contemporâneo ${ }^{45}$. As recentes Constituições promulgadas, como a da Bolívia e do Equador ${ }^{46}$, proporcionaram um momento de entusiasmo com o potencial transformador do direito, sendo vistas como instrumentos de superação de paradigmas e avanços no sentido da descolonização e da implementação do pluralismo jurídico. Muitos autores passaram a falar em um novo constitucionalismo latino-americano, que não seria reprodução do neoconstitucionalismo europeu, focado na discussão sobre princípios e regras (BALDI, 2015). Este novo constitucionalismo seria marcado por constituições que, além de preverem uma grande extensão de direitos, buscaram promover uma nova institucionalidade, incorporando setores marginalizados da população e criando mecanismos de democracia participativa. ${ }^{47}$

lei e a realidade informa os discursos e a ação política no direito no Brasil, o que significa, de certa forma, a aceitação implícita da mediação do direito na discussão da esfera pública.” (p.44)

${ }^{45}$ Esta abordagem do ponto de vista regional se justifica porque as especificidades históricas, econômicas e sociais de países como Brasil, Argentina, Colômbia, Costa Rica e Equador forçam a encarar temas como o constitucionalismo e a revisão judicial com perspectiva diversa daquela norte-americana ou europeia .Como observado por Garavito e Franco (2015), nestes países, proliferam os contrastes e a má distribuição da riqueza, sendo que a própria atuação das instituições é assimétrica. Esta realidade cria um campo fértil para que, diante de tribunais independentes, demandas judiciais sejam instrumentalizadas para a garantia de direitos fundamentais.

${ }^{46}$ Para resumir a importância das constituições da Bolívia e do Equador na seara do que se convencionou chamar de novo constitucionalismo latino-americano: "A etapa mais significativa e de grande repercussão acerca do que vem a ser o denominado novo constitucionalismo latinoamericano é aquela representada pelas transformadoras e vanguardistas Constituições do Equador (2008) e da Bolívia (2009). Para alguns publicistas, tais textos políticos expressariam um constitucionalismo plurinacional comunitário, identificado com um outro paradigma não universal e único de Estado de Direito, coexistente com experiências de sociedades interculturais (indígenas, comunais, urbanas e camponesas) e com práticas de pluralismo igualitário jurisdicional (convivência com instâncias legais diversas em igual hierarquia: jurisdição ordinária estatal e jurisdição indígena/camponesa).”(WOLKMER, 2015, p.260).

47 Carlos Rivera Lugo (2016) descreve os elementos que caracterizam este novo constitucionalismo: “ ¿Puede hablarse en estos tiempos de posibilidades subversivas o usos emancipatorios del Derecho? Por un lado, se encuentra el llamado nuevo constitucionalismo latinoamericano que toma distancia del marco constitucional liberal para alzarse con nuevos sentidos normativos enraizados en la potenciación de una nueva esfera de lo común más allá de las esferas privada y pública a las que se han reducido las posibilidades de la gobernanza democrática y socialmente incluyente. Se trata de un nuevo constitucionalismo societal que se va potenciando hoy en Venezuela, Ecuador y Bolivia. Me refiero a un proceso abierto y plural de prescripción normativa que se potencia y fluye tanto al interior como más allá del Estado, como expresión de una nueva situación de fuerzas en la que una pléyade de sectores sociales, hasta hace poco excluidos de toda participación real en los procesos constitutivos y decisionales del orden 
Este contexto proporcionou também novas análises sobre a jurisdição constitucional na região, com destaque para as experiências de algumas cortes mais progressistas. Ao preverem direitos e garantias fundamentais ao progresso social, estas novas constituições incorporaram um olhar para o futuro, mas afeito ao discurso político do que ao jurídico ao seu texto (VILLEGAS, 2015). Esta ambivalência entre o jurídico e o político potencializou as tensões institucionais entre as maiorias políticas e os órgãos judiciais, particularmente, entre os órgãos de representação democrática encarregados de implementar políticas públicas e os juízes responsáveis por proteger os direitos sociais consagrados no texto constitucional $^{48}$. Diante disso, o Judiciário ganhou protagonismo na cena política e a discussão sobre seu déficit democrático, novo fôlego no meio acadêmico.

De fato, é compreensível que tenham sido grandes as esperanças semeadas quando cortes constitucionais de países como a Colômbia, onde ocorrem graves violações de direitos humanos, passaram a exportar jurisprudência com enfoques inovadores no sentido da preservação destes direitos ${ }^{49}$. Garavitto e Franco (2015) defendem que o tribunal constitucional colombiano lançou mão de um tipo específico de ativismo $^{50}$, ainda incipiente em outros países latino-americanos e em

prevaleciente, son sus protagonistas principales (Rivera Lugo, en NINA, 2012, p. 147). Estos nuevos sujetos, ausentes o marginados bajo el constitucionalismo liberal, han determinado apropiarse de su poder normativo como sujetos soberanos para conformar el contenido del nuevo constitucionalismo a sus propias creencias y prácticas societales, independientemente de su reconocimiento formal por el Estado.”

${ }^{48}$ Matthew Taylor (2008) aponta como elemento inerente à cultura jurídica dos membros do Judiciário brasileiro um ethos de proteção aos vulneráveis que contribui para uma nova forma de ativismo e para novos tipos de conflitos entre os Poderes de Estado.

${ }^{49}$ Mauricio García Villegas afirma que, na Colômbia, com um sistema político muito inclinado à direita e com uma participação popular débil, era muito difícil que a Constituição de 1991 pudesse ter suas previsões efetivadas através do órgão legislativo ou do poder executivo: "Esta constitución no fue el produto de una revolución social y por lo tanto no hubo um movimento político detrás de su creación (Lemaitre, 2009). Fue más la indignación nacional frente a la violencia narcotraficante y frente a la clase política tradicional que lo desperto el apoyo ciudadano a la Asamblea Nacional Constituyente. En esas circunstancias, era factible que uma constitución muy progresista, como lo fu ela que resultó de esa asamblea en 1991, sin um partido fuerte detrás para respaldarla, tuviera que ser desarrollada por la Corte Constitucional, cuyos jueces no eran particularmente progresistas pero eran buenos juristas, desinteresados políticamente, los cuales se vieron, digámoslo así, atados al texto constitucional muy progresista de 91. A todo esto contribuyó el hecho de que em Colombia hubiese uma tradición de autonomia judicial muy flerte (desde el plebiscito de 1957) y un certo apego a las rutinas institucionales y a las formas del derecho; em todo caso más flerte que em sus vecinos (Uprimny, 2001; Rodríguez-Garavito, 2011; Saffón y García Villegas, 2011).” (2015, p.238)

${ }^{50}$ É importante mencionar que, no caso colombiano, existe um fator de extrema relevância que permite o protagonismo da corte constitucional: a facilidade de acesso à jurisdição constitucional. Carlos Alexandre de Azevedo Campos (2014) descreve os dois principais instrumentos para submissão de demandas ao tribunal: 
outras regiões, visível, principalmente, nas decisões proferidas nos casos estruturais em que existem violações generalizadas a direitos econômicos, sociais e culturais (DESC):

Juntamente com a incorporação dos DESC às constituições nacionais, essas intervenções judiciais são inovações cruciais cujo objetivo é solucionar as injustiças socioeconômicas fundamentais que se refletem na privação de condições materiais básicas de uma vida digna, da qual padecem, entre outros, milhões de habitantes de bairros de invasão, os membros de minorias éticas e raciais, as crianças desnutridas, as vítimas de discriminação de gênero e de violência sexual, os refugiados e as PDI ${ }^{51}$, os desempregados crônicos, as legiões de trabalhadores da economia informal, os imigrantes sem direitos e as pessoas sem acesso à educação, saúde e saneamento básico. ${ }^{52}$

A tese destes autores é de que os tribunais são componentes fundamentais no processo de mediação para redução da dominação e da exclusão radical geradas pela desigualdade social. Para eles, assim como a justiça transicional é essencial nos períodos seguintes ao término de governos autoritários, aos tribunais caberia o papel de intervir nos debates distributivos, de definir limites dos sistemas jurídicos e econômicos, bem como de atuar para modificar o destino de milhões de cidadãos, cujas condições materiais de vida estão em jogo. Os casos estruturais, que afetam um grande número de pessoas e envolvem diversos órgãos públicos, seriam um campo fértil para este tipo de atuação, já que permitem sentenças abrangentes e fomentariam o diálogo ente Estado e sociedade civil a respeito dos problemas distributivos.

\footnotetext{
“A accione pública pode ser manejada por qualquer cidadão para questionar a inconstitucionalidade das leis, sem necessidade de advogado ou de qualquer formalismo. A accione de tutela, por sua vez, criada pela Constituição de 1991 para os cidadãos defenderem os direitos constitucionais, é um capítulo à parte. Segundo importante doutrina, a ação de tutela tem levado a 'constituição mais próxima aos cidadãos dotando-os de um elástico instrumento para a proteção de seus direitos’, de forma que não é exagero afirmar sua destacada relevância para 'a ‘constitucionalização’ do direito e para importantes aspectos da vida dos Colombianos'. Com todo este amplo acesso à sua jurisdição, a Corte tem sido sempre convocada para manter vivas as promessas de direitos e desenvolvimento social da Constituição de 1991, respondendo às demandas de forma sem precedentes na história colombiana e com um ativismo destacado até mesmo para os padrões norte-americanos.”

${ }^{51}$ Sigla que define pessoas em deslocamento forçado interno.

52 Tradução da autora para o trecho: "Junto con la incorporación de los DESC a las constituciones nacionales, esas intervenciones judiciales son innovaciones cruciales cuyo objetivo es solucionar las injusticias socioeconómicas fundamentales que se reflejan en la privación de las condiciones materiales básicas de una vida digna, padecida, entre otros, por los millones de habitantes de barrios de invasión, los miembros de minorías étnicas y raciales, los niños malnutridos, las víctimas de la discriminación de género y de la violencia sexual, los refugiados y las PDI, los desempleados crónicos, las legiones de trabajadores de la economia informal, los emigrantes sin derechos y las personas sin acceso a educación, salud o alcantarillado de calidad.”
} 
Além da Colômbia, a Corte Suprema da Índia, quanto aos problemas massivos de fome e desnutrição, e a Corte Constitucional Sul-africana, quanto aos problemas de moradia e saúde, teriam tido experiências positivas a partir de casos estruturais. Na América-Latina, os autores citam o papel dos tribunais na garantia do direito à saúde, observando que, na Argentina, foram julgados casos estruturais e experimentados mecanismos públicos para fiscalizar a implementação das sentenças ativistas, como no caso "Verbitsky”, sobre superpopulação carcerária.

Este tipo de jurisprudência repercutiu no Brasil, onde foi ajuizada a ADPF 347 para que fosse declarado o estado de coisas inconstitucional no sistema carcerário brasileiro. O mérito da ação ainda não foi julgado pelo STF, mas o plenário referendou em parte a liminar concedida pelo ministro Marco Aurélio Mello para determinar a implementação das audiências de custódia e a liberação, sem qualquer tipo de limitação, do saldo acumulado do Fundo Penitenciário Nacional (FUNPEN) para utilização na finalidade para o qual foi criado, proibindo a realização de novos contingenciamentos. Tanto a realização das audiências de custódia quanto o controle sobre a liberação do FUNPEN vêm sendo implementadas através de projetos conduzidos pelo Conselho Nacional de Justiça, sendo que, no caso do fundo, foi celebrado convênio com o Ministério da Justiça.

É possível concluir a partir dos argumentos expostos por Garavitto e Franco que a legitimidade conferida às cortes constitucionais para o exercício deste tipo de ativismo quanto aos DESC guarda relação, em primeiro lugar, com uma intervenção judicial dialógica, que não prescinde da interação com os demais poderes e com a sociedade civil. Esta atuação, segundo eles, acabaria por aprofundar a deliberação democrática porque estimularia mecanismos de seguimento participativos, como audiências públicas e convites a órgãos públicos e à sociedade civil para participação de discussões promovidas pelo tribunal. Em segundo lugar, a legitimidade estaria ancorada na situação de bloqueio institucional, que levaria a graves deficiências ou a uma ausência completa de políticas públicas destinadas a resolver problemas sociais urgentes. Diante deste quadro, caberia aos tribunais eliminar os obstáculos para o funcionamento apropriado do Estado, o que terminaria por fortalecer a democracia ao invés de 
erodi-la. A intervenção judicial, em casos assim, complementaria atuação do governo e do Congresso ao invés de substitui-la.

Por mais que, em muitos momentos, a visão dos autores pareça idealizada quanto ao potencial a ser exercido pelos tribunais em matéria de efetivação de direitos sociais, é preciso reconhecer, em sua análise, um ponto relevante da discussão a partir da ótica latino-americana: aqui, os contrastes econômicos caminham em paralelo com os contrastes institucionais. Nossas instituições são híbridas, sendo que, em seu interior, convivem elementos de debilidade e de força, com atuações oscilantes a depender da situação concreta. Ademais, esta assimetria pode ocorrer, em um determinado contexto histórico, entre instituições diversas. Pode acontecer de um governo capturado por interesses privados conviver com juízes independentes que protegem os direitos dos cidadãos, por exemplo (GARAVITO \& FRANCO, 2015). Diante disso, conclusões que, simplesmente, inabilitem a atuação de um determinado órgão podem se revelar precipitadas ou radicais em um contexto de posturas ambíguas no cenário político.

Outro ponto relevante de observação sob a ótica latino-americana é aquele relativo a uma preocupação com a descentralização de poderes. É que a história regional em comum parece ensinar que é preciso evitar a tendência ao hiperpresidencialismo, personalizado, muitas vezes, em de um líder carismático, para garantir a participação democrática. Roberto Gargarella (2014) parte da premissa que presidentes com poderes muito fortes tendem a não aceitar recortes em seu campo de ação. Daí que a convivência entre cláusulas constitucionais que prevejam mecanismos participativos e aquelas que concentram nas mãos do Executivo amplas competências tenderiam a enfraquecer os instrumentos de intervenção cidadã. Neste cenário, o fortalecimento dos órgãos de cúpula do Judiciário não seria visto, necessariamente, com maus olhos, já que, mesmo sem significar participação popular direta, representaria um sinal de divisão de poder. Nas palavras de Eduardo Mendonça (2015), nesta hipótese, a jurisdição constitucional funcionaria como válvula de segurança contra propensões autoritárias ${ }^{53}$.

\footnotetext{
${ }^{53}$ Eduardo Mendonça, contudo, ressalva que é preciso relativizar o discurso romântico de que a jurisdição poderia se tornar uma barreira efetiva contra maiorias tirânicas: "Uma sociedade que dependa de uma atuação imediata dos magistrados para não cair em um ciclo de autoritarismo dificilmente escapará desse percalço” (2015, p.148).
} 
Entretanto, mesmo reconhecendo estes pontos positivos, é preciso ponderar que ainda haveria muito a conquistar no sentido de um constitucionalismo democrático ideal. Mauricio García Villegas, estudando as formas de operacionalizar a garantia dos direitos previstos constitucionalmente e participação política, traz uma classificação interessante que pode ser analisada através do quadro que se reproduz abaixo:

\begin{tabular}{|c|c|c|c|}
\hline \multirow{4}{*}{ : } & \multicolumn{3}{|c|}{ Participação das maiorias } \\
\hline & & Menos & Mais \\
\hline & Menos & $\begin{array}{c}\text { I } \\
\text { Constitucionalismo } \\
\text { Preservador }\end{array}$ & $\begin{array}{c}\text { II } \\
\text { Constitucionalismo } \\
\text { Aspiracional-majoritário }\end{array}$ \\
\hline & Mais & $\begin{array}{c}\text { III } \\
\text { Constitucionalismo } \\
\text { Aspiracional-judiciário }\end{array}$ & $\begin{array}{c}\text { IV } \\
\text { Constitucionalismo } \\
\text { Democrático }\end{array}$ \\
\hline
\end{tabular}

Tabela 1

De acordo com estas categorias, o constitucionalismo preservador seria aquele mais focado na limitação do poder e na manutenção do status quo, enquanto o constitucionalismo aspiracional seria aquele que relaciona Constituição e progresso social, conectando-se com o futuro. O autor adverte que esta distinção teria um caráter mais analítico que descritivo, já que, na prática, pode haver, em uma mesma Constituição, normas de ambos os tipos e que quase todos os textos constitucionais se movem na fronteira difusa entre direito e política, entre a garantia do presente e a promessa do futuro ${ }^{54}$.

\footnotetext{
${ }^{54}$ Outra observação do autor é que as constituições aspiracionais atuais se nutrem da tradição rousseauniana ou francesa de constitucionalismo, mas aquelas que dependem, para sua efetividade, da intervenção de juízes, se alimentam, sobretudo, da tradição constitucional anglo-saxã de ativismo judicial e de controle contramajoritário.
} 
Neste diapasão, os extremos seriam os campos I e IV, sendo que, este último, seria o modelo ideal em que seria possível reunir o máximo de participação democrática possível compatível com o máximo de proteção de direitos possível. O caso I, pelo menos para a América Latina, seria o mais deficiente, já que não atenderia aos reclamos urgentes de sociedades marcadas por profunda desigualdade social.

As hipóteses II e III seriam variações do modelo aspiracional, sendo que o III poderia ser exemplificado com a experiência colombiana e o II com a experiência venezuelana, em que a efetivação da Constituição de 1999 se apoiou em maiorias políticas através da figura do ex-presidente Hugo Chávez. Diferentemente da Colômbia, na Venezuela foi o poder político, radicado em bases bolivarianas, que ditou a dinâmica institucional.

Ambos os casos intermediários apresentariam deficiências importantes em relação ao modelo ideal de constitucionalismo democrático ${ }^{55}$. O modelo colombiano falhou no aprofundamento da democracia através do fortalecimento dos partidos e dos mecanismos de participação cidadã, resultando em um quadro em que atores políticos foram substituídos pelo protagonismo judiciário. O modelo venezuelano pecou pelo excesso de concentração de poder, alcançado através de medidas como a ampliação do mandato presidencial, da criação de uma Assembleia Nacional unicameral em substituição a uma bicameral e, sobretudo, na obtenção de poderes excepcionais para o Executivo legislar por decreto.

A experiência brasileira estaria, talvez, entre os dois modelos intermediários, já que o projeto social contido na Constituição de 1988 encontrou respaldo em políticas públicas implementadas durante os doze anos de governo do Partido dos Trabalhadores. Por outro lado, a classe política vem enfrentando forte crise de credibilidade e o STF ganhou grande importância no cenário institucional. Este tribunal, contudo, não produziu jurisprudência progressista da mesma

${ }^{55}$ Outra forma de abordagem do tema da compatibilidade entre garantia de direitos e participação política é aquela que considera que só haveria democracia em um contexto de igualdade material razoável. Esta concepção pode ser relacionada às ideias desenvolvidas nas obras de Habermas e Rawls e parte da premissa de que os direitos fundamentais são condições de existência da democracia deliberativa. Ainda a partir desta perspectiva, as constituições deveriam estabelecer apenas a estrutura básica do estado democrático de direito, permitindo que diversos projetos sociais pudessem ser encapados. Neste quadro, o papel do Judiciário seria proteger os direitos fundamentais contra arroubos da maioria, hipótese em que, mesmo agindo para limitar o princípio majoritário, estaria exercendo a função de guardião do funcionamento democrático da sociedade (NETO, 2006). 
relevância dos casos estruturais famosos da Colômbia, da Índia e da África do $\mathrm{Sul}^{56}$. Além disso, apesar de ter implementado mecanismos como as audiências públicas $^{57}$, as soluções dialógicas não tiveram efetividade expressiva, tanto no que concerne à relação com os demais poderes quanto em relação à participação da sociedade civil.

Os limites da capacidade transformadora da opção que depende dos tribunais para efetivação de direitos fundamentais são muitos. Roberto Gargarella (2014) aponta como principal falha nos textos constitucionais latino-americanos recentes um certo descompasso entre a parte dedicada à organização do poder e à parte dedicada aos direitos. Enquanto esta última revela avanços, a primeira ainda se mantém altamente hierarquizada e sem prever mecanismos que permitam a ampliação do acesso àquilo que o autor chama de sala de máquinas da Constituição. Para ele, o grande desafio que a região enfrenta continua sendo a desigualdade social e, para combate-la, poucos inimigos são tão perigosos quanto a falta de democratização da política e da economia. Uma generosa carta de direitos representaria, assim, uma tentativa de atalho, fadada, no entanto, a conduzir ao caminho oposto ao que deveria seguir. A desigualdade no acesso ao poder alimenta a desigualdade no acesso aos direitos, impedindo que se alcance o objetivo de reforma social. Seria necessário interromper este processo de tradução de exigências fundamentais, que antes se apresentavam como disputa político-

\footnotetext{
56 Daniel Brinks (2010) resume da seguinte maneira a atuação recente do STF em termos de proteção de direitos: "Las resoluciones del STF en favor de la expansión de los derechos pueden ser descritas como la protección de la classe media, de las demandas de la corriente dominante, a menudo outorgando poderes al gobierno para empreender acción, en lugar de solicitar acción gubernamental adicional. El STF decidió, por ejemplo, que el gobierno puede imponer controles de precios em las escuelas privadas em nombre del derecho a la educación, y que las instalaciones de salud privadas están sujetas a obligaciones constitucionales provenientes del derecho a la salud (Hoffmann y Bentes, 2008, 122-26). Sin embargo, no ha seguido adelante com la expansión del acceso a la assistência sanitária o a la educación, imponiendo obligaciones adicionales al gobierno nacional $^{56 ”, ~(p .243) ~ D i a n a ~ K a p i s z e w s k i ~(2010) ~ t a m b e ́ m ~ a v a l i a ~ q u e ~ o ~ h i s t o ́ r i c o ~ d o ~ S T F ~ n a s ~ d u a s ~}$ décadas posteriores à redemocratização no Brasil sugere que ele exerceu um papel pouco relevante na proteção de direitos, principalmente, daqueles de natureza socioeconômica.

57 Sobre a implementação das audiências públicas nos julgamentos do STF, Conrado Hübner Mendes (2008) avalia que, muitas vezes, este tribunal adota uma retórica inflamada, mas é tímido em suas práticas, ou seja, "late mais não morde”: "Um vício recente, que provavelmente entra como mais uma técnica do "latir", é a forma como se está utilizando a audiência pública, sem grande teorização sobre o seu papel ou critérios transparentes para organizar seu procedimento. Virou uma espécie de teatro auto-legitimatório, com especialistas de todos os tipos apresentando argumentos, mas com pouca ou nenhuma deliberação. Um ministro do STF, celebrando tal prática, recentemente declarou em seu voto que o STF tem sido também uma "casa do povo, tal qual o parlamento”. O STF não precisa e não pode ser “casa do povo, tal qual o parlamento”. Pode, talvez, ser casa do povo, mas nunca ‘tal qual o parlamento'.”
} 
social, em linguagem de direitos, investindo em uma radicalização e em uma politização da sociedade.

Neste sentido, talvez seja necessário levantar algumas questões sobre o modelo adotado de separação de poderes. Roberto Mangabeira Unger (2011) coloca em discussão a naturalização da associação entre o princípio liberal de fragmentar o poder para controlá-lo e o princípio conservador de estabelecer mecanismos que desacelerem o uso transformador da política. Para este autor, não existiria esta relação entre estes dois princípios, sendo que seria necessário eliminar a severidade de obstáculos que se opõem à ambição transformadora de qualquer projeto político. O pensamento constitucional que predomina no Ocidente seria conduzido por uma estrutura binária equivocada: Madison contra Mussolini. A oposição entre uma política institucional fria, com baixo nível de mobilização, e uma política extrainstitucional ou anti-institucional quente, com alto grau de mobilização, seria falsa e faria parte da mitologia do pensamento conservador.

Outro ponto levantado por Magabeira Unger se aproxima da crítica formulada por Gargarella e diz respeito a, de um lado, constitucionalização de expectativas sociais e, de outro, à ausência de correspondência em um modelo de organização econômica e social subjacente que possa, de fato, assegurar a realização daqueles objetivos:

A tradição das constituições de Weimar representa a expressão, no domínio do pensamento constitucional, da barganha socialdemocrata do século XX. As forças que procuravam reorganizar o poder e a produção abandonaram a tentativa. Em troca desse abandono, permitiu-se a elas construir, no Estado, esfera forte de distribuição ou de redistribuição. Assim, o leitmotiv da política progressista do século XX passou a ser a humanização do inevitável. (...)

Tardios que somos, temos de cumprir simultaneamente a tarefa que resultou na construção social-democrata e a tarefa que ultrapassa os limites desta construção. Nossa adesão à primeira parte do weimarismo transformou-se em uma das muitas maneiras que temos de fugir da tarefa em vez de enfrenta-la e cumpri-la.

A proposta deste autor seria romper de vez com o que ele chama de "weimarismo truncado e tardio", que não teria funcionado para superar os problemas, representando apenas tentativa frustrada e tímida de alargar os limites de um constitucionalismo protodemocrático. 
Nesse ponto, voltamos ao dilema já mencionado entre as reformas amplas e a introdução de reformas mais localizadas e limitadas, que possam conter certa capacidade de intervenção na realidade social. José Rodrigo Rodriguez pondera que:

Como discutido (ver “A talk to cradle bovines”), há algum tempo no Brasil intensas crises políticas e econômicas têm sido resolvidas pelas instituições e não com ruptura. Quinze anos de normalidade institucional não são garantia de que este padrão tenha continuidade no futuro, mas o fato de que, em larga medida, os movimentos sociais tenham assumido a Constituição como elemento constitutivo de sua ação, que o três poderes estejam funcionando sem ignorar a existência do direito, que agentes públicos tenham sido responsabilizados pelos atos ilícitos que cometeram com certa regularidade são fatores positivos que levam a crer no enraizamento do que estamos chamando de "novo padrão de reprodução institucional” (2013, p.57-58).

Diante disso, mesmo que apostemos que reformas localizadas tenham potencial para surtir efeitos abrangentes, sua força transformadora depende do aprofundamento deste “novo padrão de reprodução institucional”. Ainda que sem romper radicalmente com as estruturas de poder estabelecidas, é preciso manter as instituições sob constante questionamento, sempre colocando à prova os argumentos que sustentam a superioridade do modelo adotado. A preocupação com a garantia dos direitos fundamentais, ainda que crucial para a realidade brasileira, não deve impedir uma inquirição mais profundas sobre a atuação do Supremo Tribunal Federal no contexto democrático brasileiro.

Quando se procura, assim, pensar em limites para a atuação do tribunal, deixa-se de lado a busca por uma resposta abstrata sobre que instituição deve prevalecer na cena política, passando-se a analisar, diante da realidade concreta, as vantagens comparativas dos parlamentos e das cortes, desmistificando alguns pontos que parecem só se verificar nas teorias. Para tanto, faz-se necessário expor à crítica as diversas dimensões da performance política do STF, ampliando o espectro da discussão sobre o funcionamento da instituição em um esforço para que sejam desenvolvidos mecanismos de prestação de contas com amplitude comparável à de seus poderes e mais próximos daqueles a que são submetidas as demais esferas políticas. 


\section{2.}

\section{Qual o papel do STF no pós-1988?}

Quando trabalhamos com um modelo que, de certa forma, se alicerça em instituições não majoritárias como o Judiciário, enfrentamos o complexo desafio de construir os limites de atuação deste órgão no jogo político. Afinal, se a centralização de poder nas mãos do Executivo é uma ameaça a ser evitada, o fortalecimento do STF em uma cultura jurídica pouco democratizada e sem parâmetros claros de prestação de contas à sociedade pode representar perigo ainda maior. No que concerne às funções executivas, sabemos exatamente quando os excessos se manifestam e quando há usurpação de competências de outros poderes. Mas e quanto ao Judiciário? Quais são os critérios para saber quando o STF cumpre legitimamente sua tarefa? Qual papel esperamos que ele exerça? O que importa é apenas a função última que sua decisão exerce na sociedade ou os procedimentos adotados para chegar até ela também contam?

Daniel Sarmento e Cláudio Pereira de Souza Neto (2015) defendem que jurisdição constitucional e democracia possuem uma tensão sinérgica e que o problema não residiria no remédio, mas na dosagem. Quando a corte constitucional passa a concentrar a solução de todos os conflitos sociais, políticos e morais mais relevantes da sociedade haveria um exagero antidemocrático. A fórmula, porém, não seria universal, mas dependeria de fatores contingentes como o grau de representatividade dos poderes políticos majoritários, sua performance na proteção de direitos fundamentais e de minorias, a credibilidade e independência do sistema judicial, e a existência, no âmbito do Poder Judiciário, de uma cultura não elitista, aberta aos anseios dos grupos mais vulneráveis da população. O problema deste argumento é que os elementos para avaliação da atuação da corte possuem alto grau de subjetividade e ele não contempla indicadores mais concretos de accountability. Quem avalia o que é uma performance satisfatória em termos de direitos fundamentais? Qual o grau de não elitismo admitido? Como se mede o nível de representatividade dos poderes políticos majoritários e qual o marco que legitima a jurisdição constitucional? Segundo o rol de fatores elencados, as práticas do tribunal não são objeto de observação e nem funcionam como critério para crítica (pelo menos, não aquelas 
que não chegassem a atingir seriamente a credibilidade do sistema judicial). A forma como o tribunal lida com ameaças à sua credibilidade, por exemplo, não seria relevante ${ }^{58}$. Conquistado o apoio da opinião pública, parece que os fins justificariam os meios utilizados no processo decisório. Os parâmetros para julgamento da compatibilidade de sua atuação com critérios de legitimação democrática, portanto, seriam muito menos exigentes do que aqueles aplicados ao Executivo e ao Legislativo.

O risco que se corre ao adotar tal concepção é permitir o fortalecimento de uma instituição que não é pressionada a se democratizar e a quem se torne impossível a imposição de limites. Se, na concepção dos autores, não haveria nada a temer enquanto houvesse uma performance positiva em termos de direitos fundamentais, por outro lado, não existiria nenhum instrumento que impedisse que a corte modificasse sua linha de julgamento quanto a estes direitos e se mantivesse superpoderosa.

Eduardo Mendonça (2015), porém, taxa de simplista e contrafactual concepções que temem por um protagonismo indesejado do STF. Ele advoga a tese de que a jurisdição não possui capacidade efetiva de se impor incondicionalmente às forças políticas, já que não há, na história, nenhum caso real de juristocracia. Ao contrário, regimes autoritários não enfrentam dificuldade em domesticar o Judiciário e moldá-lo à sua imagem e semelhança.

É possível concordar com este autor de que não é necessário que adentremos neste cenário tão extremo. Entretanto, como já mencionado acima, é a

\footnotetext{
${ }^{58}$ Sobre formas de reagir a denúncias que poderiam atingir a imagem da corte, vale citar como exemplo o caso do suposto vazamento da delação premiada de Léo Pinheiro, ex-presidente da empreiteira OAS, que envolvia o nome do ministro Dias Toffoli. A reportagem da revista "Veja" que divulgou o que seria o conteúdo de tal delação provocou reação destemperada no ministro Gilmar Mendes, que levantou a possibilidade de os próprios procuradores do Ministério Público terem induzido o delator a dar "resposta desejada ou almejada contra pessoas que, no entendimento deles, estejam contrariando seus interesses.” Ainda criticando o MPF, afirmou: "Já estamos nos avizinhando do terreno perigoso de delírios totalitários. Me parece que [os procuradores da Lava Jato] estão possuídos de um tipo de teoria absolutista de combate ao crime a qualquer $\quad$ preço". (Disponível em: <http://www1.folha.uol.com.br/colunas/monicabergamo/2016/08/1805944-vazamento-de-citacaoa-toffoli-em-delacao-abre-crise-entre-stf-e-mpf.shtml>. Acesso em: 10 fev. 2017.) A reação do Procurador-Geral da República também é digna de nota, já que ele decidiu por interromper as negociações para o acordo de delação sob o argumento de quebra de confidencialidade. Vale mencionar que esta quebra de confidencialidade ocorreu em outros acordos de delação premiada anteriores que envolviam políticos sem, contudo, desencadear este tipo de resposta veemente. Ver mais em: <http://www1.folha.uol.com.br/opiniao/2016/08/1806266-dois-pesos.shtml>. Acesso em: 10 fev. 2017.
} 
qualidade das instituições que permitirá ou não um bom grau de mudança social, ainda que esta seja limitada pela ausência de reformas de base. A performance de uma corte constitucional pode provocar riscos ao bom funcionamento de uma democracia mesmo sem conseguir impor todas as suas preferências políticas à sociedade. Pensar os limites do exercício do poder pelo STF não significa acreditar que ele, de fato, passará a governar o país, mas representa tentativa de incremento das instituições, de submetê-las a uma crítica permanente e necessária à lógica democrática. Por outro lado, aceitar que a jurisdição constitucional não é uma força desviante do ambiente democrático não implica a simplificação das dificuldades enfrentadas. A conjunção de fatores que supostamente geraria uma legitimação contingente da atuação das cortes não pode impedir de enxergar as diversas nuances que permeiam suas funções. É esta observação mais ampla, que contemplaria aspectos variados de suas práticas, que parece ser a mais difícil diante dos casos concretos.

Um exemplo que ilustra esta incerteza quanto aos critérios de atuação a serem exigidos do STF é aquele relativo ao HC 126.292, em que prevaleceu a tese, por maioria de 7 votos a 4, da possibilidade de execução provisória da pena após o julgamento pela $2^{\text {a }}$ instância, afastando-se a exigência de trânsito em julgado. Esta decisão foi alardeada como uma mudança de entendimento da corte que, desde 2009, condicionava a execução da pena ao trânsito em julgado da condenação, com ressalva para a possibilidade de prisão preventiva ${ }^{59}$. Foi, também, objeto de muitas críticas da comunidade jurídica por flexibilizar a garantia prevista no art.5\%, LVII, da Constituição Federal ${ }^{60}$. Meses depois de proferido o acórdão, o decano Celso de Mello e o presidente da corte Ricardo Lewandowski, ambos vencidos naquele julgamento, proferiram decisões monocráticas contrárias ao entendimento consagrado no referido habeas corpus. No caso de Lewandowski, sua liminar, que tinha sido concedida no plantão, foi revogada de ofício pelo ministro Edson Fachin ao fim do recesso do tribunal, sob

\footnotetext{
59 Esta divulgação foi realizada pelo próprio sítio institucional do Supremo: <http://www.stf.jus.br/portal/cms/verNoticiaDetalhe.asp?idConteudo=310153>. Acesso em: 12 set. 2016.

${ }^{60}$ Como exemplo de análise crítica da decisão: <http://www.ibccrim.org.br/boletim_artigo/5740Presuncao-de-inocencia-A-pre-ocupacao-de-inocencia-e-o-julgamento-do-HC-126292SP-peloSTF>. Acesso em: 12 set. 2016.
} 
o argumento de que era necessário que a corte conferisse estabilidade à sua própria jurisprudência.

Como avaliar esta situação? Tratando-se de caso que envolve o princípio da presunção de inocência, a exigência de estabilidade na jurisprudência torna-se um argumento menor ${ }^{61}$ ? Ou o respeito aos julgamentos anteriores do plenário deve ser colocado em primeiro plano, já que “a jurisprudência não merece tal nome se variar ao sabor das percepções pessoais momentâneas”,62? Ou, ainda, uma terceira via: considerando que coerência e integridade sempre deveriam ser analisadas em conjunto, o argumento da coerência não pode ser invocado em nome de uma decisão que não respeite a integridade do sistema jurídico ${ }^{63}$ ?

Esta ausência de parâmetro se reflete também quando lançamos mão do conceito de ativismo. O problema para defini-lo é fruto, dentre outras questões, de não se saber qual seria a "atuação padrão" do tribunal. Se considerarmos o ativismo como um desvio de conduta $^{64}$, quais são os critérios que definem a conduta correta?

Em razão disso, alguns autores se debruçam sobre a questão da definição de balizas para a autocontenção judicial, buscando delinear um norte para atuação da corte. Daniel Sarmento e Cláudio Pereira de Souza Neto, por exemplo, propõem sete parâmetros: (i) Grau de legitimidade democrática (quanto mais democrática a elaboração do ato normativo, menor deve ser a intervenção da

\footnotetext{
${ }^{61}$ Esta parece ser a tese defendida por Leonardo Isaac Yarochewsky em artigo intitulado "Procurase constitucionalista que faça valer os princípios constitucionais” publicado no site Consultor Jurídico. Disponível em: <http://www.conjur.com.br/2016-ago-17/leonardo-yarochewsky-procuraconstitucionalista>, acesso em: 18 ago. 2016)

${ }^{62}$ Frase dita pelo ministro Edson Fachin em sua sabatina no Senado e reproduzida por Felipe Recondo no artigo "Execução provisória da pena: inversão de papéis no Supremo" publicado no JOTA. Disponível em: < http://jota.uol.com.br/execucao-provisoria-da-pena-inversao-de-papeisno-supremo>, acesso em: 18 ago. 2016.

${ }^{63}$ Argumento desenvolvido no artigo "Teori do STF contraria Teori do STJ ao ignorar lei sem declarar inconstitucional” de Lênio Streck. Disponível em: <http://www.conjur.com.br/2016-fev19/streck-teori-contraria-teori-prender-transito-julgado>. Acesso em: 12 set. 2016.

${ }^{64}$ Carlos Alexandre de Azevedo Campos (2014) defende que o ativismo nada diz, a priori, sobre a legitimidade das decisões judiciais. Segundo ele, como a concepção mais difundida de ativismo é pejorativa, tende-se a fazer esta associação com a ilegitimidade: "Muitos chamam de ilegítimas as decisões ativistas porque elas seriam usurpadoras dos poderes políticos dos órgãos legitimados pelo sufrágio popular, ou fundadas exclusivamente nas preferências políticas ou morais do próprio julgador, dentre outros motivos. Prevalecendo a noção negativa, a ilegitimidade seria uma enfermidade congênita das decisões judiciais ativistas, e o ativismo judicial seria espécie do gênero arbítrio judicial”. Segundo este autor, a avaliação de eventual ilegitimidade só pode ser feita diante do caso concreto, observando os limites institucionais impostos pela Constituição e pelas diferentes variáveis políticas e sociais presentes.
} 
corte); (ii) Condições de funcionamento da democracia (a intervenção deverá ser mais vigorosa quando o caso envolver institutos diretamente relacionados ao funcionamento da democracia); (iii) Proteção de minorias estigmatizadas (a proteção aos direitos deste grupo justificaria uma relativização da presunção de constitucionalidade das leis); (iv) Relevância material do direito fundamental em jogo (normas que restrinjam direitos básicos passariam por um escrutínio mais rigoroso); (v) Comparação de capacidades institucionais (o Judiciário deveria levar em consideração a sua falta de expertise sobre determinados assuntos, adotando postura contida em áreas que demandem profundos conhecimentos técnicos); (vi) Época de edição do ato normativo (as normas anteriores a 1988 não desfrutariam da mesma presunção de constitucionalidade que as leis editadas já sob a égide da nova carta constitucional ${ }^{65}$, especialmente, em razão da retomada democrática que ela representou) (vii) Compensação da "inconsistência temporal" (a jurisdição constitucional funcionaria como guardiã de interesses a longo prazo da sociedade, já que os ministros não dependeriam de sucesso eleitoral para se manterem no cargo, diminuindo o risco de que a lógica da política majoritária sacrificasse em demasia o futuro).

Embora critérios como os acima elencados possam contribuir para uma salutar limitação do poder de revisão judicial se incorporados pelo STF, eles não parecem resolver todo o problema do controle da atuação política do tribunal. Isso porque muito do incômodo gerado pela judicialização da política não diria respeito, unicamente, ao fato de o STF proferir decisões sobre questões que deveriam ficar a cabo da política majoritária ou anular legislação votada no Parlamento, mas ao produto final da intervenção desta corte no ambiente político. Este produto é composto da jurisdição constitucional exercida, mas, também, de todos os procedimentos e recursos à disposição do tribunal para alcançar este resultado. Dentre estes recursos, podemos citar a autonomia de escolher quais as brigas está disposto a comprar, ou seja, no poder de eleger entre uma agenda passiva e ativa, entre uma inércia deliberada e uma atuação proativa. Junto com estes existem outros elementos com os quais se preocupar como, por exemplo, o

65 O princípio da recepção determina que a legislação editada na vigência de uma ordem constitucional anterior se mantenha válida desde que não conflitante com as disposições da nova Constituição. O STF não admite Ações Diretas de Inconstitucionalidade contra leis anteriores à Constituição de 1988, mas a impugnação é possível através de Ação de Descumprimento de Preceito Fundamental. 
grande poder individual dos ministros frente ao colegiado, sua liberdade para se manifestar publicamente sobre casos em julgamento ou na iminência de serem submetidos ao Judiciário, a dificuldade na construção de jurisprudência estável e as consequências intencionais da confusão jurisprudencial. A forma como exerce o seu poder ou como manifesta sua identidade poderia, assim, ser avaliada segundo dois aspectos: um procedimental e um substancial. Apenas este último poderia ser quantificado através de dados que atestassem o número de decisões invalidando atos de outros poderes ou de julgados que exerceram função legislativa sob a faceta de interpretação constitucional. Em outras palavras, os limites propostos e citados anteriormente só teriam o condão de atuar na substância da decisão, no que diz respeito à intensidade da revisão judicial sobre atos legislativos. Mas o diagnóstico geral da prática política do STF não poderia se limitar a estas informações quantitativas. ${ }^{66}$

Uma hipótese a ser levantada é de que um dos principais problemas na avaliação das decisões do STF (se expressam ativismo, se foram proferidas fora das competências estabelecidas constitucionalmente para aquele órgão, se legítimas ou não, dentre outros aspectos) passa por uma dificuldade de identificar e pesar, na crítica, estes níveis diversos da sua atuação. Uma decisão que, em seu conteúdo, protege minorias estigmatizadas pode, por exemplo, ser proferida estabelecendo regras e princípios amplos que dirigirão casos futuros, deixando pouco espaço para legislação a ser produzida sobre o assunto. É o que apontam ARGUELLES e RIBEIRO com relação à ADPF 132, que, em seu acórdão, considerou que a Constituição proíbe o preconceito e demanda o reconhecimento de união estável entre pessoas do mesmo sexo. Sem discordar do mérito e da importância de uma decisão que protege direitos fundamentais, os autores observam que, através dela, o STF formalizou teses que deixam pouco ou nenhum espaço para o Congresso regulamentar o tema:

\footnotetext{
${ }^{66}$ Este tipo de abordagem coincide, em parte, com o que Carlos Alexandre de Azevedo Campos (2014) classificou como a dimensão do ativismo relativa a autoexpansão da jurisdição e dos poderes decisórios, através da qual o tribunal interpreta regras procedimentais de forma a ampliar o alcance de seu poder. Entretanto, engloba também o que Diego Werneck Arguelhes e Leandro Molhano Ribeiro (2016) denominaram de flexibilidade decisória: "Para além dessas mudanças explícitas nas regras que estruturam sua competência, em muitos aspectos a prática institucional do tribunal parece ter se desenvolvido de crescente flexibilidade, por parte dos ministros, na configuração do seu poder e das oportunidades de exercê-lo. Dois exemplos podem ser encontrados nas formas pelas quais o tribunal (i) filtra quais casos serão efetivamente julgados por seus ministros, e quais serão simplesmente rejeitados em decisões monocráticas; e (ii) determina sua agenda o timing de suas decisões.”
} 
A decisão do STF já respondeu de antemão todas as perguntas ao dizer que a Constituição exige que todas as regras de direito de família criadas para casais de sexos diferentes devem ser idênticas às regras aplicáveis a casais formados por pessoas do mesmo sexo. A princípio, portanto, por um movimento interpretativo feito pelo STF, o Congresso foi movido para fora do jogo. (2016, p.32)

Conforme assinalado pelos autores, “a jurisdição do tribunal foi provocada não contra uma lei aprovada no Congresso e que representaria um ataque a direito de minorias”, nem seria o caso de uma omissão, mas sim da existência de uma lei inadequada. Diante disso, ao analisar o art.1.723 do Código Civil, que previa a união estável apenas entre homens e mulheres, o ministro relator Ayres Britto, acompanhado pela maioria dos ministros, não se limitou a afirmar que a interpretação constitucional do artigo deveria abranger pessoas do mesmo sexo, mas já indicou que uma futura legislação deveria prever a paridade de situações jurídicas de forma absoluta.

Se utilizarmos os parâmetros sugeridos por Sarmento e Neto, citados acima, a decisão da ADPF 132 seria irrepreensível, já que não invalida ato normativo de indiscutível legitimidade democrática, mas confere a ele interpretação que seria mais consentânea com a proteção de minoria estigmatizada. Entretanto, se observarmos a forma como o STF exerceu seu poder de jurisdição constitucional, seria possível identificar uma atuação pouco democrática quando este órgão monopoliza e encerra a discussão, estabelecendo uma regra de abrangência ampla, excluindo outros relevantes atores políticos da definição de questões relativas ao tema.

Neste sentido, o desafio seria ponderar estes elementos de natureza diversa, permitindo que a discussão alcance vários níveis. A dificuldade democrática da instituição não se restringe aos momentos em que profere decisões que contrariam as opções formuladas pela esfera majoritária, mas alcança também as formas de exercício do poder. Para esta análise, as teorias sobre legitimação da jurisdição constitucional podem e devem servir de base, mas precisariam ser utilizadas de forma a contemplar as diversas nuances da atuação do STF.

Como bem assinalado por Diego Werneck Arguelles (2017), “o desenho de uma instituição é um indicador das expectativas que temos com relação ao papel que ela deve cumprir; esse papel pode ser múltiplo, mas não tão ampliado a 
ponto de englobar qualquer tarefa possível”. A discussão, portanto, sobre a legitimidade da atuação do STF envolve a compatibilização entre as expectativas que temos em relação a ele e os limites do seu poder ${ }^{67}$. O fato de serem muito relevantes as funções que esperamos que tribunal exerça não pode significar uma total ausência de restrições à sua atuação como instituição e de seus membros individualmente considerados ${ }^{68}$.

Partindo desta premissa, um dos fatores de legitimação com maior apelo, tendo em vista a situação de emergência social dos países da América Latina conforme tratado na seção anterior, é aquele que diz respeito à efetivação dos direitos fundamentais.

Contudo, utilizar a garantia de direitos fundamentais como termômetro para a legitimidade da atuação do STF apresenta, pelo menos, um óbice de difícil transposição: como observa Conrado Hübner Mendes (2008b), a análise empírica da sua efetivação dependeria de juízos valorativos, que oscilarão a depender da ótica individual em uma sociedade marcada pelo desacordo moral. Seria impossível demonstrar a preservação daqueles direitos de forma incontroversa sem a uniformidade de concepção sobre o conteúdo destes mesmos direitos. Logo, o argumento segundo o qual a legitimidade da jurisdição constitucional se

\footnotetext{
${ }^{67}$ Como observa Conrado Hübner Mendes, a cultura política das democracias contemporâneas legou-se uma série de imagens sobre juízes e cortes. Lidar com todo este simbolismo é um fardo pesado que as cortes constitucionais carregam: "Como instituição encarregada de avaliar a constitucionalidade das escolhas políticas ordinárias, a corte constitucional é vista como o bastião da defesa de direitos, uma salvaguarda contra os perigos da opressão majoritária. Isso nem sempre aconteceu em virtude do que as cortes historicamente fizeram, mas, sim, pela expectativa do que devam fazer. Imagens não são apenas fugas retóricas que confudem o grande público sobre aspectos intangíveis da adjudicação. Há, frequentemente, conceitos, expectativas e argumentos por trás delas. Tais conceitos prescrevem funções que delimitam o raio de ação de um tribunal” (2012, p.55).

${ }^{68}$ É preciso cautela para evitar a supervalorização do papel do Judiciário e, como consequência, a adoção de uma concepção excludente que confia no órgão dotado de "superioridade técnica" as decisões mais caras à sociedade: "Por um lado, sobrecarregar o Judiciário com a expectativa de que este Poder possa ser 'o protagonista' do processo de transformação social gera não só decepções inevitáveis, mas também, em certos casos, percepções elitistas de nossa estrutura institucional. Por detrás dessa supervalorização do Judiciário como agente de transformação da sociedade está situada uma descrença no potencial transformador do voto popular, decorrente de uma profunda desilusão com a nossa recente democracia. (...) No fundo, essa percepção, mesmo que eventualmente com sinal trocado, não difere muito, p. ex., da proposta de tornar o banco central independente. No cerne das duas propostas, está a velhíssima utopia platônica; está a crença nos 'reis filósofos', nos 'monarcas ilustrados' e na 'vanguarda revolucionária”” (Neto, 2006).
} 
manifesta na medida em que ela proporciona a garantia de direitos não poderia ser comprovado ${ }^{69}$.

Além disso, mesmo que não fosse a dificuldade acima expressada, justificar toda a atuação do tribunal com base em único fator que envolve a natureza do caso apreciado também é problemático. E quando não estão em jogo direitos fundamentais, como medir a legitimidade da corte?

Fernando Ângelo Leal (2017) observa que o argumento que legitima o papel do Supremo como meio para o alcance de fins relevantes lança mão de uma racionalidade instrumental, eficiente para desviar a atenção da problemática de ser o tribunal um órgão não eleito ${ }^{70}$. Afinal, "desde que as finalidades consideradas importantes sejam atingidas, a pergunta sobre quem as realizou adquire papel secundário.” Ademais, questões relativas à postura do tribunal, se mais contida ou mais ativista, também perdem espaço, “já que, quando elas são postas sobre a mesa, o apelo pragmático da realização de fins valiosos atua como espécie de trunfo capaz de obstruir o avanço da discussão de fundo”.

Buscando outra linha de argumentação, Eduardo Mendonça (2008) defende que a questão se resumiria a privilegiar um desenho institucional que, da melhor maneira possível, promovesse a democracia em sua versão substancial. Para este autor, haveria inegável vantagem na existência de uma instância de controle das condições substantivas da democracia, formalmente separada do processo decisório original, que funcionaria como um canal para que sociedade pudesse forçar manifestações específicas sobre o atendimento às condições democráticas. Este canal não precisaria ser a jurisdição constitucional, podendo até ser uma instância instalada no interior do Poder Legislativo, mas Mendonça acredita que existem muitos fatores que recomendariam a introdução de controle

69 No mesmo sentido, Fernando Ângelo Leal (2017), reagindo à frase do ministro Luís Roberto Barroso, segundo a qual a jurisdição constitucional tem servido bem ao país, pergunta: "Mas o que define o que serve bem ao país? A Constituição por meio de seus compromissos genéricos e princípios vagos, que permitem não mais do que acordos gerais, mas são incapazes de servir como referência para a superação de desacordos particulares? Mas como lidar com a possibilidade real de um único meio realizar e restringir, ao mesmo tempo, estados de coisas almejados pela Constituição? O Supremo seria o responsável por aferir a proporcionalidade das suas próprias escolhas?

${ }^{70}$ No mesmo sentido: "Levar direitos a sério, todavia, pede que se pense não só sobre o seu conteúdo, sobre seu núcleo de origem, sobre as exigências do princípio da dignidade da pessoa humana. Satisfazer-se com quem quer que decida sobre seu significado (no caso, juízes) não se harmoniza com a democracia nem com os pressupostos morais que ela carrega” (MENDES, 2008, p.189). 
judicial. Sua composição por agentes não-eleitos não precisaria significar uma afronta ao processo democrático, tratando-se apenas de uma questão de opção de arranjo institucional. A demanda por equilíbrio entre soberania popular e direitos fundamentais no mundo contemporâneo exigiria que a legitimação democrática fosse combinada à legitimação discursiva para ter seus efeitos potencializados.

Graças a esta legitimação discursiva, o espaço público poderia ser definido como um sistema complexo de instâncias deliberativas e fóruns decisórios que devem estar submetidos permanentemente à influência e à crítica:

Nesse ambiente, qualquer reposta deve ser vista como essencialmente provisória, a despeito da conviç̧ão compartilhada sobre determinados valores básicos, como igualdade ou a liberdade. Até as decisões finais - por necessidade de superação de impasses - devem ser tomadas como provisoriamente finais. O Supremo Tribunal Federal pode mudar de ideia, uma lei ou ato do Executivo podem estabelecer diálogo com a decisão da Corte, uma emenda à Constituição pode ser aprovada, a própria Constituição pode ser substituída.

Nesse sentido, a premissa básica da legitimação discursiva seria de que os perdedores de determinado processo decisório teriam o direito fundamental de receber argumentos que não os desqualificassem como iguais participantes da comunidade decisória. Em outras palavras, esta legitimação seria responsável por impor limites à maioria através de argumentos que considerassem a perspectiva do outro, garantindo a efetivação de uma democracia substantiva.

A jurisdição constitucional, por sua vez, enquanto forma de manifestação desta legitimação discursiva apresentaria as seguintes vantagens: (i) constituiria instância neutra em relação às forças políticas, sendo que acomodações estratégicas de interesses não fariam parte de sua lógica normal de atuação, podendo ser denunciadas; (ii) estaria sujeita a um dever reforçado de fundamentação, expondo-se de forma privilegiada à crítica pública; (iii) seria uma instância desarmada de instrumentos políticos porque não poderia fazer campanha de mídia, comício ou populismo assistencialista. Por tais razões situar a decisão provisoriamente final nas mãos do Judiciário promoveria um equilíbrio verdadeiramente deliberativo.

Cláudio Pereira de Souza Neto (2002) também relaciona o processo decisório judicial com a legitimação da jurisdição constitucional, incorporando o pensamento habermasiano. Segundo o autor, a teoria contemporânea da decisão 
considera que a referência argumentativa a princípios pode dar racionalidade, “controlabilidade” e justeza às decisões judiciais. Para que a jurisdição constitucional se legitime, o ato jurisdicional não poderia ser visto como um ato de mera vontade, mas como um ato racionalizado dialogicamente: "somente as proposições normativas que passem por um debate público podem ser consideradas racionais” (2002, 337).

Na mesma linha, Gustavo Binenbojm observa que a principal contribuição da jurisdição constitucional não estaria na "verdade ou bondade de seus julgados”, mas sim na "forma pela qual eles energizam o diálogo público e incrementam o seu grau de racionalidade ${ }^{71 »}$ (2010, p.119).

Oscar Vilhena Vieira (2002, p.232), em abordagem parecida, defende que o papel de um tribunal com atribuições constitucionais é decidir em maior conformidade com uma ética de princípios do que como uma ética consequencialista. A corte deveria decidir com base na normatividade préestabelecida pelos demais poderes, manifestar plena obediência ao devido processo legal e se submeter ao imperativo da imparcialidade. A função do tribunal seria buscar, através de um processo de argumentação racional, a decisão que melhor atenda aos princípios de justiça articulados na Constituição. Já o Legislativo e o Executivo, embora também submetidos à Constituição, poderiam atuar com um âmbito maior de discricionariedade, podendo, inclusive, mudar as regras do jogo. Além disso, se submetem à regra da maioria, o que pressupõe barganhas e compromissos, não sendo, portanto, imparciais. O autor conclui:

Ao assegurar a vontade da Constituição o Supremo Tribunal Federal realiza o ideal do governo das leis. Caso se afaste da vontade da Constituição, substituindo-a pela de seus próprios Ministros, estará agindo ilegitimamente, pois afinal não foram eleitos para assumir este tipo de função e sequer a Constituição assegurou ao tribunal tais atribuições. Ao Supremo Tribunal Federal, no entanto, cabe a última palavra. Daí decorre a sua enorme responsabilidade. (2002, p.233)

A literatura mais moderna, contudo, pretende superar a discussão em torno da supremacia do Judiciário, eliminando a ideia de última palavra. Nesta concepção, o controle de constitucionalidade deveria ser compreendido como parte de um processo de diálogo entre poderes, sempre aberto a novos

\footnotetext{
${ }^{71} \mathrm{O}$ autor continua o trecho citado, afirmando: “Acreditamos que os juízes possam fazê-lo melhor, atuando de forma paralela e complementar aos agentes políticos eleitos, por razões de filosofia política, mas também por razões empíricas e históricas.” (2010, p.119)
} 
argumentos, seja por parte do Legislador, seja por parte dos tribunais (SILVA, 2012). Assim, considerando que "nem os juízes nem os legisladores de carne e osso apresentam, em sua plenitude, as capacidades que as teorias lhe atribuem” (BRANDÃO, 2012, p.208), o sentido da Constituição deveria ser o resultado de uma complexa interação entre os Poderes Públicos e entre eles e a sociedade civil.

A Teoria dos Diálogos Institucionais se revelaria como mais interessante porque reconheceria a falibilidade das instituições, pregando que as melhores respostas seriam dadas a partir de um processo deliberativo contínuo:

Com efeito, se os demais "poderes" - especialmente o Legislativo - têm instrumentos para reagir a decisões de inconstitucionalidade indesejadas, o debate sobre o sentido futuro da Constituição não se restringe às Cortes, nem muito menos se encerra com a decisão judicial. Ao contrário, há um colóquio contínuo entre os Poderes do Estado e entre eles e a sociedade civil, circunstância que confere accountability à interpretação judicial da Constituição, na medida em que sincroniza com a opinião pública e com as preferências de maiorias políticas. Essas novas formas de se prover accountability à atuação judicial ganham relevância, na medida em que, com a cada vez menor vinculação do juiz a normas prévias e claras, a atuação judicial precisa manter referibilidade à vontade do povo, para preservar a sua neutralidade política. (BRANDÃO, 2012, p.221)

Entretanto, atestar a legitimidade da jurisdição constitucional com base na Teoria dos Diálogos Constitucionais apresenta alguns problemas. O primeiro deles se refere ao fato de que a possibilidade de revisão de uma decisão não elimina os custos de seus efeitos. Conrado Hübner Mendes, cuja tese de doutorado tratou do tema, reconhece que, mesmo que não exista o direito a "errar por último”, os erros têm custos:

A invocação da idéia de "última palavra provisória” não pode esconder o custo temporal, material e intelectual de novas "rodadas procedimentais”. Há graus de provisoriedade. Decisões, mesmo que possam ser revistas, são mais ou menos duradouras e resistentes. Alguns de seus efeitos se consumam e, em certo sentido, tornam-se irreversíveis. O fato de ser interlocutora, por essa razão, não significa que a corte esteja isenta da responsabilidade de boas decisões e de um teste rigoroso de legitimidade. (2008b, p.176)

Neste sentido, considerar os custos dos erros cometidos nos leva de volta à análise da instituição responsável pela decisão. Nesse ponto, há o segundo problema da definição da legitimidade democrática da jurisdição constitucional por meio dos diálogos institucionais: seria necessário definir quais características a capacitam como interlocutora adequada a produzir o sentido da Constituição. É 
que a referida teoria se apresenta como uma espécie de “meio termo" entre teorias de supremacia judicial e supremacia parlamentar, entretanto, para que se afirme como melhor opção dentre as duas, não pode evitar o interesse pelo comportamento das cortes e dos parlamentos. O desempenho destes atores irá, inevitavelmente, influenciar nas potencialidades dos debates produzidos acerca do sentido da Constituição. Logo, fica a pergunta subjacente: quais atributos devem os tribunais ostentar para permitir um “colóquio constitucional contínuo" proveitoso para a democracia?

De acordo com MENDES (2008b), as teorias de diálogos não fazem grandes demandas normativas sobre o tipo ideal de legislador ou de juiz, estando mais preocupadas em entender o significado de sua interação. Entretanto, como já afirmado anteriormente, não parece viável pensar no resultado de um debate sem antes refletir sobre as características de seus interlocutores, afinal, participantes autoritários, por exemplo, poderiam tornar o próprio diálogo inviável. Em outro trecho, o autor toca nesta questão:

O fato do diálogo, por si só, não fornece uma justificativa positiva para a existência da revisão judicial (independentemente de todas as outras formas imagináveis). Claro que poderíamos especular uma instituição ideal que desempenhasse, eventualmente, a função da revisão de maneira mais legítima e competente que a corte. Talvez a corte não tenha os melhores incentivos ou a capacidade para cumprir o papel que a teoria da legitimidade esboçada nessa tese lhe atribui. Mas abrir a janela para imaginar outras instituições exigiria seguir caminho diferente do escolhido aqui” (2008b, p.180).

Em razão disso, este autor se propõe a observar o modelo vigente "sob a melhor luz possível” como forma de estabelecer o ponto de partida. Pensar as condições de legitimidade do tribunal seria "estratégia mais fecunda que rejeitar, por princípio, a possibilidade da existência de uma instituição que nas últimas décadas ocupou um espaço antes inimaginável na estrutura de poderes.” (2008b, p.180)

Como se nota, há uma certa circularidade no argumento que acaba retornando aos fundamentos de legitimidade das cortes constitucionais para justificá-las como interlocutoras dos diálogos institucionais. A saída encontrada por Mendes para a questão da legitimidade está em relacioná-la à produção de razões de qualidade. Neste sentido, a corte cumpriria seu papel ao fazer com que o 
bom argumento se tornasse uma "variável de peso na competição democrática»72 (MENDES, 2008b, p.208).

Já para Brandão (2012), que também advoga a tese dos Diálogos Institucionais, o que qualificaria a jurisdição constitucional como interlocutora são os seguintes aspectos: o insulamento político (decorrentes das garantias da magistratura e da autonomia financeira e administrativa concedida ao Judiciário); o dever de fundamentação de suas decisões a luz do direito; o exame da constitucionalidade da lei após a sua edição e, via de regra, com mais informações sobre os efeitos concretos de sua aplicação do que o legislador tinha ao editá-la.

Diante dos argumentos expostos acima, poderíamos extrair alguns indicadores para avaliação da atuação do STF, ou seja, alguns parâmetros que funcionassem para sinalizar se a jurisdição constitucional, enquanto canal de processamento democrático, estaria cumprindo satisfatoriamente suas funções, apresentando vantagens significativas em relação a outros desenhos institucionais que privilegiassem outros tipos de arranjos:

1) Grau de neutralidade em relação às forças políticas: o STF tem sua independência assegurada pelas garantias da magistratura e pela autonomia financeira e administrativa (BRANDÃO, 2012), não podendo se revelar comprometido com a defesa de determinado grupo de interesses, como ocorre na classe política. Acordos políticos constituiriam desvio na função jurisdicional e deveriam ser denunciados (MENDONÇA, 2008);

2) Qualidade da fundamentação das decisões: os juízes estariam submetidos a uma exigência argumentativa muito mais intensa do que os agentes políticos, devendo se limitar aos argumentos de razão pública, ou seja, sem invocar sua própria moral ou seus pontos de vista religiosos ou filosóficos. Desse modo, permitiriam uma exposição privilegiada à crítica pública (MENDONÇA, 2008). A corte cumpriria o seu papel ao incrementar o debate público com razões de qualidade (MENDES, 2008b). Apesar da inexorável dimensão política da interpretação constitucional, ela constitui tarefa jurídica, estando sujeita, portanto,

${ }^{72}$ Em outro trecho, o autor irá concluir que: "Legitimidade política é um predicado institucional volátil, que dependerá, em parte dos resultados, e não somente das credenciais prévias. É uma meta a ser conquistada e conservada, a cada decisão. Esboçar uma escala de critérios qualitativos que permitam mensurá-lo é, nesse sentido, uma tarefa fundamental da teoria democrática. O desempenho deliberativo pode ser tal princípio regulador das oscilações entre corte e parlamento.” (MENDES, 2008b, p.213) 
aos cânones de racionalidade, objetividade, motivação, devendo reverência aos princípios de interpretação e aos precedentes (BARROSO, 2009; BINENBOJM, 2010, VIEIRA, 2002);

3) Quantidade de recursos políticos à sua disposição: os membros do tribunal não disporiam dos mesmos instrumentos da política-partidária, não podendo lançar mãos de armas políticas tradicionais como medidas populistas ou realizar campanha na mídia para garantir o apoio da opinião pública (MENDONÇA, 2008).

Ante o exposto, no capítulo seguinte, aplicaremos estes indicadores a algumas situações concretas vivenciadas no passado recente pelo Supremo Tribunal Federal e por seus membros na tentativa de aferir se o papel exercido por ele, considerando os diversos níveis de sua atuação e intervenção política, são compatíveis com os ideais de legitimação e aperfeiçoamento democráticos acima expostos. 


\section{4 \\ Parâmetros para a crítica da atuação do STF}

\section{1. \\ Grau de neutralidade em relação às forças políticas}

Luís Roberto Barroso (2012) afirma que "poucas críticas são mais desqualificantes para uma decisão judicial do que a acusação de que é política e não jurídica”. Segundo ele, “juízes não são seres sem memória e sem desejos, libertos do próprio inconsciente e de qualquer ideologia e, consequentemente, sua subjetividade há de interferir com os juízos de valor que formula.” Contudo, assumir que a neutralidade não se concretizará em sua plenitude, não autorizaria que o juiz proferisse decisões tendenciosas ou partidarizadas ${ }^{73}$. O dever de motivação, mediante o emprego de argumentação racional e persuasiva, seria o traço distintivo da função jurisdicional e permitiria o controle das hipóteses em que o juiz estaria agindo por vontade política própria.

Outro aspecto relativo à neutralidade, salientado por Eduardo Mendonça (2008), é que, “na política, acordos são inevitáveis e podem gerar acomodações estratégicas, ainda que haja exigências mínimas e controle público.” Já do Judiciário, se poderia cobrar decisões sem este tipo de vinculação, pois ele deveria tratar "cada caso com uma exigência autônoma de aplicação adequada da ordem jurídica.” Sendo regida por esta lógica, a instância jurisdicional apresentaria uma vantagem em relação aos demais poderes regidos pela sistemática da política partidária. Ela não estaria imune a desvios, mas, nesta hipótese, eles poderiam ser denunciados, cabendo à crítica pública exercer este tipo de fiscalização.

\footnotetext{
73 Para Barroso (2009): “A pretensão de neutralidade do intérprete, embora seja passível de atendimento no que toca à sua imparcialidade e impessoalidade, é inatingível na sua plenitude. Interpretar envolve, freqüentemente, a escolha de valores e de alternativas possíveis. Ainda quando não atue movido por interesses de classe ou estamentais, ainda quando não milite em favor do próprio interesse, o juiz estará sempre promovendo as suas crenças, a sua visão do mundo, o seu senso de justiça.”
} 
Portanto, para atender a este parâmetro de legitimação - a neutralidade as decisões judiciais, mesmo que influenciadas pelas crenças e ideologias dos julgadores, não poderiam ser baseadas explicitamente em preferências pessoais dos membros do tribunal e nem refletir acomodações estratégicas. Mas será que isto basta quando estamos argumentando que a decisão proferida pela jurisdição constitucional apresenta vantagens, enquanto instância de controle, sobre decisões a serem proferidas por instituições inseridas no contexto da política tradicional? Apresentar uma motivação jurídica razoável supre quaisquer questionamentos sobre as razões que influenciaram a tomada de determinada decisão? A neutralidade não seria uma preocupação de ordem normativa, mas de difícil verificação empírica em um cenário que confunde política e direito (FRIEDMAN, 2006)?

Nuno Garoupa (2016, p.9) resume a questão da seguinte forma:

Podemos concluir que cada corte constitucional exibirá, portanto, duas importantes dimensões políticas: política judicial (em um esforço para expandir suas competências, ampliar prestígio e adquirir supremacia sobre outros tribunais) e política partidária (no sentido de promover objetivos ideológicos). Em regimes democráticos, a política judicial necessariamente cria pressão institucional para que a corte adote uma fachada apolítica e produza jurisprudência coerente. Avançar em metas ideológicas divide a corte e politiza suas decisões. Consequentemente, a tensão entre política judicial e partidária é inevitável. ${ }^{74}$

Conforme exposto no capítulo I, quando a atuação do órgão de cúpula do Judiciário é observada sob a perspectiva da ciência política, outras variáveis são incorporadas à análise e somos forçados a considerar que se, por um lado, os ministros do STF são constrangidos pelo que determinada a lei, por outro, eles passam por um processo político de nomeação, precisam decidir em conjunto com os outros membros da corte e não possuem mecanismos para forçar o cumprimento de suas decisões, o que faz com que considerem a possível resposta dos demais atores políticos e da opinião pública antes de assumir determinados

\footnotetext{
${ }^{74}$ Tradução da autora: "We can conclude that each constitutional court will therefore exhibit two important political dimensions: judicial politics (in an effort to expand competences, enhance prestige, and achieve supremacy over the higher courts) and partisan politics (in the sense of advancing ideological goals). In democratic regimes, judicial politics necessarily creates peerpressure within the court to comply with an apolitical façade and provide a coherent body of case law. Advancing ideological goals divides the court, and politicizes the court's decisions. Hence, the tension between judicial and partisan politics is inevitable.”
} 
posicionamentos. Acomodações estratégicas, portanto, farão parte de sua dinâmica institucional, mesmo que não reveladas como no campo da política partidária.

A literatura norte-americana tem se aprofundado no estudo sobre comportamento judicial, discutindo os fatores que influenciam na tomada de decisão e construindo modelos a partir de determinadas chaves explicativas, como, por exemplo, a ação estratégica, a ideologia política ou a tradição legal (FRIEDMAN, 2005). Diana Kapiszewski (2011) parte destes modelos já construídos para defender a tese de que, em democracias desenvolvidas ou em desenvolvimento, os juízes, além de observarem o conteúdo de cada caso politicamente relevante e o contexto em que será decidido, ponderam estrategicamente seis considerações: (i) a sua própria ideologia; (ii) os interesses institucionais do Judiciário; (iii) as preferências dos representantes políticos eleitos; (iv) as possíveis consequências políticas e econômicas da sua decisão; (v) a opinião pública sobre o caso; e (vi) a lei e os aspectos jurídicos ${ }^{75}$.

Como compatibilizar, então, a exigência de neutralidade e uma teoria que integre direito e política ${ }^{76}$ ? Como aferir o grau aceitável de vinculação de uma

\footnotetext{
${ }^{75}$ Conrado Hübner Mendes, em sua tese de doutorado, resume a questão: “Se, por um lado, o mito da neutralidade judicial já foi quebrado há bastante tempo por diferentes escolas, o da independência judicial sobrevive e continua ignorado pela teoria normativa (seja pelos que a celebram, seja pelo que lamentam e criticam sua ilegitimidade democrática). Muitos admitem que o juiz decida conforme conviçcões políticas e ideológicas. Dworkin, por exemplo, constrói sua teoria da leitura moral da constituição e do direito como integridade a partir dessa premissa (o que não significa, para ele, que não existam outros limites da razão). Não aceitam ou não notam que o comportamento judicial seja determinado, contudo, por constrangimentos políticos externos. Ou seja, se a corte é cercada por todo um aparato procedimental para garantir independência em relação à política eleitoral, o juiz está limitado, para os mais otimistas, unicamente pelo direito, e, para outros nem isso. Três teses defendidas pela ciência política empírica sobre o comportamento judicial rompem esse segundo mito. Não pretendo entrar nas variações e na sofisticação dos variados modelos de análise existentes. Registro apenas o mínimo que ele compartilham: (i) a corte é politicamente sensível e testa, de modo ininterrupto, o espaço que pode ocupar na separação de poderes a partir do cálculo da resposta potencial dos outros poderes às suas decisões, e de sua força e capacidade para resistir; (ii) a separação de poderes é um fenômeno dinâmico, e uma norma jurídica abstrata não tem como descrever ou capturar essa constante redistribuição de fronteiras; (iii) em parelho a essa interação, a própria legitimidade de cada participante do jogo também oscila, e tal oscilação é responsável, inclusive, pelo espaço maior ou menor que o poder irá ocupar no arranjo de forças.” (2008, p.190-191)

${ }^{76}$ Como observado por Arguelles e Ribeiro (2013), o próprio desenho institucional e arranjos de controle de constitucionalidade tornam problemática a tarefa de definir e separar o que é direito e o que é política: "Por isso, qualquer modelo de comportamento dos Ministros do Supremo que parta de uma separação forte entre o que é interpretação constitucional e o que é preferência política tem sobre si um ônus da prova significativo, pois a definição dessas categorias e da relação entre elas precisa partir dos dados institucionais básicos de que os Ministros (i) têm o poder político de fazer valer normas constitucionais, e, por isso mesmo, (ii) são indicados politicamente.”
} 
decisão a outros tipos de influência que não o ordenamento jurídico? Em outras palavras, em que medida uma motivação extrajurídica passa no teste da neutralidade?

Estas são indagações de difícil resposta, até porque não é fácil demonstrar qual a motivação predominante diante do caso concreto: como medir o peso exato da ideologia e dos fundamentos jurídicos? Como garantir que o direito funcionou apenas como mera racionalização para fazer valer preferências pessoais ou estratégias institucionais?

Diante disso, poderíamos afirmar que a neutralidade com relação às forças políticas não seria um bom critério para atestar a legitimidade da jurisdição constitucional ou sua superioridade como modelo de controle de poder. No entanto, conforme já mencionado anteriormente neste trabalho, a performance política do STF não se limita à decisão final proferida, mas alcança o conjunto de suas práticas e de seus ministros. Se pode ser difícil definir quais motivações predominaram para a tomada de determinada decisão ou incerto afirmar que o resultado do julgamento satisfez os parâmetros mínimos de neutralidade que conferem legitimidade à jurisdição constitucional, a realidade pode ser outra na avaliação mais ampla das condutas do tribunal e de seus membros individualmente considerados. Será que o personagem político que o tribunal construiu atende a estes parâmetros? Nesse sentido, a exigência de uma postura neutra poderia funcionar como um freio para determinadas práticas que, apesar de não serem vedadas por lei, iriam de encontro a este ideal.

Um exemplo deste tipo de prática ocorre quando os ministros resolvem expressar suas críticas ou preferências de natureza político-partidária, chegando a opinar abertamente sobre casos que estão sob apreciação do Supremo ou serão, muito provavelmente, a ele submetidos. Esta atitude poderia ser caracterizada como manifestação de poder "informal” dos membros do tribunal, uma vez que seu estatuto jurídico não está claramente definido (ARGUELLES \& RIBEIRO, 2015). Apesar de a expressão de opinião sobre processos pendentes de julgamento 
encontrar vedação no art.36 da Lei Orgânica da Magistratura (LOMAN), a própria aplicabilidade desta lei aos ministros do STF é objeto de controvérsia ${ }^{77}$.

Nesse passo, os ministros do Supremo comumente tornam públicas suas posições ideológicas sem aparentar maiores preocupações com as possíveis repercussões. Foi que o ocorreu em 31.03.2016, quando, já iniciados os trabalhos da comissão de impeachment da Presidente Dilma Rousseff perante a Câmara dos Deputados, o ministro Luís Roberto Barroso, dando uma palestra na Fundação Lemann, declarou: "Quando anteontem o jornal exibia que o PMDB desembarcou do governo e mostrava as pessoas que erguiam as mãos, eu olhei e disse: 'Meu Deus do céu! Essa é nossa alternativa de poder’. Não vou fulanizar, mas quem viu a foto sabe do que estou falando"78.

Já o ministro Marco Aurélio, falando a jornalistas em 30.03.2016, afirmou:

Acertada a premissa [isto é, se não houver crime de responsabilidade], ela tem toda razão. Se não houver fato jurídico que respalde o processo de impedimento, esse processo não se enquadra em figurino legal e transparece como um golpe.

$(\ldots)$

\footnotetext{
${ }^{77}$ Em artigo do Jota, Diego Werneck Arguelles discute a postura dos ministros do STF no que se refere à aplicabilidade da LOMAN e ao controle do CNJ. Para o autor, o problema não reside apenas na questão da submissão ou não dos ministros aos dispositivos da lei, mas no recado que o Supremo passa aos demais magistrados: "Há, porém, uma segunda leitura possível. Mais ampla e problemática para a governança do judiciário. Em vez da excepcionalidade do Supremo, ela enfatiza o que ministros e juízes têm em comum. Afinal, não são todos magistrados? Mesmo que os ministros do Supremo acreditem que a LOMAN não se aplica a eles, seus colegas de togas no resto do país podem ouvir uma mensagem distinta - a de que a independência judicial se confunde com falta de controle e de limites para sua conduta fora dos autos. Esse risco não é teórico. Ainda precisamos consolidar entendimentos sobre os padrões éticos e profissionais da magistratura. $\mathrm{O}$ Juiz Moro foi criticado por se manifestar fora do autos; a Associação Juízes para a Democracia (AJD), por sua vez, foi criticada por ter se manifestado em repúdio a uma decisão do próprio Juiz Moro. A LOMAN é antiga e precisa de reforma, mas é o único parâmetro que temos para equacionar esses conflitos. Enquanto não elabora a nova LOMAN, o Supremo precisa defender a atual." (Disponível em: <https://jota.info/colunas/supra/afinal-ministro-do-supremo-e-magistrado15032016>, acesso em: 23 mai. 2017).

Ainda sobre o assunto, o jornal El País publicou, em 17.07.2016, matéria destinada a discutir as polêmicas em torno dos julgamentos do Supremo, em que especialistas comentavam aspectos como os pedidos de vista, o timing da corte, antecipação de voto pelos ministros, dentre outros assuntos. No que diz respeito a este último ponto, a assessoria do STF encaminhou nota ao jornal, esclarecendo que é vedado aos juízes: "manifestar, por qualquer meio de comunicação, opinião sobre processo pendente de julgamento, seu ou de outrem, ou juízo depreciativo sobre despachos, votos ou sentenças, de órgãos judiciais, ressalvada a crítica nos autos e em obras técnicas ou no exercício do magistério". Ainda de acordo com a assessoria, a responsabilização dos ministros "no caso de infrações de natureza político-administrativa, compete ao Senado Federal". (Disponível em:

<http://brasil.elpais.com/brasil/2016/06/10/politica/1465591620_578341.html?id_externo_rsoc=F B_CM>. Acesso em: 03 out. 2016.)

${ }_{78}$ Notícia extraída do sítio G1: http://g1.globo.com/politica/noticia/2016/03/meu-deus-do-ceu-dizbarroso-sobre-pmdb-como-alternativa-de-poder.html. Acesso em: 11 abr. 2016.
} 
Após o impedimento o Brasil estará melhor? O que nós teremos após o impedimento? A situação é diversa de 1992 porque temos dois segmentos que se mostram a esta altura antagônicos, e não queremos conflitos sociais. Queremos a paz social.

(...)

O Judiciário é a última trincheira da cidadania. E pode ter um questionamento para demonstrar que não há fato jurídico, muito embora haja fato político, suficiente ao impedimento. ${ }^{79}$

Percebe-se que o ministro não se furtou de atuar como comentarista político, fazendo previsões sobre o futuro do processo de impeachment e apresentando suas convicções sobre o que seria melhor para o país. Além disso, deixou claro seu entendimento de que o STF poderia rediscutir o mérito de uma eventual decisão parlamentar desfavorável à Presidente Dilma Rousseff.

O ministro Gilmar Mendes, por sua vez, em meio à sessão de julgamento do dia 16.03.2016, em um discurso político inflamado, criticou a nomeação de Luiz Inácio Lula da Silva para a chefia da Casa Civil, afirmando que a medida configuraria tentativa de fuga da investigação da Lava Jato. Em seguida, concluiu que, depois da divulgação do conteúdo da delação premiada do Senador Delcídio Amaral, que associou o ex-presidente ao comando do "Mensalão", ser alçado a chefe de governo seria "uma condição de uma bizarrice que nos enche de vergonha”80. Dois dias depois (18.03.2016), Gilmar Mendes suspendia a nomeação de Lula em liminar em Mandado de Segurança $n^{0} 34.071$ impetrado pelo PSDB e pelo PPS.

Em casos como estes, a ideia de neutralidade é afetada não só pela possível parcialidade nas decisões a serem proferidas, mas também porque estas condutas podem indicar uma disposição dos ministros de interferir do jogo político de forma mais proeminente, contrariando o mito da inércia judicial. Ao se manifestar publicamente afirmando que o mérito do processo de impeachment pode ser apreciado pelo STF, o ministro Marco Aurélio passou um recado aos atores externos ao tribunal, estimulando a judicialização da questão. O discurso de Gilmar Mendes, por outro lado, acabou por incentivar os opositores da Presidente

\footnotetext{
$79 \quad$ Disponível em: <http://g1.globo.com/politica/processo-de-impeachment-dedilma/noticia/2016/03/sem-fato-juridico-ministro-do-stf-diz-que-impeachment-transparece-comogolpe.html>. Acesso em: 11 abr. 2016.

80 Disponível em: <http:/g1.globo.com/politica/noticia/2016/03/mendes-compara-ida-de-lulapara-ministerio-nomeacao-de-empreiteiro.html>. Acesso em: 16 abr. 2016.
} 
a ajuizarem diversas ações contra a nomeação do ex-presidente Lula para a chefia da Casa Civil, de modo a aumentar suas chances na relatoria. E foi o que, de fato, aconteceu. Como as demandas de controle concentrado se submetem à distribuição específica, houve uma dupla prevenção sobre a questão: ao ministro Teori Zavascki, couberam as arguições de descumprimento de preceito fundamental e, ao ministro Gilmar Mendes, as demais ações. Enquanto o ministro Teori, analisando a ADPF $\mathrm{n}^{0} 390$, solicitava informações à Presidência da República, com base no art.5º, parágrafo $2^{\circ}$, da Lei 9.882/99, Gilmar Mendes deferiu liminar no mandado de segurança contra a nomeação do ex-presidente Lula sem ouvir a autoridade impetrada. A decisão deste ministro desrespeitou o que determinam as Leis $n^{0} 8.437 / 92^{81}$ e $12.016 / 09^{82}$, e contrariou a precedência do controle concentrado sobre o incidental ${ }^{83}$ que o Supremo sempre preconizou ${ }^{84}$.

${ }^{81}$ Art. $2^{\circ}$. No mandado de segurança coletivo e na ação civil pública, a liminar será concedida, quando cabível, após a audiência do representante judicial da pessoa jurídica de direito público, que deverá se pronunciar no prazo de setenta e duas horas .

${ }^{82}$ Art. $7^{\circ}$. Ao despachar a inicial, o juiz ordenará:

I - que se notifique o coator do conteúdo da petição inicial, enviando-lhe a segunda via apresentada com as cópias dos documentos, a fim de que, no prazo de 10 (dez) dias, preste as informações;

II - que se dê ciência do feito ao órgão de representação judicial da pessoa jurídica interessada, enviando-lhe cópia da inicial sem documentos, para que, querendo, ingresse no feito;

III - que se suspenda o ato que deu motivo ao pedido, quando houver fundamento relevante e do ato impugnado puder resultar a ineficácia da medida, caso seja finalmente deferida, sendo facultado exigir do impetrante caução, fiança ou depósito, com o objetivo de assegurar o ressarcimento à pessoa jurídica.

83 Seria possível argumentar que, nesta hipótese, a ADPF não representaria um exemplo de controle abstrato de constitucionalidade, já que discutia um decreto específico de nomeação para a Casa Civil. Inclusive, posteriormente, as ADPFs ajuizadas neste caso não foram conhecidas, sob o argumento de que existiam outros mecanismos aptos a impugnar o ato. Entretanto, acredita-se que cabia ao ministro Gilmar Mendes, por medida de cautela, considerando a forte repercussão política do caso, seguir a regra geral e aguardar a manifestação do ministro Teori Zavascki.

${ }^{84}$ Sobre esta jurisprudência do STF:

EMENTA AGRAVO REGIMENTAL EM AÇÃO CAUTELAR. CONCESSÃO DE EFEITO SUSPENSIVO. ADMISSIBILIDADE DO APELO EXTREMO NÃO APRECIADA PELO TRIBUNAL A QUO. INCOMPETÊNCIA DO SUPREMO TRIBUNAL FEDERAL PARA APRECIAR A AÇÃO CAUTELAR INCIDENTAL. ART. 880 DO CPC. SÚMULAS 634 E 635 DO STF. 1. Ainda não examinada a admissibilidade do recurso extraordinário interposto no processo principal, sequer resulta instaurada a jurisdição desta Corte Suprema e, consequentemente, a teor do art. 800 do CPC, tampouco lhe compete apreciar ação cautelar incidental ao processo no qual interposto aquele apelo, devendo ser prestada a tutela cautelar pelo Tribunal a quo. Súmulas 634 e 635 do STF. 2. Não houve negativa de prestação jurisdicional pelo Tribunal a quo. Com efeito, observadas as Súmulas 634 e 635 do STF, o Vice-Presidente do Tribunal Regional Federal da $2^{\text {a }}$ Região consignou ser competente para análise da medida cautelar inominada solicitada pela requerente, tendo examinado e indeferido o pedido respectivo. 3. Não está configurada situação excepcional, suscetível de afastar, no caso, o entendimento consolidado nos referidos verbetes sumulares, pois, ante a precedência do controle concentrado em relação ao controle difuso, decidida em questão de ordem suscitada na ADC $n^{\circ}$ 18, na qual ainda não colhidos votos quanto ao mérito da inclusão do ICMS, embutido no cálculo por dentro do preço de mercadorias, no conceito de faturamento, para fins de incidência de PIS e COFINS, não há como antever a posição definitiva desta Corte sobre o tema, mormente considerada a substancial alteração de sua composição desde o pedido de 
Passou ao largo, também, do fato de que o PSDB era também o autor da ADPF distribuída ao ministro Teori, o que poderia caracterizar tentativa de burla ao juiz natural. Por fim, conseguiu que sua decisão tivesse efeitos prolongados no tempo, pois, na semana seguinte, ocorreriam os feriados da semana santa e, na posterior, ele estaria fora para um congresso internacional. ${ }^{85}$

Além da divulgação de posicionamentos político-partidários, outra prática que deveria ser colocada em discussão é aquela que diz respeito a reuniões de ministros, a portas fechadas, com atores políticos diretamente interessados no desfecho de julgamentos a serem realizados pelo Supremo. Foi o que aconteceu quando o ministro Gilmar Mendes se reuniu, no sábado 28.05.2016, com o então Presidente da República interino Michel Temer no Palácio do Jaburu em Brasília. A forma como jornal $\mathrm{O}$ Estado de São Paulo narrou o encontro dá a perfeita dimensão das suspeitas que a conduta suscitou:

BRASÍLIA - O presidente em exercício Michel Temer recebeu Gilmar Mendes, ministro do Supremo Tribunal Federal (STF) e presidente do Tribunal Superior Eleitoral (TSE), no Jaburu na noite desse sábado, 28. De acordo com a assessoria de Temer, a reunião foi agendada para tratar do orçamento do TSE. O presidente em exercício permanece em Brasília, mas não tem agenda pública nesse domingo, 29. Mendes, que foi advogado-geral da União durante o governo do ex-presidente Fernando Henrique Cardoso e é abertamente crítico do governo PT, é o relator no TSE do processo que analisa as contas da campanha e pode levar à cassação da chapa de Dilma Rousseff e Michel Temer.

Além disso, o ministro também vai assumir, na próxima terça-feira, 31, a presidência da Segunda Turma do STF, que é responsável pela maior parte dos inquéritos que investigam políticos na Operação Lava Jato ${ }^{86}$.

vista formulado pelo Ministro Gilmar Mendes no julgamento do RE 240.785/MG. 4. O perigo da demora inverso também desaconselha flexibilizações na abertura da jurisdição cautelar desta Suprema Corte, uma vez que, ante a tradicional jurisprudência do Superior Tribunal de Justiça acerca da inclusão do ICMS na base de cálculo do PIS e da COFINS (Súmulas 68 e 94/STJ), eventual manutenção, por tutela de urgência, desacompanhada de depósito em juízo ou outra garantia, da suspensão da exigibilidade dos créditos discutidos pela recorrente pode importar em impacto no quadro concorrencial, pois configuraria vantagem potencialmente não alcançável por outros agentes econômicos. 5. Por fim, caso queira manter suspensa a exigibilidade dos créditos discutidos, resguardando-se da incidência de multa de mora e encargos legais, a requerente pode, com esteio no art. 151, II, do CTN, promover o depósito do valor discutido, a fim de que, caso ao final seja vencedora, possa levantá-lo com os acréscimos devidos. Agravo regimental conhecido e não provido. (grifos meus) Ver mais em: AC 3643 AgR/RJ, Relatora Ministra Rosa Weber, julgado em 25 jun. 2014.

${ }^{85}$ Diego Werneck Arguelhes e Ivar A. Hartimann, em artigo intitulado "Mendes e Lula: uma liminar contra o Plenário do Supremo", publicado no blog Jota, advertem que a liminar do ministro erode a autoridade do plenário, pois "Mendes usurpou, na prática, o controle colegiado do timing", além de aumentar as dúvidas sobre a imparcialidade do tribunal.

86 Disponível em: <http://politica.estadao.com.br/noticias/geral,apos-encontro-com-gilmarmendes--temer-permanece-em-brasilia-sem-agenda-publica,10000054013>. Acesso em: 05 set. 2016. 
Considerando todos estes elementos levantados pela notícia acima reproduzida, não há como não concluir que o encontro do ministro com o Presidente, em um sábado à noite, depõe contra a expectativa de independência de Gilmar Mendes na análise dos processos de interesse de Temer em trâmite no $\mathrm{TSE}^{87}$, daqueles relativos ao impeachment de Dilma Rousseff e de ações relacionadas à Operação Lava-Jato em que seja réu. Como não existem regras disciplinando este tipo de conduta, a decisão sobre marcar este tipo de reunião fica a cargo dos ministros sem que ocorram maiores discussões, sob a perspectiva institucional, sobre os custos de sua adoção para a credibilidade do tribunal e a vantagem/necessidade destes encontros.

Outro aspecto que deve ser analisado quando pensamos na exigência de neutralidade em relação às forças políticas é aquele relativo ao poder de controle do tempo processual por parte dos ministros do STF. Ele pode ser observado, de uma maneira geral, através da velocidade com que são proferidas liminares, pela duração dos pedidos de vista e pela rapidez com que processos são incluídos em pauta para julgamento pelo plenário. Esta inclusão depende da liberação do voto pelo relator, sem que haja previsão de sanção para o caso de descumprimento dos prazos previstos no art.111, do Regimento Interno do tribunal. O MS 22.972, por exemplo, que havia sido impetrado contra atos da Mesa da Câmara dos Deputados destinados a apreciar a PEC 20/1995 (conhecida como PEC do parlamentarismo), chegou ao Supremo em 1997, teve a liminar negada e, desde então, aguardava por julgamento. Com o retorno do debate sobre parlamentarismo no Congresso, o tribunal incluiu o referido mandado de segurança em pauta para o dia 16.03.2016, bem em meio à grave crise institucional que o país enfrentava. O julgamento acabou por ser adiado para que o Senado Federal apresentasse suas informações no prazo de dez dias.

Sobre esta questão, Ivar Hartmann (2016) assinala que:

${ }^{87}$ O processo em tramitação no TSE foi ajuizado pelo PSDB para cassação da chapa Dilma Rousseff e Michel Temer em razão de irregularidades nas contas eleitorais. Em 16.09.2016, declaração do ministro Gilmar Mendes afirmando que dificilmente a ação será julgada em 2016 causou polêmica, já que, na hipótese de cassação da chapa em 2017, as novas eleições a serem convocadas seriam indiretas. Sentindo o peso desta responsabilidade, o ministro afirmou: "Eu sou apenas o presidente do tribunal. O ‘timing’ não é meu. Quando o relator disser que o processo está pronto para votar, eu ponho em pauta.” (Disponível em: <http://www1.folha.uol.com.br/poder/2016/09/1814894-acao-contra-dilma-e-temer-nao-deve-servotada-neste-ano-diz-mendes.shtml>. Acesso em: 21 set. 2016) 
O "timing” das decisões do plenário é um elemento decisivo e pouco conhecido pela sociedade. O Supremo pode decidir uma liminar em 20 horas (ADI 4.698) ou em 18 anos (ADI 1.229). Não há qualquer regra sobre isso. Não há nenhum mecanismo de freio ou contrapeso. Atualmente, o tribunal pode escolher se irá decidir o pedido de afastamento de Eduardo Cunha na semana que vem ou no final do ano.

Esta ausência de parâmetros gera inevitáveis suspeitas sobre a atuação do STF, que tende a parecer casuístico nas suas opções de prioridade de julgamento $^{88}$. O tempo da liminar e de apreciação pelo plenário podem revelar uma intervenção do tribunal (ou de um ministro individualmente) na política que vai mais além do conteúdo da decisão e alcança o próprio jogo e o timing mais típicos desta categoria. A inclusão em pauta de um processo parado por meses ou até por anos pode impor uma mudança radical e, às vezes, definitiva no cenário da política representativa.

Neste contexto, um caso que levantou questionamentos sobre a neutralidade do tribunal foi aquele relativo à antecipação de tutela concedida pelo Ministro Luiz Fux para a extensão do auxílio-moradia a toda a magistratura federal. A medida foi deferida na Ação Originária nº 1773 em 15.09.2014 e até o presente momento não foi submetida ao plenário. A decisão chegou a ser objeto do Mandado de Segurança $n^{\circ} 33.245$ impetrado pela União, que, contudo, não foi conhecido pela relatora, ministra Rosa Weber, diante do argumento de que não cabe mandado de segurança contra ato jurisdicional passível de recurso e que o recurso cabível, inclusive, já havia sido interposto. O Agravo Regimental protocolizado em outubro de 2014, porém, ainda aguarda apreciação.

O debate sobre este ponto é de especial relevância porque traz à tona o poder político que os ministros possuem de decidir o que decidir, atribuição esta

\footnotetext{
${ }^{88}$ Como afirmado por Ivar Hartmann, o caso do pedido de afastamento do Presidente da Câmara, Eduardo Cunha, é emblemático. Este pedido foi apresentado pelo Procurador-Geral da República em 16.12.2015 com o objetivo de assegurar a higidez da investigação criminal em curso contra o deputado, para garantir o regular andamento da instrução processual e aplicação da lei penal no que se refere à denúncia proposta contra o parlamentar. Na sua petição, o procurador também alega que a decisão sobre o afastamento de Cunha do mandato deve ser urgente para evitar que ele faça manobras e condutas para atingir seus "objetivos ilícitos". Em fevereiro de 2016, o deputado foi notificado para apresentação de defesa em 10 dias. Em março, o plenário do STF recebeu a denúncia contra ele no bojo do Inquérito ${ }^{0} 3983$. Em abril, diversas demandas chegaram ao STF questionando a legitimidade de Cunha para presidir o processo de impeachment da Presidenta Dilma Rousseff, no entanto, nenhuma incitou a Corte a reconhecer a urgência de sua manifestação sobre o pedido de afastamento formulado.
} 
que não decorre expressamente de nenhum texto legal, mas deflui, justamente, da ausência de regras que os restrinjam quanto a este aspecto:

Quando há regras e prazos claros que limitem essas escolhas, sobra pouca liberdade e, com ela, reduz-se também a margem para críticas. Mas quem pode escolher sua pauta sem qualquer critério institucional ou limite jurídico pode e deve ser criticado e responsabilizado, e não pode defender suas escolhas simplesmente invocando a lei.

\section{(...)}

O preço dessa liberdade é a eterna desconfiança pública quanto aos cálculos e estratégias por trás da formação da pauta. O Supremo é, hoje, suspeito quando corre, e suspeito quando freia. Seria possível minimizar esse problema reduzindo a liberdade dos relatores e do presidente do tribunal na formação da pauta, seguindo prazos muito claros para decidir. A Suprema Corte dos EUA, por exemplo, embora escolha livremente o que vai decidir, está sujeita a prazos claros uma vez que aceite julgar um caso. Não pode ficar em silêncio. Não pode adiar indefinidamente a decisão. Não pode improvisar a pauta. A decisão precisa ser dada no mesmo ano judicial em que ocorreu a sustentação oral (ARGUELLES, 2016).

Este poder do tribunal de optar por quais ações julgar não é necessariamente ruim, mas está, indiscutivelmente, associado ao aumento do juízo político à disposição da corte. Por isso mesmo, ele precisa ser amplamente debatido, principalmente, quando se manifesta de forma individualizada e não institucionalizada. Existem argumentos contra e a favor ${ }^{89}$ de conferir às cortes o controle de agenda, mas, quando este controle é exercido por cada ministro sem necessidade de consulta aos demais e sem regras claras, a questão se torna ainda mais complexa do ponto de vista do descompasso entre a dimensão do poder individual e as possibilidades de fiscalização de seu exercício ${ }^{90}$.

\footnotetext{
${ }^{89}$ David Fontana (2011) defende que o controle de agenda conduz a uma dinâmica política que auxilia as cortes no exercício da jurisdição constitucional. Ele funcionaria para que o tribunal pudesse intervir apenas na hora certa, contribuindo para a legitimação de sua atuação. Algumas questões constitucionais podem ser tão polarizadas que seu julgamento, em um momento particular ou a qualquer tempo, provocaria mais embates políticos que a corte poderia suportar. Por outro lado, este autor alerta para o perigo que este poder representa do ponto de vista do aumento da discricionariedade política dos tribunais. Um erro na estratégia adotada pode custar caro em termos de credibilidade e de capital institucional. Entretanto, a avaliação final é de que os aspectos positivos superariam os negativos, não havendo motivos para crer, na visão do autor, que os erros cometidos pelas cortes no exercício deste poder seriam fundamentais ou cruciais.

90 Na mesma linha, Conrado Hübner Mendes (2014) observa que: “Ainda que aceitemos tais ressalvas, e consideremos natural alguma margem de manobra estratégica no controle de constitucionalidade, não há boa justificativa para a prática do STF, por duas razões principais: em primeiro lugar, o tribunal permanece refém do poder de obstrução individual de cada ministro, que tem liberdade para abusar dessa competência impunemente; por esta razão, em segundo lugar, o STF se furta ao dever de construir uma estratégia propriamente institucional. A complacência da
} 
Outro exemplo de controle do tempo processual por um ministro de maneira isolada é a forma como são utilizados os pedidos de vista. Levantamento da Fundação Getúlio Vargas, divulgado pela Folha de São Paulo de 08.06.2015 ${ }^{91}$, mostra que só um de cada 5 pedidos deste tipo é devolvido no prazo regimental de duas sessões ordinárias. Considerando que não existem mecanismos para constranger um ministro a devolver o processo, a prerrogativa de pedido de vista torna-se um poder de veto, impedindo que determinadas questões sejam decididas. Suas motivações são, portanto, comumente colocadas em dúvida, como ocorreu no caso da ADI 4393, em que o ministro Luiz Fux pediu vista em maio de 2012 sem, que, até o presente momento, tenha sinalizado a intenção de devolver os autos para julgamento. Esta ação envolve a arguição de inconstitucionalidade de alguns dispositivos da Lei $n^{0} 5.535 / 09$, que trata da organização da magistratura fluminense. Dentre os artigos questionados, estão aqueles que preveem vantagens polêmicas como o auxílio-moradia e os 60 dias de férias para magistrados. $\mathrm{O}$ assunto, portanto, envolve relevantes interesses corporativos e passou a ter conexão mais direta com o ministro porque, em 2016, sua filha foi nomeada desembargadora do Tribunal de Justiça do Rio de Janeiro através da lista sêxtupla da $\mathrm{OAB} / \mathrm{RJ}^{92}$.

Os três pontos aqui levantados, antecipação de posições na imprensa, reuniões de ministros com atores políticos interessados em processos sob julgamento e o controle individual de timing têm em comum serem expressão de grande poder, ainda que de natureza informal, que cada ministro possui ${ }^{93}$. É forçoso concluir que este cenário que combina a inexistência de instrumentos de controle com enorme autonomia pessoal dos ministros não contribui para a crença de neutralidade no processo de tomada de decisão. Quanto mais liberdade, maior a

comunidade jurídica com tais hábitos enraizados a olhos vistos é um grande obstáculo a mudanças. Estrategicamente, o STF navega à deriva.”

${ }^{91}$ Disponível em: <http://www1.folha.uol.com.br/poder/2015/06/1638875-no-stf-so-20-dospedidos-de-vista-sao-devolvidos-no-prazo.shtml>. Acesso em: 05 set. 2016.

92 Em entrevista concedida no âmbito do projeto História Oral do Supremo da Fundação Getúlio Vargas, o ministro Fux justificou este pedido de vista da seguinte maneira: "Por exemplo: eu estou com um processo, que eu estou com vistas sobre determinados benefícios da magistratura; mas, ao mesmo tempo, eu fui designado para compor a lei orgânica da magistratura. Então, nós fizemos um trabalho de elaboração legislativa que, eventualmente, essas verbas discutidas podem ser verbas legitimadas na lei orgânica. Daí, a gente vai tirar, com efeito retroativo, depois vai dar?” (2016, p.114)

${ }^{93}$ Sobre este tema, ver ARGUELLES, Diego Werneck; RIBEIRO, Leandro Molhano. O Supremo Individual: mecanismo de atuação direta dos Ministros sobre o processo político. Revista Direito, Estado e Sociedade, n. 46, jan/jun 2015. 
margem para questionamentos. Se não existem parâmetros legais a se agarrar, como convencer que não estão adotando estratégia política ou de que não estão influenciados por forças desta natureza? E, neste caso, como defender que a decisão tomada pela corte constitucional possui mais valor que a decisão do Legislativo e do Executivo, que explicitam suas acomodações estratégicas? Mesmo que se argumente que o termômetro da credibilidade deve ser a opinião pública $^{94}$, é papel da academia apontar falhas no processo de legitimação da corte e sugerir mecanismos para limitação do poder.

A necessidade de imposição de limites aos ministros é, contudo, assunto delicado, que, comumente, precisa enfrentar a objeção de que este tipo de medida representa ameaça à autonomia da corte. Daniel Brinks (2005), entretanto, defende que esta ameaça não necessariamente é verdadeira, já que independência não significaria ausência de supervisão, mas a ausência de influência partidária unilateral. O que se contrapõe à independência judicial seria a parcialidade e não o controle sobre o poder judiciário, a accountability judicial, a supervisão sobre o processo de tomada de decisão ou qualquer outro meio de reduzir a escala de variação das decisões judiciais. Ainda segundo este autor, o Judiciário, como qualquer outra organização, precisa possuir mecanismos que garantam um certo grau de ortodoxia em decisões políticas. Em vista disso, ele propõe a seguinte tabela em que parcialidade se opõe à independência, podendo ambas conviver com diversos níveis de controle:

\footnotetext{
${ }^{94}$ Importante mencionar que, em 13.09.2016, o Senado recebeu dois pedidos de impeachment do ministro Gilmar Mendes, que acumula a função de presidente do TSE. Ambas as peças o acusam de adotar conduta partidária e parcial nos julgamentos das cortes. Um dos pedidos, assinado por juristas, atribui ao ministro crime de responsabilidade e elenca como condutas impróprias as manifestações públicas sobre processos, o uso de linguagem impolida, desrespeitosa ou indecorosa, o julgamento em casos em que seja suspeito ou impedido, a quebra de imparcialidade, o uso do pedido de vista como protelamento patentemente injustificado e o envolvimento em atividades político-partidárias. (Disponível em: <http:/www1.folha.uol.com.br/poder/2016/09/1813119-senado-recebe-pedidos-de-impeachmentde-gilmar-mendes.shtml>. Acesso em: 15 set. 2016).

Posteriormente, Renan Calheiros, presidente do Senado, determinou o arquivamento dos pedidos, mas esta decisão foi objeto de mandado de segurança no STF, alegando que a medida deveria ter sido submetida à Mesa Diretora do Senado. A relatoria do processo coube ao ministro Edson Fachin que, de início, não conheceu do pedido por entender que "não cabe ao Poder Judiciário, sobretudo em sede de mandado de segurança, controlar se as razões apresentadas pela autoridade senatorial processante (para arquivar uma denúncia) estão corretas ou não; isso seria contestável, a depender de regra interna da Casa, apenas em recurso, dentro da própria Casa Legislativa, mas não por outro Poder”. Esta decisão também foi objeto de recurso, que ainda depende de apreciação. (Disponível em: <https://oglobo.globo.com/brasil/fachin-mantem-processo-de-impeachmentcontra-gilmar-arquivado-no-senado-20891884>. Acesso em: 23 mai. 2017).
} 


\begin{tabular}{|c|c|c|}
\hline & AUTONOMIA & CONTROLE \\
\hline PARCIAL & PREFERÊNCIAS & PREFERÊNCIAS \\
\hline INDEPENDENTE & TOMADA DE DECISÃO & TOMADA DE DECISÃO \\
& TOMADA DE DECISÃO & TOMADA DE DECISÃO \\
& & POREFERÊNCIAS \\
\hline
\end{tabular}

Tabela 2

Segundo os conceitos estabelecidos por Brinks, “independência preferência” significa juízes não cooptados pelos mecanismos de sua nomeação e a "independência de decisão" se refere à ausência de influência no processo de tomada de decisão. Em democracias bem estabelecidas, com claros limites à interferência partidária nas cortes, pode ser que se prefira um grau relativamente alto de controle para permitir uma maior previsibilidade das decisões e prestigiar a segurança jurídica. Contudo, se há razão para temer a perda da independência, pode ser que se prefira um grau reduzido de controle, já que o potencial de influência sobre a corte cresceria na medida em que o nível de controle aumenta. Ao mesmo tempo, um alto grau de partidarismo associado a mecanismos de controle ineficientes produziriam um Judiciário que é o pior dos dois mundos: incontrolável e imprevisível em casos rotineiros e altamente parcial em casos importantes. Portanto, a questão se resumiria a este tipo de ajuste a ser pensado diante das especificidades do caso concreto.

Percebe-se, assim, que discutir mecanismos de controle sobre o Supremo Tribunal Federal não significa, necessariamente, ferir de morte sua independência e que reconhecer que o ideal de neutralidade seja talvez inalcançável não implica a impossibilidade de discutir as práticas de seus ministros que visivelmente suscitam dúvidas quanto à sua imparcialidade. A defesa da legitimidade da 
jurisdição constitucional não pode se dar ao preço de impedir o questionamento crítico, bem como a busca por aperfeiçoamento da atuação e dos instrumentos de prestação de contas do tribunal.

\section{2.}

\section{Qualidade da fundamentação das decisões}

Conforme já mencionado, existe um esforço teórico que busca legitimar a jurisdição constitucional com base na sua capacidade argumentativa. Ela apresentaria vantagem do ponto de vista da legitimação discursiva porque estaria sujeita a um dever reforçado de fundamentação, seria uma instância reflexiva e veiculadora da razão pública ${ }^{95}$ (MENDONÇA, 2008). Para Barroso:

Cabe retomar a ideia de democracia deliberativa, que se funda, precisamente, em uma legitimação discursiva: as decisões políticas devem ser produzidas após debate público livre, amplo e aberto, ao fim do qual se forneçam razões das opções feitas, por isso tem-se afirmado, anteriormente, que a democracia contemporânea é feita de votos e argumentos. Um insight importante nesse domínio é fornecido pelo jusfilósofo alemão Robert Alexy, que se refere à corte constitucional como representante argumentativo da sociedade. Segundo ele, a única maneira de reconciliar a jurisdição constitucional com a democracia é concebê-la, também, como uma representação popular. Pessoas racionais são capazes de aceitar argumentos sólidos e corretos. O constitucionalismo democrático possui legitimação discursiva, que é projeto de institucionalização da razão e da correção. (2015, p.40)

\footnotetext{
${ }^{95}$ Virgílio Afonso da Silva (2011) cita, como exemplo de argumento que baseia a legitimidade da jurisdição constitucional na qualidade da deliberação da corte, a posição de Rawls, segundo a qual a Suprema Corte seria o único órgão que tem o dever de justificar suas decisões com base na interpretação constitucional e em seus precedentes, diferentemente dos atos do Executivo e do Legislativo, que não carregariam este ônus. Em razão disso, o ideal da razão pública de amoldaria de forma especial ao Judiciário em detrimento dos demais Poderes.
} 
Segundo esta concepção ${ }^{96}$, a corte exerceria uma função representativa porque seria sensível à razão e não à vontade majoritária. A representação não seria de indivíduos particulares, mas se daria através da participação em um processo argumentativo no qual as posições de todos os possíveis interessados seriam consideradas. O controle sobre a qualidade deste processo argumentativo se daria a partir da análise da fundamentação da decisão e a fonte de legitimidade do poder parece estar em seu próprio exercício:

De forma análoga à legitimidade eletiva, o controle da atuação da Corte é feito da mesma maneira com que é adquirida a legitimidade: naquela pelo voto, nesta pela argumentação. Portanto, é através da fundamentação e dos motivos da decisão que a sociedade pode avaliar e aceitar o seu conteúdo, emprestando-lhe o reconhecimento democrático. Não é por outra razão que os litigantes vencidos, mas cujos argumentos foram satisfatoriamente apreciados pela decisão, reconhecem-lhe legitimidade (NETTO \& CAMARGO, 2010, p.1349).

Mas o que reivindicar de uma corte constitucional em termos de racionalidade decisória? Basta uma justificação pública baseada em princípios constitucionais? Não se pode esquecer que o argumento central é de que as cortes, apesar de seus membros não eleitos, representam esfera superior para a deliberação em relação às outras instâncias vinculadas à lógica da política eleitoral. Logo, é preciso que possamos identificar qual a contribuição judicial específica ao processo constitucional que não se limite ao "truísmo genérico de proteger a Constituição” (MENDES, 2012).

A questão da capacidade argumentativa pode ser analisada a partir de dois aspectos que estão intimamente relacionados entre si: sob o ângulo do processo deliberativo adotado e sob a ótica da qualidade dos fundamentos apresentados

96 Na mesma linha, ainda sobre a questão da representação argumentativa, Luiz Guilherme Marinoni acrescenta que: "Mas a compreensão da existência destas duas formas de representação não resolve o problema. Se a jurisdição detém a representação argumentativa em benefício da sociedade e em defesa dos direitos fundamentais, mas a representação política está consubstanciada na lei, é necessário que a representação argumentativa supere a representação política. Nessa perspectiva a democracia não se resume apenas a um processo de decisão marcado pela existência de eleições periódicas e pela regra da maioria. Um conceito adequado de democracia deve envolver não somente decisão, mas também discussão . A inclusão da discussão no conceito de democracia torna a democracia deliberativa. Trata-se de uma tentativa de institucionalizar o discurso tanto quanto possível como um instrumento para a produção de decisões públicas. Essa dimensão discursiva da democracia é exercida pela representação argumentativa, e é nela que se situam as bases da convivência política legítima. O controle judicial de constitucionalidade da lei se justifica quando os juízes demonstram publicamente que seus julgamentos estão amparados em argumentos que são reconhecidos como bons argumentos, ou, ao menos, como argumentos plausíveis, por todas aquelas pessoas racionais que aceitam a Constituição.” 
como razão de decidir. A premissa da corte constitucional como locus da razão pública depende da utilização de um método de deliberação racional que, por sua vez, permitirá apresentação de melhores fundamentos para a solução do caso concreto. Além disso, os procedimentos utilizados na tomada de decisão definirão a corte enquanto atriz do cenário político: como uma instituição ou como onze ilhas ${ }^{97}$ ?

Virgílio Afonso da Silva (2013, p.564) aponta que uma das grandes diferenças da deliberação no âmbito de cortes constitucionais em comparação ao Legislativo é que, no parlamento, o objetivo é ganhar e a argumentação dispendida não tem como função precípua convencer a oposição (que não estaria realmente disposta a mudar de posição), mas convencer a sociedade, os eleitores e a mídia de que a sua perspectiva é a correta. Já no que diz respeito à jurisdição constitucional, existiria um potencial deliberativo baseado na concepção de que, nesta seara, as informações seriam livremente compartilhadas, os participantes procurariam trabalhar como um time para atenuar os efeitos da racionalidade limitada, estariam abertos a novos argumentos, dispostos a mudar de opinião quando confrontados por melhores razões e, acima de tudo, estariam buscando o consenso.

97 Imagem utilizada por Conrado Hübner Mendes (2010) para expressar a dificuldade de identificar uma posição do STF enquanto instituição sobre os temas julgados: "Se tentarmos levar os argumentos do STF a sério, porém, esbarramos numa outra dificuldade: argumentos 'do tribunal' quase nunca existem, exceto por obra de uma metáfora. Não há, exceções à parte, razões compartilhadas pela maioria dos ministros, razões que, boas ou ruins, pudéssemos generalizar como do tribunal. Se perguntarmos por que o STF decidiu um caso numa determinada direção, não raro ficamos sem resposta. Ou melhor, ficamos com muitas respostas que nem sequer conversam entre si, expressas nos votos dos 11 ministros.” Virgílio Afonso da Silva (2015) também realizou estudo envolvendo o papel do ministro relator nas deliberações, verificando que, nos casos de destaque, os ministros tendem a levar seus votos já prontos e que não é comum que o relator divulgue seu voto para os demais ministros antes da sessão de julgamento, permitindo a eles uma preparação para debatê-lo. Ambas as práticas atrapalhariam a performance deliberativa do tribunal. Esta concepção, entretanto, foi posta em discussão por Almeida e Bogossian (2016) que defendem a tese de que o relator exerceria o papel de unificador das razões de decidir dos acórdãos do Supremo. Partindo da premissa de que muitos acórdãos são construídos "nos termos do voto do relator", os autores indicam que os ministros aceitam os argumentos de seu voto como sendo as razões da corte, o que desmistificaria a ideia de motivações dispersas como característica frequente dos julgamentos do tribunal. Em resposta, Virgílio Afonso da Silva (2016) questiona a importância, dada pelos autores, à expressão "nos termos do voto do relator”, que seria usada, grande parte das vezes, mais por força do hábito do que para realmente sinalizar a racionalidade de uma decisão coletiva. Esta constatação seria mais facilmente verificável nos casos relevantes, em que quase todos os ministros redigem votos: "Na ADI 3510, em mais de 500 páginas, há 11 votos articulados, votos vencidos nas mais variadas extensões e votos concorrentes com argumentos os mais diversos. Seria uma simplificação grosseira de todo o processo decisório imaginar que, apenas porque a expressão 'nos termos do voto do relator' foi utilizada, então as razões de decidir são somente aquelas expostas apenas naquele voto” (2016, p.661). 
Conrado Hübner Mendes (2012) buscou delinear o que seria uma corte deliberativa ideal, dividindo o processo decisório em três partes: pré-decisional, decisional e pós-decisional. O pré-decisional teria início com a existência de um lítigio concreto, sendo, nesta fase, produzidos os atos por meio dos quais as partes interagem com a corte. A fase decisional corresponderia ao momento em que os juízes interagem entre si em busca de uma decisão, enquanto a pós-decisional diria respeito à redação da decisão colegiada, bem como a toda sorte de debates que ocorrem na esfera pública em reação ao julgamento.

Nesse passo, ainda segundo o autor, uma boa interação colegiada não seria um duelo verbal, que é conduzido sob espírito de competição:

O parâmetro da interação colegiada requer que juízes escutem e incorporem as razões dos seus pares, seja para aderir ou para dissentir. Não são obrigados a esconder ou suprimir desacordos, mas comprometidos com uma argumentação franca em busca da melhor resposta. (...) Quando o acordo substantivo se mostra impossível, os predicados formais do Estado de Direito - tais como a certeza, a previsibilidade e a segurança jurídica - podem ser razões de segunda ordem a estimular concessões mútuas (2012, p.62/63).

Por sua vez, uma decisão escrita deliberativa deveria refletir o esforço de comunicar, de maneira palatável, o resultado do julgamento:

\begin{abstract}
Uma decisão deliberativa, portanto, não é um anúncio cifrado e convoluto da resposta supostamente correta, alcançada somente por aqueles que dominam os arcanos do Direito. Tampouco é uma afirmação apodítica, em virtude dos superpoderes interpretativos que a corte supostamente teria, do que a Constituição significa. É, em vez disso, o produto de um esforço sincero de lidar com todos os pontos de vista da maneira mais rigorosa e empática possível (2012, p.64).
\end{abstract}

Além disso, a redação do julgado teria o ônus de transformar o processo de argumentação interpessoal em um discurso concatenado e inteligível, produzindo uma decisão supraindividual. Caberia a ela equilibrar a necessidade de criar uma identidade institucional e o dever de respeitar as opiniões dissidentes, sendo sua função, portanto, quase tão fundamental quanto seu próprio conteúdo.

A forma de redação do acórdão é relevante também porque, conforme observado por Eduardo Mendonça (2008), é através das razões nele expostas que o tribunal se abre, de maneira especial, à crítica pública. Logo, para que o dever 
de fundamentação reforçada funcione, verdadeiramente, como mecanismo de exposição privilegiada da decisão ao crivo público, é preciso que esta fundamentação esteja acessível e clara aos jurisdicionados.

Tendo em vista estes nortes, será que o processo de deliberação do Supremo se aproxima de realizar o potencial que se espera da jurisdição constitucional? Será que atende aos critérios necessários para ser caracterizado como uma instância reflexiva e veiculadora da razão pública?

Com relação à fase decisional, de acordo com a classificação acima descrita, Virgílio Afonso da Silva (2013, p.578) avalia o Supremo Tribunal Federal como uma corte extremamente não cooperativa e individualista. A ausência de cooperação poderia ser explicada pelo fato de os ministros redigirem seus votos antecipadamente sem saber a posição do relator. O individualismo se manifestaria quando os ministros insistem em publicar seus votos mesmo quando eles são no mesmo sentido daquele proferido pelo relator ou quando estão de acordo com o primeiro voto dissidente.

O autor levanta algumas hipóteses para justificar este individualismo, já que, mesmo em uma corte não cooperativa, os julgadores poderiam optar por simplesmente aderir ao voto vencedor sem ler os, muitas vezes longos, votos individuais. Uma possibilidade se baseia na ideia da relação dos ministros com a audiência, caso em que a leitura dos votos não teria como alvo os colegas da corte, mas seria instrumentalizada para alcançar o público externo ${ }^{98}$. No Brasil, este problema seria potencializado diante do televisionamento, ao vivo, das sessões de julgamento. Este tipo de publicidade, apesar de muitas vezes festejada em nome da transparência, poderia representar prejuízo para o processo deliberativo. Isso porque, ao ler seu voto na frente das câmeras, o ministro estabeleceria um compromisso público com determinada posição, diminuindo sua propensão de ceder diante de contra-argumentos. Além disso, a publicidade extrema inibiria a utilização de métodos de "ensaio e erro" na deliberação, o que cercearia o

\footnotetext{
${ }^{98}$ Para ilustrar este tipo de situação, vale citar a justificativa que o ministro Luiz Fux apresentou para, mesmo acompanhando integralmente o relator, ler seu extenso voto no julgamento do $26^{\circ}$ Agravo Regimental da Ação Penal nº470: "Tencionava eu, de início, fazer talvez um resumo do voto, mas, tendo em vista a envergadura intelectual do que aqui, até então, se esclareceu e se votou, sinto-me no dever de, na qualidade de membro integrante que participou de cinquenta sessões desse julgamento, me colocar à altura daquilo que foi expendido aqui e que precisa, de alguma sorte, encontrar um debate típico de um colegiado que soma as suas manifestações divergentes" (p.104).
} 
potencial criativo do tribunal. Confidencialmente, juízes se sentiriam mais à vontade de expor argumentos sobre os quais não possuem certeza da aceitabilidade, por outro lado, quando filmados, apenas apresentariam razões sobre as quais se sintam seguros e aquelas que estariam dispostos a defender mesmo diante da objeção dos demais (SILVA, 2013, p.581). Indagados sobre o funcionamento da TV Justiça no âmbito do projeto História Oral do Supremo, Carlos Velloso (2015), Eros Grau (2016), Francisco Resek (2016), Nelson Jobim (2016) e Cezar Pelluso (2015) concordam que os votos passaram a ser mais extensos e que a exposição tornou mais difícil as mudanças de posição. Na mesma linha, o ministro Luís Roberto Barroso:

Quanto à TV Justiça, eu acho que ela traz algumas consequências negativas. Primeiro, a exposição tira um pouco da espontaneidade e, segundo lugar, e há estatística sobre isso, há uma pesquisa empírica, os votos ficam maiores. Em terceiro lugar, ela dificulta um pouco o processo de deliberação porque, numa conversa informal, você pode ir, vir, reajustar. Ao vivo e em cores para todo o Brasil, esse processo circular, que num debate informal pode acontecer, de avanços e recuos, concessões, é mais difícil, embora não seja impossível. Mas eu acho que dificulta ligeiramente algum tipo de acomodação que possa traduzir consensos, o que talvez seja bom. (2016, p.123)

Conrado Hübner Mendes acrescenta que elementos culturais podem contribuir para este caráter individualista do Supremo:

As sessões de julgamento do STF sugerem certa inclinação ao que Hirschman chamou, em outro contexto, de "superprodução de opiniões teimosas". Para este autor o remédio contra tal tipo de costume individual ou institucional seria incutir, ao lado do "deleite de ganhar um debate", o "prazer de ser um bom ouvinte". O individualismo predominante no STF, porém, não tem muito a ver com "ganhar o debate". Ganhar ou perder, no ambiente do Tribunal, importam menos do que marcar publicamente a opinião individual, especialmente, nos casos de maior saliência pública. O STF cultiva e premia a emissão de "opiniões fortes”, que resistem, por princípio, ao contra-argumento para evitar qualquer sinal de fraqueza moral e intelectual ${ }^{99}$. O STF seria, nos termos de uma recorrente metáfora musical invocada para ilustrar empreitadas cooperativas, não uma "orquestra", onde o todo é maior que a soma das partes, mas um "tribunal de solistas”, no qual o virtuosismo individual prevalece - em vez de se subordinar sobre o ideal de um concerto. (2012, p.72)

\footnotetext{
${ }^{99} \mathrm{O}$ ex-ministro Ayres Britto parece concordar com esta avaliação, já que, em entrevista à Revista Piauí, afirmou em relação ao STF: "O que eu vejo aqui é certa competição surda, enrustida, latente, uma competitividade não assumida, que não tem sentido e é absurda. O Supremo não está a salvo de práticas reveladoras de uma certa pequenez de alma. Aqui e ali, um ou outro ministro precisa do confronto pessoal e da disputa de espaço para demarcar seu campo. Isso é meio mórbido.” (Disponível em: <http://piaui.folha.uol.com.br/materia/o-supremo-quousque-tandem/>. Acesso em: 19 set. 2016)
} 
Estas dificuldades se refletem na fase pós-decisional em que os ministros deveriam apresentar um acórdão que refletisse razões colegiadas, mas, muitas vezes, o resultado final é uma sobreposição de votos individuais, construídos a partir de premissas diferentes e independentes. A redação final, portanto, não atende à ideia de produção de um documento supraindividual, que contemple uma posição institucional e respeite as opiniões dissidentes. Muitas vezes, o acórdão não fornece elementos suficientes para a compreensão das razões dos votos que seguem o condutor. Mesmo em relação àqueles que expressam fundamentação própria, a extensão da concordância só poderia ser conhecida se houvesse manifestação específica sobre todos os pontos abordados pelo relator, o que nem sempre acontece. Fábio Carvalho Leite e Marcelo Santini Brando (2016) resumem de forma precisa os problemas daí derivados:

\begin{abstract}
Abstraindo-se a polêmica metaética entre cognitivistas e não-cognitivistas que está por trás da tese da "resposta certa” nos casos difíceis moralmente carregados (Miller 2003), é difícil sustentar que o STF "acerta" ou "erra" quando não é possível determinar em torno de que os ministros acordaram. O simples fato de terem que apresentar as justificações racionais para suas decisões não reduz as chances de erro, pelo menos se encararmos a prática da Corte. Não raro os ministros apresentam a seus pares longuíssimos votos que elevam o grau de abstração das discussões constitucionais, entrelaçando-as com conceitos como dignidade humana, liberdade, igualdade e justiça social. Todavia, cada ministro decide isoladamente sem a preocupação de relacionar seu voto com o do relator ou de seu antecessor na própria sessão de julgamento, bem como com qualquer fundamento contido em outro pronunciamento (Klafke 2010). Por vezes, quando tais referências são feitas, elas são "superficiais, dispensáveis ou meramente elogiosas” (Klafke 2010, 119). Como observou José Rodrigo Rodriguez, a Corte não se reúne para redigir sua decisão de maneira ordenada em um texto coerente acompanhado dos eventuais votos dissidentes. Tem-se o que ele chamada de justiça opinativa (Rodriguez 2013, 63 e 79). Ainda que a Corte "acerte” no resultado e declare a inconstitucionalidade de uma lei ou ato normativo suponha-se que a comunidade de operadores do direito esteja de acordo que este é o resultado correto -, não seremos capazes de extrair a ratio decidendi do acórdão.
\end{abstract}

Neste cenário, a própria formação da jurisprudência é comprometida ${ }^{100}$, conforme observado por Sundfeld e Pinto:

${ }^{100}$ No mesmo sentido, Conrado Hübner Mendes (2012) observa que: "Do ponto de vista formal, tal patologia restringe significativamente a capacidade do STF de produzir precedentes a partir dos quais se construa autêntica jurisprudência constitucional. Se é verdade que o significado de uma Constituição está menos em seu texto que na jurisprudência que a interpreta e aplica, o significado da Constituição brasileira permanece fragmentado e instável. Continua refém das idiossincrasias 
Apesar de colegiadas, as decisões tomadas pelo Plenário e por suas duas Turmas tendem a refletir a individualidade do ministro que se destacou na determinação do resultado e da sua fundamentação, o que acaba por desvalorizar o sentido coletivo de jurisprudência. Na quase totalidade dos casos há um papel proeminente do ministro condutor (isto é, o relator ou aquele que assumiu a posição de proferir os fundamentos centrais da decisão, designado como redator para acórdão). Mesmo sendo formadas em órgãos colegiados, as decisões não se tornam propriamente coletivas (2012, p.25).

Estas características do processo decisório do STF têm influência direta na forma como avaliamos a atuação da corte na cena política. De um lado, temos o imaginário de um locus de deliberação ideal, em que os ministros estariam abertos a serem convencidos pelas razões apresentadas e constrangidos a responder a todos os argumentos expostos. De outro, temos uma corte que, em sua atuação, se revela extremamente individualista, cujos membros parecem estar mais preocupados em expor seus pontos de vista do que a chegar a um consenso. Para além da oposição entre teoria e prática, entre o ideal e o real, temos que pensar nos custos de lidar com um ator político pouco afeito a uma deliberação franca e que não zela por uma construção jurisprudencial sólida.

Estes custos são de várias ordens. A primeira delas pode ser relacionada, mais uma vez, ao descompasso entre o grande poder que os membros do tribunal possuem e os mecanismos de controle. Em um quadro de pouco zelo com a construção jurisprudencial, a confusão gerada pela não identificação de uma ratio decidendi nos acórdãos e pela inexistência de um estado de síntese da jurisprudência pode ser instrumentalizada para endossar posições pessoais dos ministros independentemente de possuírem lastro real em uma opinião da corte. Algumas decisões podem aparentar estarem de acordo com um precedente, mas, na realidade, não refletirem um diálogo franco com os julgados anteriores. Esta situação é mais fácil de ser visualizada em decisões monocráticas, em que o ministro tem mais liberdade na redação final do julgado, mas também pode ocorrer em decisões colegiadas.

Foi o que parece ter acontecido a partir do julgamento da ADPF 130 que decidiu pela não-recepção da Lei de Imprensa (Lei nº5.250/1967) pela

de cada ministro do STF. Quando decisões se resumem, em última análise, a nada mais que a soma das partes, precedentes não são firmados e nenhuma jurisprudência finca raízes no ordenamento constitucional brasileiro.” (p.72) 
Constituição de 1988. Este julgamento representou um marco na jurisprudência do tribunal não apenas por ter sido uma manifestação de controle abstrato de constitucionalidade, que possui efeito vinculante, mas também porque, a partir daí, inúmeras reclamações têm sido admitidas e liminares deferidas com o propósito de garantir a autoridade das razões de fundo daquela decisão.

Captando a peculiaridade da influência do citado julgamento nas decisões posteriores da corte, o ministro Luís Roberto Barroso, em voto proferido na Medida Cautelar na Reclamação n ${ }^{0}$ 22.328/RJ, declarou:

Idealmente, as decisões proferidas pelo Supremo Tribunal Federal em controle abstrato de constitucionalidade devem ter eficácia vinculante não apenas quanto à parte dispositiva do julgado, mas também quanto aos próprios fundamentos que embasaram a decisão. Em outras palavras: juízes e tribunais devem acatamento não apenas à conclusão do acórdão, mas igualmente às razões de decidir nele enunciadas. É o que se tem denominado de transcendência dos motivos determinantes. Esse efeito vinculante mais amplo das decisões proferidas pelo STF integra a lógica e a racionalidade da jurisdição constitucional, que envolve a fixação de teses jurídicas a serem observadas pelas instâncias judiciais. Por essa razão, tenho defendido que todo julgamento seja concluído com a explicitação do entendimento em que se fundou a decisão.

8. Todavia, a jurisprudência do Supremo Tribunal Federal em matéria de reclamação tem sido parcimoniosa no reconhecimento de transcendência aos motivos determinantes de suas decisões. Como regra geral, a eficácia tem sido limitada à parte dispositiva da decisão; isto é, à declaração de constitucionalidade ou inconstitucionalidade de determinada norma infraconstitucional. Trata-se de uma jurisprudência defensiva, destinada a conter a multiplicação de reclamações, em número que ultrapassaria a capacidade física de julgamento dos ministros.

9. Essa linha restritiva, no entanto, tem sido excepcionada justamente quando estejam em questão temas afetos à liberdade de expressão ou à liberdade de imprensa. Nesses casos, inúmeras decisões do STF têm admitido reclamações e deferido liminares com o propósito de assegurar o conteúdo conferido pela Corte a tais direitos, mesmo quando a decisão reclamada não se baseia no mesmo ato declarado inconstitucional em sede concentrada[1].

10. Não é difícil explicar a razão. A liberdade de expressão ainda não se tornou uma ideia suficientemente enraizada na cultura do Poder Judiciário de uma maneira geral. Não sem sobressalto, assiste-se à rotineira providência de juízes e tribunais no sentido de proibirem ou suspenderem a divulgação de notícias e opiniões, num "ativismo antiliberal” [2] que precisa ser contido. Por considerar que uma vez mais se está diante de situação de sacrifício ilegítimo da liberdade de expressão, conheço da reclamação. ${ }^{101}$

${ }^{101}$ Vale mencionar que existem algumas posições discrepantes no tribunal, como a do ministro Dias Toffoli, exposta na Reclamação $\mathrm{n}^{\circ}$ 18776, que impugnava decisão da Justiça Eleitoral determinando a retirada de um vídeo do canal Porta dos Fundos no Youtube. O ministro entendeu que não havia identidade entre o debate travado na reclamação "e o entendimento vinculante apto a instaurar o exercício da jurisdição, em sede reclamatória, pelo Supremo Tribunal Federal. (Disponível em: <http://www.stf.jus.br/portal/cms/verNoticiaDetalhe.asp?idConteudo=276832>. Acesso em: 10 fev. 2017.) 
Na $A D P F n^{0} 130$, o julgamento pela não recepção integral foi por maioria de votos, vencidos o ministro Joaquim Barbosa e a ministra Ellen Gracie que julgavam improcedente quanto aos artigos $1^{\circ}, \S 1^{0} ; 2^{\circ}$, caput; 14; 16, inciso I; 20; 21 e 22, o ministro Gilmar Mendes que julgava improcedente quanto aos artigos 29 a 26 e o ministro Marco Aurélio que julgava a demanda improcedente integralmente. O acórdão possui 334 páginas, sendo que apenas o ministro Eros Grau não publicou seu voto.

Os ministros Celso de Mello, Cezar Peluzo, Menezes Direito, Ricardo Lewandowski e Carmen Lúcia, apesar de acompanharem o relator Carlos Britto, fizeram questão de ler seus longos votos, sendo que cada um deles apresentou sua concepção sobre a liberdade de imprensa, abordando o tema a partir de uma perspectiva histórica, de direito comparado ou a partir de outros pontos que entenderam relevantes.

Lida a transcrição do julgamento, a conclusão a que se chega é de que os temas verdadeiramente debatidos entre os ministros do STF foram a possibilidade de intervenção estatal pela via legislativa na liberdade de imprensa e a necessidade regulamentação do direito de resposta para sua efetiva aplicação. A questão de como solucionar conflitos entre direitos fundamentais pelo Poder Judiciário não foi objeto de grandes discussões entre eles. Ressalvando o ministro Celso de Mello, que manifestou sua discordância com relação ao sistema de “calibração cronológica” proposto pelo relator, adotando o critério da ponderação, e o ministro Ricardo Lewandowski, que mencionou a proporcionalidade, os demais membros da corte não teceram comentários minuciosos sobre o tema. A própria calibração não foi abordada por nenhum outro ministro.

É que, além das dificuldades na deliberação já mencionadas, a forma com que os ministros costumam construir seus argumentos contribui para que soluções mais concretas não sejam de fato discutidas. Como apontam Sundfeld e Pinto:

A própria maneira pela qual o STF justifica suas decisões, cada vez mais assemelhada à construção de "teorias" sobre os problemas abstratos envolvendo sua própria legitimidade e capacidade de atuação e sobre o plano geral dos temas constitucionais envolvidos, não é suficiente para cumprir os ônus da competência e do regulador. E isto porque tais justificativas "teóricas" praticadas pelos ministros permanecem no plano das generalidades e abstrações, sem investigar as dificuldades concretas trazidas pelas demandas e situações perante as quais irá 
decidir. São razões insuficientes para a formulação consistente de conclusões concretas em contextos de divergências fundamentadas sobre o sentido das normas constitucionais, porque não alcançam o cerne do problema levado à apreciação do Tribunal. Ao mesmo tempo, são razões escoradas em ideias de certa forma incontestáveis em si mesmas, sobre as quais não há discordâncias plausíveis (2012, p.45).

Logo, é curioso que, nos repetidos casos em que juízes e tribunais condenam um jornalista a indenizar por suposta ofensa a direitos da personalidade, as reclamações ajuizadas sejam admitidas em razão da contrariedade ao que ficou decidido na ADPF $\mathrm{n}^{\circ} 130$. Mais do que isto, ao analisar algumas destas reclamações ${ }^{102}$, o que se percebe é que, para ponderar entre os direitos envolvidos, os ministros se baseiam em trechos retirados de seus próprios votos, que não necessariamente foram endossados pelo colegiado, ou até em critérios desenvolvidos fora daquele julgamento, como foi o caso do ministro Barroso na decisão da Medida Cautelar na Reclamação $n^{0} 18.638^{103}$. Não é questão de afirmar que tais parâmetros utilizados para a solução de processos subjetivos contrariam o acórdão da APDF $\mathrm{n}^{\circ}$ 130, mas de que, no referido julgamento, a única pista realmente objetiva para a harmonização dos direitos em jogo foi a calibração temporal proposta pelo relator e incluída na ementa do julgado sem que houvesse um debate amplo do colegiado sobre sua adoção.

Percebe-se, assim, que, apesar de a ADPF $\mathrm{n}^{\circ} 130$ ser utilizada como reforço argumentativo, os ministros julgam os casos concretos que envolvem liberdade de expressão conforme seu próprio entendimento. Tendo em vista a grande extensão do acórdão, dificilmente a crítica pública poderia alcançar eventuais inconsistências nas citações realizadas. Um caso interessante aconteceu no julgamento da Rcl. 18.735, em que o ministro Gilmar Mendes foi chamado a se manifestar sobre direito de resposta concedido, contra a revista Veja e em favor do Partido dos Trabalhadores, pelo Tribunal Superior Eleitoral. Às vésperas da eleição presidencial de 2014, em decisão liminar, o ministro fixou o seguinte posicionamento:

\footnotetext{
${ }^{102}$ Como exemplos: Rcl. 18.836, Rcl. 18.290, Rcl. 15.243, Rcl. 18.638, Rcl. 19.567, Rcl. 20.989, Rcl.16.074, Rcl.16.434, Rcl.18.186, Rcl.18.566, Rcl.18.746, Rcl.16.434, Rcl.18.735, Rcl. 21.504, Rcl. 19.567, Rcl.11.292 e Rcl.16.329.

${ }^{103}$ Neste julgado, o ministro cita 8 critérios ou elementos, elaborados por ele e publicados no livro Temas de direito Constitucional, tomo III, a serem considerados na ponderação entre a liberdade de expressão e os direitos da personalidade.
} 
Finalmente, nessa mesma linha, ressaltei em meu voto que o direito de resposta, também previsto na maioria dos países democráticos que garantem a liberdade de imprensa, é assegurado "a todo aquele (pessoa física ou jurídica, pública ou privada) que sofra agravo proveniente de informação (notícia) errônea ou inverídica veiculada por meio da imprensa. Trata-se de uma garantia de resposta, retificação, correção, esclarecimento, contestação ou refutação da notícia inverídica ou errônea, de forma proporcional ao agravo sofrido, no mesmo meio de comunicação”.

Importante trazer à tona essas colocações feitas durante o julgamento da ADPF 130, para que fique claro que o direito de resposta admitido constitucionalmente é aquele decorrente de informação falsa, errônea. Significa dizer que é preciso haver comprovação nos autos de que a informação veiculada na mídia é inverídica. Parece-me que o rito sumário comumente adotado pelas regras de regência do processo judicial eleitoral dificilmente se presta à produção de provas desse tipo.

\section{(...)}

Nota-se, assim, que é simplesmente impossível afirmar, desde já e em processo de cognição sumária, típico da celeridade requerida da Justiça Eleitoral, que os fatos descritos pela reportagem impugnada no TSE sejam inverídicos, falsos.

Entretanto, não foi este o entendimento sedimentado pelos ministros no debate sobre o direito de resposta na ADPF 130 - um dos poucos temas efetivamente discutidos por eles. Durante este julgamento, o próprio ministro Gilmar Mendes havia se mostrado preocupado em garantir que este direito alcançasse também os casos de ofensa e não apenas os de fatos inverídicos. Por isso, propôs a manutenção do art.29 da Lei 5.250/67 com uma interpretação conforme a Constituição para que abrangesse o discurso ofensivo. Os demais ministros, adeptos à não recepção em bloco da lei, defenderam que, na ausência de norma, o juiz poderia aplicar o direito de acordo com as necessidades do caso concreto, o que seria mais benéfico para um eventual ofendido. Ressalte-se, ainda, que item 11 da ementa do acórdão da ADPF 130 determina que "o direito de resposta, que se manifesta como ação de replicar ou de retificar matéria publicada, é exercitável por parte daquele que se vê ofendido em sua honra objetiva, ou então subjetiva, conforme estampado no inciso V do art.5 da Constituição Federal.” Se a honra subjetiva poderia ser protegida pelo direito de resposta, não há nenhuma base para o entendimento esposado pelo ministro Gilmar Mendes na reclamação supracitada.

Vale mencionar que o caso acima descrito não passou pelo crivo do colegiado, já que, posteriormente, o relator reconheceu a perda superveniente do 
objeto da Reclamação em razão do encerramento do período eleitoral. Nota-se, portanto, que os mecanismos de controle frente a situações como esta são muito frágeis, já que, para a opinião pública, é quase impossível alcançar este nível de análise diante da forma de elaboração do acórdão e, para o próprio tribunal enquanto instituição, em razão dos mecanismos do seu funcionamento, é possível que a questão se encerre com uma decisão individual.

Hipóteses como esta levantam sérias dúvidas de que o Supremo possa, de fato, exercer o papel de representante argumentativo da sociedade ou de que ocupe o lugar da legitimação discursiva por excelência. $\mathrm{O}$ dever de fundamentação reforçada não parece garantir uma abertura privilegiada à crítica pública. Além disso, a racionalidade significa, em certo sentido, que as decisões judiciais precisam ser reconduzidas a algum elemento do sistema jurídico, ônus que o Judiciário carrega e o Legislativo não. Se o elemento do sistema jurídico em questão, a jurisprudência, pode ser manipulado ao sabor das conveniências, não sobra argumento para sustentar a superioridade de uma instância deliberativa sobre a outra.

Como já mencionado anteriormente, o processo deliberativo e os fundamentos apresentados como razões de decidir são dois elementos relacionados que podem definir a capacidade argumentativa da corte. As falhas no processo deliberativo geram efeitos substantivos, atrapalhando a corte de alcançar as melhores soluções para os casos concretos. Quando os mecanismos de deliberação não auxiliam a construção de precedentes e o diálogo franco com a jurisprudência ${ }^{104}$, discussões que poderiam ser resolvidas através do recurso a estes elementos tornam-se complexas e dão margem a uma maior subjetividade na fundamentação da decisão.

Foi o que ocorreu no julgamento do vigésimo sexto Agravo Regimental interposto no bojo da Ação Penal n ${ }^{\circ} 470$ - conhecida na mídia como processo do

\footnotetext{
${ }^{104}$ Sobre os conceitos de jurisprudência e de precedente, Rafael Lorenzo Koatz (2015) esclarece que não se tratam de sinônimos nem se destinam aos mesmos fins, apesar de a doutrina brasileira não os distinguir: "Jurisprudência está relacionada à ideia de repetição; à afirmação de um conceito, de uma tese jurídica; à revelação do sentido da lei. A ideia de jurisprudência está intimamente atrelada à prudência, reflexão. Produzir jurisprudência é, antes de mais nada, um exercício de reflexão e de análise; de meditação e de ponderação; e de reiteração. A ideia de precedente, por outro lado, é diversa em muitos aspectos. Precedente é o que vem antes; a força de um precedente não está na sua reiteração; está no seu respeito e na sua utilização com diretriz de casos semelhantes. O precedente tem um papel pedagógico e orientador inegável.”(p.49-50)
} 
mensalão - que discutia o cabimento ou não de embargos infringentes em ação penal originária em curso no STF. Note-se que o próprio tema objeto de discussão - cabimento ou não de um recurso previsto no Regimento Interno do STF (RI/STF) - já sugere que a solução do caso se daria com base no entendimento construído previamente pelo tribunal ao longo dos anos, fosse para confirmá-lo fosse para superá-lo. Nesta última hipótese, o ônus argumentativo seria alto, uma vez que o caso tinha forte apelo político e os réus, bem como uma parte da opinião pública, defendiam que se estava diante de um julgamento de exceção.

A questão envolvia a vigência do art.333, I, do RI/STF ${ }^{105}$, regra que previa os embargos infringentes em ações penais originárias. Com o advento da Lei n8.038/90, que instituiu normas procedimentais a serem aplicadas no Supremo Tribunal Federal e no Superior Tribunal de Justiça e tratou de forma específica deste tipo de ação, surgiu a tese de que, por não haver menção expressa a este recurso na lei, o referido artigo do regimento interno teria sido revogado tacitamente $^{106}$. Diante desta questão e considerando o forte clamor público que o caso envolvia, cabia a pergunta: e antes da AP $n^{\circ} 470$, qual era o entendimento do tribunal sobre a vigência deste artigo?

Pois bem. O relator, ministro Joaquim Barbosa, que se posicionou contra a admissibilidade do recurso, apresentou, dentre outros argumentos, precedente do próprio STF, relatado pelo ministro Celso de Mello, que considerava descabidos embargos infringentes em ação penal originária perante Tribunal Regional Federal. De acordo com este julgado, embargos infringentes somente são cabíveis em caso de apelação ou de recurso em sentido estrito, nos termos do art. 609, parágrafo único, do Código de Processo Penal.

Já o ministro Luís Roberto Barroso, que entendia pelo cabimento do recurso, argumentou que existiriam inúmeros pronunciamentos no sentido de que

\footnotetext{
105 Art. 333. Cabem embargos infringentes à decisão não unânime do Plenário ou da Turma:

I - que julgar procedente a ação penal;

II - que julgar improcedente a revisão criminal;

III - que julgar a ação rescisória;

IV - que julgar a representação de inconstitucionalidade;

V - que, em recurso criminal ordinário, for desfavorável ao acusado;

Parágrafo único ${ }^{1}$. O cabimento dos embargos, em decisão do Plenário, depende da existência, no mínimo, de quatro votos divergentes, salvo nos casos de julgamento criminal em sessão secreta.

${ }^{106}$ Posição defendida por Lênio Streck no artigo "Não cabem embargos infringentes no Supremo”. Disponível em: <http://www.conjur.com.br/2012-ago-13/mensalao-nao-cabem-embargosinfringentes-supremo>. Acesso em: 14 set. 2016.
} 
o art.333 do RI/STF continuava em vigor. Alguns deles foram transcritos em seu

voto:

Plenário, Ementa: "Não se mostram admissíveis embargos infringentes contra decisão majoritária do Plenário (ou das Turmas) do Supremo Tribunal Federal, se tal decisão vem a ser proferida em causa diversa daquelas enunciadas, taxativamente, em rol exaustivo (numerus clausus), no art. 333 do RISTF. Precedentes" ${ }^{107}$

Plenário, Ementa: “(...) 1. Não cabem embargos infringentes no caso presente, tendo em vista que não houve divergência de quatro votos em qualquer questão decidida no acórdão embargado. Artigo 333, parágrafo único, do Regimento Interno do Supremo Tribunal Federal. Tratando-se de embargos declaratórios, não se admite modificação meritória do entendimento já exarado. Precedentes. $(\ldots), 108$

Plenário, Ementa: "Embargos infringentes em ação direta de inconstitucionalidade. Tendo sido objeto de recepção os dispositivos do Regimento Interno da Corte que, por causa da competência legislativa que lhe fora outorgada pela ordem constitucional anterior, dizem respeito a matéria processual, eles persistem com força de lei até serem revogados por legislação posterior, o que não ocorreu pela circunstância de a Lei $n^{0}$ 8.038, de 28.05.90, que não é exauriente sobre as ações e os recursos no âmbito deste Supremo Tribunal Federal, ter sido omissa quanto a tais embargos. - Nesse sentido, aliás, já decidiu esta corte, quando de julgamento dos embargos infringentes na ação direta de inconstitucionalidade $\mathrm{n}^{\circ}$ 29. (...) Embargos infringentes conhecidos, mas rejeitados." ${ }^{109}$

Primeira Turma, Ementa: "EMBARGOS INFRINGENTES NO AGRAVO REGIMENTAL NO AGRAVO DE INSTRUMENTO. DECISÃO QUESTIONADA QUE NÃO SE INSERE NAS HIPÓTESES DO ART. 333 DO RISTF. REITERADA JURISPRUDÊNCIA DESTA CORTE. EMBARGOS NÃO CONHECIDOS. I - Entre as hipóteses de cabimento deste recurso, elencadas no art. 333 do Regimento Interno do STF, não se inserem as decisões não unânimes proferidas pelo Plenário ou pela Turma, que negam provimento a agravos regimentais interpostos em agravos de instrumento criminais. II Embargos infringentes não conhecidos.”110

Primeira Turma, Ementa: "Embargos infringentes criminais: descabimento da decisão condenatória não unânime, nos processos de competência originaria dos Tribunais, salvo no Supremo Tribunal Federal: inexistência, no ordenamento brasileiro, da garantia do duplo grau de jurisdição, a qual, de resto, não satisfaria a admissão de embargos infringentes, que não são recurso ordinário: consequente legitimação da imediata prisão do condenado, independentemente de sua

\footnotetext{
${ }^{107}$ STF, AgRg no AgRg no HC 88.247, Rel. Min. Celso de Mello, decisão de 17.09.2009. No mesmo sentido, com redação quase idêntica, v. Embargos no RE 172.004 AgRg, Rel. Min. Celso de Mello, decisão de 27.05.1998.

${ }^{108}$ STF, ED na AO 1.046/RR, Rel. Min. Joaquim Barbosa, decisão de 28.11.2007.

${ }^{109}$ STF, EI na ADI 171/MG, Plenário, Rel. Min. Moreira Alves, decisão de 14.09.1994. Observação: "Por votação unânime o Tribunal conheceu dos embargos e por maioria de votos os rejeitou, vencidos os Ministros Francisco Rezek, Marco Aurélio, Carlos Velloso, Celso de Mello e Néri da Silveira, que acolhiam os embargos".

${ }^{110}$ STF, EI no AgRg no AI 828.792/SP, Rel. Min. Ricardo Lewandowski, Primeira Turma, decisão unânime de 28.06.2011.
} 
necessidade cautelar e não obstante o cabimento em tese de recursos extraordinários, sem efeito suspensivo (ressalva no ponto do relator)”. ${ }^{111}$

O ministro Barroso citou também decisões monocráticas e votos elaborados por ministros que participariam do julgamento do Agravo Regimental da AP 470:

Voto do Ministro Celso de Mello: "É certo que as decisões plenárias proferidas pelo Supremo Tribunal Federal podem ser questionadas em sede recursal, mediante interposição de embargos infringentes para o próprio Plenário desta Corte na forma e nos casos previstos no art. 333 do RISTF" ${ }^{112}$

Decisão monocrática do Min. Celso de Mello: “Impende acentuar, bem por isso, que a norma inscrita no art. 333, parágrafo único, do RISTF, hoje com força e eficácia de lei, foi editada, validamente, pelo Supremo Tribunal Federal, com apoio em regra de competência que permitia, a esta Corte, formular, em sede meramente regimental, preceitos de conteúdo materialmente legislativo, como aqueles que disciplinavam o processo e o julgamento dos feitos de sua competência originária ou recursal.

Daí o fato, juridicamente relevante, de que a cláusula regimental em questão foi recebida pelo vigente ordenamento constitucional, achando-se, por isso mesmo, impregnada da plena validade e eficácia jurídicas, o que legitima, em conseqüência, a sua invocação". ${ }^{113}$

Decisão monocrática do Ministro Luiz Fux: “A respeito do tema, está previsto no parágrafo único do artigo 609 do Código de Processo Penal o cabimento de embargos infringentes e de nulidade, quando em apelação ou recurso em sentido estrito, por maioria, for proferido julgamento desfavorável ao acusado. No âmbito do Supremo, a matéria está disciplinada no regimento interno, admitindo-se os infringentes como via adequada para impugnar decisão condenatória, não unânime, proferida em ação penal, quando julgada improcedente a revisão criminal e, ainda, em face do desprovimento de recurso criminal ordinário (RISTF, artigo 333, incisos I a III e V).

In casu, a interposição de embargos infringentes contra acórdão mediante o qual, por maioria, a Turma indeferiu o pedido de habeas corpus não encontra amparo legal, devendo ser observado o princípio da taxatividade dos recursos”"114

Decisão monocrática da Ministra Cármen Lúcia: "Neste Supremo Tribunal Federal, cabem embargos infringentes, tão-somente, contra decisão não unânime do Plenário ou da Turma a) que julgar procedente a ação penal; b) que julgar improcedente a revisão criminal; c) que julgar a ação rescisória; d) que julgar a representação de inconstitucionalidade; e e) que, em recurso criminal ordinário, for desfavorável ao acusado de crime político (art. 333 do Regimento Interno do Supremo Tribunal Federal); a dizer, não há previsão legal ou regimental que autorize a oposição de embargos infringentes contra decisão majoritária,

${ }^{111}$ STF, HC 71.124/RJ, Rel. Min. Sepúlveda Pertence, Primeira Turma, decisão unânime de 28.06.1994.

${ }^{112}$ EI no RE 172.004 AgRg, Rel. Min. Celso de Mello, decisão de 27.05.1998, trecho do voto proferido pelo relator.

${ }_{113}^{11}$ STF, EI na AP 409/CE, Rel. Min. Celso de Mello, decisão monocrática de 16.04.2012.

${ }^{114}$ STF, ED no HC 104.075/SE, Rel. Min. Luiz Fux, decisão monocrática de 29.02.2012. 
desfavorável ao paciente, em habeas corpus ou em recurso ordinário em habeas corpus." 115

Prosseguindo em seu voto, Barroso negou que o julgado citado pelo relator pudesse servir de base para a resolução do impasse dos autos, uma vez que versava sobre embargos infringentes perante Tribunais inferiores e a controvérsia dizia respeito justamente ao cabimento deste recurso com base no Regimento Interno do STF, obviamente não aplicável àqueles tribunais. O ministro ainda discutiu se as decisões por ele apresentadas teriam o condão de formar jurisprudência, tendo em vista que as menções ao art.333, do RI/STF não teriam integrado o dispositivo de um julgado específico:

Nessas condições, é a jurisprudência atual da Corte que se mostra incompatível com a tese que o art. 333 teria sido objeto de revogação em 1990. Ainda que se quisesse afirmar que as menções não teriam integrado o dispositivo de um julgado específico, a reiteração de tantas referências à vigência do referido dispositivo não pode ser simplesmente ignorada pela Corte. Sobretudo quando se constata que não se tratou apenas de obiter dicta, e sim da própria razão de decidir expressa, prevalente em algumas dezenas de decisões monocráticas e acórdãos, inclusive do Plenário.

É certo que cada um dos Ministros, incluindo os que tenham produzido manifestação escrita individual, pode fazer a opção legítima de modificar seu pronunciamento anterior, como acontece eventualmente pela natural evolução de entendimentos. No entanto, com todas as vênias às opiniões em sentido contrário, entendo que elementos constitucionais como os princípios do Estado de Direito, da segurança jurídica, do devido processo legal e da própria legalidade impedem o Tribunal de ignorar dispositivo que sempre se considerou vigente a fim de abreviar o desfecho de processo penal determinado. Em outras palavras, pode-se revogar o dispositivo regimental - e há boas razões para que isso seja feito -, mas não se justifica que a Corte ignore seus próprios pronunciamentos recentes para, na reta final de um julgamento emblemático, sustentar que ele se encontra revogado desde 1990.

A transcrição destas decisões suscitou debate entre os ministros: Joaquim Barbosa e Marco Aurélio Mello insistiam que não houve a formação de precedente porque a menção não constava no dispositivo de nenhum acórdão:

O SENHOR MINISTRO JOAQUIM BARBOSA (PRESIDENTE E RELATOR) - Mas Vossa Excelência tem como verificar. Consta da ementa de algum acórdão?

O SENHOR MINISTRO MARCO AURÉLIO - E a situação concreta que apreciamos não estava em jogo. Então, não houve decisão a respeito.

115 STF, EI no RHC 97.473/DF, Rel. ${ }^{\text {a }}$ Min. ${ }^{\text {a }}$ Ministra Cármen Lúcia, decisão monocrática de 16.04.2010 
O SENHOR MINISTRO ROBERTO BARROSO - Exatamente. Eu refleti sobre essa questão, Presidente. E, verdadeiramente, as referências, no mais das vezes, foram feitas, sim, em obiter dicta ou na motivação da decisão, mas claramente, na construção do seu argumento, todos esses Ministros consideraram que o artigo 333 estava em vigor. Portanto, eu não estou afirmando que se formou coisa julgada, material que fosse, em relação à subsistência, o que eu estou afirmando é que todos esses Ministros que eu estou citando, e mais outros tantos que integram o Plenário, ao argumentarem sobre embargos infringentes, em outras situações, reconheceram, de maneira inequívoca, que eles continuavam vigentes.

O SENHOR MINISTRO MARCO AURÉLIO - Vossa Excelência admite que não há precedente sobre a matéria?

O SENHOR MINISTRO ROBERTO BARROSO - Eu admito que não há um dispositivo de acórdão específico sobre a matéria.

O SENHOR MINISTRO JOAQUIM BARBOSA (PRESIDENTE E RELATOR)

- Então, não há precedente, Ministro. O que há são frases esparsas.

O SENHOR MINISTRO MARCO AURÉLIO - Precedente pressupõe dispositivo, não fundamentação estranha ao que esteve em julgamento.

O SENHOR MINISTRO JOAQUIM BARBOSA (PRESIDENTE E RELATOR)

- Exatamente. O que há são frases esparsas encontráveis em votos. Precedente é exatamente isso que o Ministro Marco Aurélio acaba de dizer.

O SENHOR MINISTRO ROBERTO BARROSO - Eu entendo perfeitamente. O que eu estou afirmando é que o Ministro Cezar Peluso, aqui desta bancada, considerou que não estava revogado. E o Ministro Sepúlveda Pertence, aqui desta bancada, considerou que não estava revogado. (p.66)

Em seguida, o ministro Celso de Mello interveio para mencionar que:

Ainda que não haja precedente específico desta Corte em torno da subsistência dos embargos infringentes fundados no art. 333, $\mathrm{n}^{\circ} \mathrm{I}$, do RISTF, o fato relevante reside na circunstância de que diversos e eminentes Juízes do Supremo Tribunal Federal, quer em decisões monocráticas, quer em julgamentos colegiados, têm reconhecido a inocorrência da extinção dessa modalidade recursal no contexto da prática jurisdicional da Corte.

Diante disso, o ministro Joaquim Barbosa trouxe à baila o acórdão da ADI $\mathrm{n}^{\circ} 1591$, “este sim um precedente”, segundo ele, em que restou consignado que o art.26 da Lei n ${ }^{\circ}$ 9.868/99 implicou a abolição dos embargos infringentes previstos no art.333, RI/STF. O artigo da Lei nº.868/99 determina, expressamente, que a decisão que declara a constitucionalidade ou a inconstitucionalidade de lei ou ato normativo em ação direta ou em ação declaratória é irrecorrível, ressalvada a interposição de embargos declaratórios. Ao ouvir do ministro Barroso que a situação era diferente já que a revogação aí foi expressa, Joaquim Barbosa, visivelmente irritado, afirmou: 
Ou seja, casuísmo seria isso, a meu ver: para o efeito da ação direta, o artigo 333 do Regimento não mais subsiste, mas, para protelar um julgamento, levar um julgamento à eternidade, ele subsiste. Isso é uma grande contradição. Mas há mais, Ministro...

É que tanto o relator quanto o ministro Gilmar Mendes haviam utilizado o argumento da eternização do julgamento e do risco de descrédito do Judiciário para sustentar o não cabimento dos embargos:

Na verdade, admitir-se embargos infringentes no caso é, em última análise, apenas uma forma de eternizar o feito, o que seguramente conduzirá ao descrédito a Justiça brasileira, costumeira e corretamente criticada justamente pelas infindáveis possibilidades de ataque às suas decisões (ministro Joaquim Barbosa, p.7).

Admitidos os embargos para quatro votos - os cabalísticos quatro votos -, volto a dizer, e por que não três, e por que não dois, e por que não um, e por que não zero, se se trata de controlar um tribunal juvenil de irresponsáveis que não sabem como votam? É essa a lógica. A lógica está na eternização das demandas, na demora, no alongamento indevido, com o comprometimento do postulado constitucional que diz que a prestação jurisdicional deve ser célere.(...) Presidente, nós estamos a falar de uma questão institucional muito relevante. A prosseguirmos nessa toada, volto a repetir, dos embargos infringentes, que serão julgados Deus lá sabe quando, novos embargos de declaração serão opostos, que serão sucedidos por revisão criminal e, possivelmente, aí, novos embargos infringentes. Ou queremos fazer isso apenas para este caso? Qualquer que seja a resposta, Presidente, é evidente o constrangimento (ministro Gilmar Mendes, p.190).

Vossa Excelência avalie a repercussão que isto terá para a magistratura como um todo, que hoje está olhando este Tribunal com orgulho, porque sabe que o Tribunal rompeu com essa tradição de impunidade.

É preciso que se preste atenção exatamente na repercussão que essa decisão terá no âmbito dos jovens juízes que militam em todas as instâncias, que não dão esse favor, porque não podem aplicar. Isso tem consequências no sistema. Vossa Excelência disse muito bem: o sistema não fecha. Não fecha, porque não se consegue estender; porque, se fosse um direito humano, natural, seria estendido. Ora, por que não embargos infringentes agora nas punições que os pais aplicam aos filhos? Por que não em todas as relações? (ministro Gilmar Mendes, p.225226)

Outro argumento de retórica extrajurídica utilizado foi o relacionado ao aumento do número de processos a serem julgados caso o STF admitisse os embargos infringentes: 
O SENHOR MINISTRO GILMAR MENDES -Só mais um ponto, se Vossa Excelência me permitir. Nós temos hoje em tramitação no Tribunal quatrocentas ações penais originárias. Vamos agora adotar embargos infringentes?

O SENHOR MINISTRO MARCO AURÉLIO - E as repercussões gerais? Há tribunais alugando galpões para colocar os processos sobrestados que aguardam a palavra do Supremo.

O SENHOR MINISTRO RICARDO LEWANDOWSKI - Vamos aumentar as sessões, duplicá-las.

O SENHOR MINISTRO GILMAR MENDES - Certamente, à noite, aos sábados, aos domingos.

O SENHOR MINISTRO MARCO AURÉLIO - Concordo, porque o meu pique, passados 34 anos de judicatura, ainda é juvenil!

Outros ministros também trouxeram à baila julgamentos posteriores à Lei 8.038/90 em que o STF, quando examinou o cabimento dos embargos infringentes, não declarou que o dispositivo regimental estava revogado ${ }^{116}$. Por outro lado, os ministros favoráveis ao desprovimento do Agravo Regimental alegavam que o STF já havia entendido que (i) no caso da Ação Rescisória, o número de votos dissidentes exigidos para os embargos infringentes era aquele previsto no Código de Processo Civil e não no Regimento Interno (AR 1472); (ii) no caso da Ação Direta de Inconstitucionalidade, o art.333, IV, teria sido revogado pelo art.26 da Lei 9868/99, que determinou a irrecorribilidade das decisões (ADIn 1591) e (iii) no caso de ações penais originárias de tribunais inferiores, aplicar-se-ia a norma do art.609, do CPP, sendo os embargos infringentes oponíveis apenas em sede de apelação ou de recurso em sentido estrito (HC 72465).

No que se refere à questão da existência ou não de precedentes, o curioso é que, ressalvada a discussão inicial aqui mencionada sobre o obter dicta, os demais ministros pareciam mais preocupados em negar que tenham mudado de opinião do que em discutir por que os julgamentos anteriores tratavam de aspectos distintos, não podendo funcionar como argumento no caso da $\mathrm{AP} \mathrm{n}^{\circ} 470$. A ministra Carmen Lúcia, por exemplo, afirmou:

Senhor Presidente, Senhores Ministros, gostaria de fazer três observações iniciais. A primeira, pedindo licença ao Ministro Marco Aurélio, que, em data de ontem

${ }^{116}$ Como exemplo, os julgados trazidos pelo ministro Ricardo Lewandowski: ADI 29-EI/RS, Rel.Min. Marco Aurélio; Rcl 377-EI-AgR/PR, Rel. Min. Moreira Alves; ADI 1.591-EI, Rel. Min. Sepúlveda Pertence; AI 828.792-AgR-EI/SP, Rel. Min. Ricardo Lewandowki; AI 617.763-AgRED-AgR-ED/RS, Rel. Min. Cezar Peluso. (p.163) 
enfatizou, e Vossa Excelência também: este é um julgamento - a matéria específica, o núcleo da discussão - que não tem precedentes específicos. Trago aqui alguns casos meus, decisões monocráticas, e até um acórdão, nos quais fiz referência ao artigo 333 do Regimento Interno para afirmar que, naqueles que eram casos de habeas corpus, não cabiam os Embargos, e, nem se fosse em face daquele dispositivo, não caberiam. Portanto, não fiz esta análise que estamos fazendo relativamente ao inciso I do artigo 333. Digo isso para não ficar a impressão de que haveria mudança de tendência ou de que haveria um comportamento inovador. Não! As referências feitas eram basicamente em habeas corpus, quer em decisões monocráticas, quer em caso de um acórdão, nos quais não conhecia por incabíveis embargos infringentes, e, fazendo referência aos precedentes, que sempre eram nesse mesmo tipo de ação, eu fiz referência ao artigo 333, praticamente transcrevendo, sem fazer qualquer anotação sobre a sua subsistência, sobre a sua validade. E a ênfase é apenas para, secundando o que foi afirmado ontem, tanto por Vossa Excelência, Presidente, quanto pelo Ministro Marco Aurélio, reafirmar a inexistência de ter havido, pelo menos da minha parte, antes, exame detalhado sobre a subsistência ou não do dispositivo, embora tenha feito referência ao artigo 333 para dizer que não se conhecia, daquele caso, porque incabível, e, portanto, não detalhei e não adentrei o exame da matéria (p.144).

Entretanto, a tese da ministra Carmen Lúcia é, no mínimo, discutível, já que, se ela utilizou o artigo 333, do RI/STF, como base normativa para negar o cabimento de embargos infringentes a espécies processuais não contidas em seus incisos, ela reconheceu a validade destes dispositivos. Ou seja, a lógica de seu argumento era de que só caberiam embargos nas hipóteses taxativamente elencadas pelo art.333. Se partisse da revogação do artigo como premissa, teria que utilizar outras normas processuais penais para justificar por que não admitiria o recurso em habeas corpus. A menção reiterada ao art.333 do RI/STF leva a crer que a ministra entendia que este era o artigo que disciplinava os embargos infringentes perante o STF, ainda que a admissibilidade deste recurso não estivesse prevista em nenhuma outra legislação específica.

O Marco Aurélio, por sua vez, declarou:

Presidente, ouvi muito versarem-se precedentes e chegou-se mesmo a sinalizar que Turma do Tribunal poderia ter julgado embargos infringentes. Foram mencionados pronunciamentos das Turmas sobre a matéria. Reafirmo, Presidente - a menos que a idade já esteja a gerar esclerose -, que não há, sobre o tema, um único precedente. Pode haver, sim, opinião de relator, lançada à margem da matéria envolvida em certo processo, por isso, sou contrário a inserir-se, na solução de uma causa com balizas subjetivas e objetivas próprias, ideias a ela estranhas (p.232). 
A negativa sobre a existência de precedente passa ao largo, porém, de que pelo menos uma das decisões do plenário, a mais antiga delas, afirma expressamente que a Lei $\mathrm{n}^{\circ}$ 8.038/90 não revogou artigo do regimento interno porque não foi exauriente em matéria de recursos e ações no âmbito do Supremo. Tratou, portanto, da possível antinomia entre RI/STF e Lei $n^{\circ}$ 8.038/90, cerne da discussão nos autos do $26^{\circ}$ AR na AP n470. Seria possível contra argumentar que o cabimento dos embargos infringentes não foi apreciado no bojo de nenhuma ação penal originária anterior ${ }^{117}$, mas apenas em outros tipos de demandas. Entretanto, como os ministros pareciam mais interessados em negar uma possível mudança de opinião, esta questão não foi profundamente discutida através de uma comparação minuciosa das “balizas subjetivas e objetivas” de cada um dos casos.

Sobre o tema, Fernando Ângelo Leal (2015), partindo do exemplo do HC 127.186/PR, observa que, nos votos dos ministros do Supremo, não há cotejo entre o caso atual e os casos que serviram de base para a definição dos precedentes invocados, parecendo ser aleatório o seu papel na justificação de cada decisão. Nesse sentido, os precedentes deixam de funcionar como limites para o julgador e passam a servir como oportunidades: “fontes praticamente inesgotáveis para a sustentação de inúmeros pontos de vista.”

Não se pretende aqui defender que a corte adotasse uma lógica de vinculação ao precedente, que não faz parte de nossa tradição jurídica. Entretanto, diante da dificuldade de chegar a um consenso, o uso da jurisprudência seria de grande valia, prestigiando-se a segurança jurídica ${ }^{118}$. É que a não atribuição de força vinculante ao precedente não impede que o tribunal dialogue com os julgados anteriores, justificando porque se deixou ou não persuadir por suas

\footnotetext{
${ }^{117}$ Este ponto foi levantado pelo ministro Fux nos debates, mas se perdeu na leitura dos votos.

${ }^{118}$ No mesmo sentido, Fernando Ângelo Leal (2015) assinala que: "Quando são chamados a decidir, os ministros do Supremo podem até se sentir pressionados pelas decisões que a corte tomou no passado e, mesmo assim, podem divergir sobre qual decisão os vincula, o que em cada decisão os vincula ou sobre quais devem ser os critérios usados para lidar com uma decisão anterior. O problema maior é de manejo dos julgados passados. Em todas as hipóteses explicativas, porém, o efeito é o mesmo: os precedentes da corte não são capazes de dar pistas sobre a solução de casos futuros no próprio tribunal. Com um acervo que serve para sustentar qualquer conclusão, as decisões do tribunal cumprem o papel oposto ao que delas se espera. Em vez de maior previsibilidade, sobra desorientação. A manutenção dessa prática pode até ser positiva para os ministros, que sempre poderão recorrer a um julgado passado, não importa o que decidam. Mas, com menos consistência e previsibilidade, perdem a instituição e a sociedade.”
} 
razões ${ }^{119}$. Não se negam aqui todas as dificuldades relacionadas a identificar em que medida um caso anterior possui similaridades suficientemente relevantes para servir de embasamento para a solução de um caso atual. Tampouco se pretende defender que a utilização deste tipo de mecanismo elimina completamente o juízo subjetivo e ideológico dos julgadores. O que se questiona é a pouca atenção destinada a este tipo discussão, principalmente, se compararmos o destaque dado a alegações ligadas à imagem do Judiciário, ao possível aumento da carga de trabalho do STF e até ao direito comparado ${ }^{120}$. É como se valores como a estabilidade e a consistência do sistema de tomada de decisão tivessem pouca ou nenhuma importância diante destes outros aspectos.

Admitir que as menções ao art.333, do RI/STF, teriam sido realizadas em julgamentos anteriores como “opinião do relator lançada à margem da matéria” ou “sem exame detalhado da subsistência ou não do dispositivo” não livra o tribunal de parecer casuístico quando, justamente diante de um julgamento de grande repercussão, resolve se debruçar sobre a possível revogação de um artigo utilizado de forma recorrente para motivar outras decisões. O problema na fundamentação existiria de qualquer forma: ou a corte estava citando um artigo revogado de forma descuidada em várias decisões anteriores, revelando que não está atenta ao apresentar razões de julgamento, ou adotou o entendimento pelo não cabimento do recurso especificamente neste caso para abreviar o fim do processo do mensalão. De ambas as formas, o tribunal parece ter ficado aquém das expectativas quanto ao atendimento dos cânones de racionalidade decisória.

Mais uma vez, a questão não se resume à intervenção do STF no mundo da política, mas abrange a forma como ela ocorre. Considerações relativas à estabilidade e à segurança jurídica fazem parte da racionalidade esperada da deliberação jurisdicional. Ainda que se reconheça que fatores como a

\footnotetext{
119 Maurício Requião chama atenção para as diferenças conceituais entre decisão judicial, precedente e jurisprudência, afirmando que nem toda decisão tem força para gerar precedente. Apesar disso, "quando o juiz responde a uma pergunta que lhe é dirigida no âmbito de uma ação, firmando determinado entendimento, decidindo de certa maneira, ele está criando uma expectativa de decisões futuras semelhantes para casos semelhantes. Dito de outra forma, isso quer dizer que a decisão ali prolatada, que levou em conta determinados aspectos factuais e jurídicos, é algo que servirá como referência para futuras decisões. Há aqui um raciocínio similar ao da decisão por analogia: situações semelhantes devem receber tratamento semelhante, pois o sistema jurídico para seu bom funcionamento depende de pressupostos como a preservação da confiabilidade e da igualdade. Existe uma necessidade de coerência do sistema”(2013, p.3).

${ }^{120} \mathrm{O}$ voto do ministro Luiz Fux traz um apanhado da questão do duplo grau de jurisdição na jurisprudência da Espanha, da Colômbia e da Corte Europeia de Direitos Humanos.
} 
credibilidade do Judiciário sempre serão levados em conta no momento de decidir, quando não há uma racionalização da parte técnico-jurídica, o resultado final parece ficar legado ao sabor da conveniência pessoal da maioria dos ministros e a atuação da corte não se diferencia significativamente do tipo de política realizada nas demais esferas. Ao contrário, o produto da sua influência no cenário institucional soa caótico e a corte, “ingovernável”121.

Nesta seara, é importante registrar que advogar por esta maior racionalização não significa depositar confiança excessiva em métodos e teorias decisórias. Como alerta Fernando Ângelo Leal (2016), a utilização destes métodos pode reduzir os custos decisórios, mas não é capaz de eliminar completamente a subjetividade do tomador de decisão. Entretanto, em um cenário de incertezas sobre as respostas que um tribunal pode dar a problemas constitucionais, algum grau de confiança nestes métodos é necessário para que se alcance uma garantia mínima de previsibilidade e administração da subjetividade judicial. Nesse sentido:

Se, portanto, é correto afirmar que um modelo de legitimação racional da jurisdição constitucional precisa confiar em métodos e teorias de decisão, é preciso não desconsiderar as limitações epistêmicas dos responsáveis pela sua aplicação efetiva e a tentação de tornar todo e qualquer problema jurídico uma questão constitucional ou, ainda, a de compreender todo problema constitucional como um tipo de problema que exige a manipulação de muitas variáveis, como elementos morais, aspectos econômicos, o "sentimento social, o espírito do (...) tempo de o sentido da história”, a ponderação de princípios, a concretização de compromissos constitucionais vagos e mesmo a consideração de regras incidentes. Sem métodos confiáveis de decisão capazes de garantir algum tipo de racionalidade - em termos de previsibilidade e controle de discricionariedade para decisões baseadas na consideração de tantos aspectos, provavelmente a legitimidade da jurisdição constitucional tornar-se-ia uma função exclusiva da virtude dos tomadores de decisão. Superar essa possibilidade me parece ser o primeiro limite para o êxito de uma tentativa de legitimar, pela racionalidade acoplada à fundamentação das decisões, a jurisdição constitucional em uma democracia.

Percebe-se, assim, que a performance política do tribunal fica seriamente comprometida quando os instrumentos de controle de sua atuação parecem incertos e a própria corte não parece investir em mecanismo reais de transparência. Mesmo que eventualmente se concorde com o resultado final

${ }^{121}$ Expressão" utilizada por Conrado Hübner Mendes em entrevista concedida ao Blog "Os Constitucionalistas". Disponível em: <http://www.osconstitucionalistas.com.br/conrado-hubnermendes-o-stf-e-refem-do-capricho-dos-seus-ministros>. Acesso em: 15 set. 2016. 
alcançado pelo tribunal, fica difícil defender sua intervenção no jogo político quando o processo de tomada de decisão não só está longe dos critérios ideais da legitimação discursiva, mas também dificulta sobremaneira uma maior supervisão da sociedade. A complexidade dos argumentos técnicos se mistura à retórica metajurídica em um amálgama impossível de destrinchar para o público em geral sem a existência de qualquer horizonte de objetividade a constranger os julgadores.

\section{3.}

\section{Quantidade de recursos políticos à disposição}

A quantidade de recursos políticos disponíveis funciona para legitimação da jurisdição constitucional se associada com sua capacidade argumentativa. Afinal, a superioridade advinda da não utilização de armas políticas tradicionais teria como ponto de apoio o fato de que o juiz estaria submetido a uma exigência argumentativa muito mais intensa do que agentes políticos. Enquanto estes últimos poderiam fazer campanha na mídia, comício ou populismo assistencialista (MENDONÇA, 2008), o julgador estaria constrangido ao processo judicial e a argumentos de razão pública. Em outras palavras, enquanto o político poderia seduzir seu eleitorado com uma bela retórica, o ministro da corte superior teria que construir uma argumentação sólida baseada no ordenamento jurídico para convencer os jurisdicionados.

O tema, de certa forma, já foi tratado no tópico acima. Entretanto, valeria investigar a premissa de que o arranjo constitucional que privilegia a jurisdição constitucional é superior porque o órgão de controle não possui os recursos políticos tradicionais (mesmo que se reconheça que dispõe de outros tipos de recursos desta natureza). Afinal, até que ponto as armas políticas que o STF detém são mais “inofensivas” que aquelas à disposição dos representantes eleitos? A corte depende da opinião pública para sua legitimação? Caso sim, basta um bom argumento jurídico para conquistá-la?

Para Barroso e Mendonça (2012), o Judiciário “deve ser permeável à opinião pública, o que não significa que deva ser subserviente”. Seria justamente 
na busca deste equilíbrio que suas armas políticas seriam colocadas à mostra: em determinados momentos, o tribunal precisa escolher entre defender minorias ou se alinhar à vontade majoritária, entre decidir de forma impopular ou amoldar seu julgamento de maneira a aumentar seu capital institucional. Precisa, também, ponderar sua independência decisória com a necessidade da adoção de medidas que garantam a eficácia de suas decisões. Com os agentes políticos, o eleitor alimenta uma expectativa legítima que ele assuma determinados posicionamentos com os quais se comprometeu na campanha. Caso não o faça, a sanção é não ser reeleito. Com os juízes, esta metadecisão não possui mecanismo de controle que não seja a análise dos fundamentos decisórios. Enquanto a retórica da decisão garantir a credibilidade da corte, os requisitos de legitimação parecem ter sido atendidos.

Mas será que o potencial político da fundamentação das decisões do STF é desprezível se comparado a uma campanha eleitoral? O ex-ministro Joaquim Barbosa, por exemplo, no final de 2012, segundo pesquisa do Datafolha, tinha 10\% das intenções de voto para Presidência da República, aparecendo em terceiro lugar entre os potenciais candidatos. Em junho de 2013, ele apareceu em segundo lugar com 30\% dos votos de acordo com o mesmo instituto de pesquisa, na frente, portanto, de políticos experientes como o Senador Aécio Neves. Mesmo depois de sua aposentadoria, em 29.02.2016, o ex-ministro ainda figurava como a personalidade mais confiável dentre as doze selecionadas pelo Datafolha levando em conta a conjuntura política do país ${ }^{122}$. Ainda conforme esta pesquisa, na terceira posição, estavam empatados o Senador Aécio Neves, o ex-presidente Fernando Henrique Cardoso e o juiz Sérgio Moro, outro representante do Poder Judiciário em lugar de destaque no ranking.

O que extrair destes dados? Será que estaríamos diante de um subdimensionamento do potencial político do discurso judicial e um hiperdimensionsamento dos argumentos de razão pública deste Poder? Esta conclusão talvez seja precipitada, mas a indagação pode contribuir para chamar a atenção para o uso mais frequente de estratégias políticas na motivação das decisões, entendidas aqui como uma argumentação que tem como alvo a

\footnotetext{
122 Disponível em: <http://datafolha.folha.uol.com.br/opiniaopublica/2016/02/1744619-joaquim-
} barbosa-e-mais-confiavel-entre-12-personalidades-do-pais.shtml>. Acesso em: 19 set. 2016. 
audiência externa ao tribunal. Isto não significa que o juiz que lance mão destas estratégias tenha, necessariamente, a intenção de disputar uma eleição para cargos da política representativa, mas pode sinalizar para um apelo à opinião pública que não diverge tanto daquele de que os candidatos a cargos eletivos necessitam e realizam. O problema desta postura é que ela afeta diretamente os mecanismos de controle: se a análise dos fundamentos da decisão deveria ser o meio apto a submeter o tribunal ao crivo público, este tipo de discurso, que mais se assemelha a uma campanha política, compromete uma avaliação isenta baseada na qualidade dos argumentos. Quando o tribunal ou os seus membros investem no culto à personalidade do julgador, a figura midiática construída pode afetar a efetividade da crítica pública.

Mais uma vez, o televisionamento ao vivo das sessões de julgamento tem uma contribuição relevante. Estudando os efeitos da TV Justiça sobre os ministros, Joana Machado de Souza (2014) alerta para o risco de o Poder Judiciário, diante das câmeras, ceder à tentação populista, acreditando encarnar o sentimento mais profundo e real do povo. Os telespectadores, por outro lado, precisam lidar com os perigos relacionados ao mito da transparência ${ }^{123}$ no acompanhamento das sessões de julgamento:

O público espectador, corre, por sua vez, o risco de cair na armadilha da ilusão de um acesso livre à verdade produzida pelos juízes, que no Brasil ainda têm visível dificuldade em assumir a natureza política que em boa medida contorna a sua função.

A transmissão ao vivo dos julgamentos vende a sensação aos espectadores de constituírem testemunhas oculares da produção da justiça, ofuscando-lhe a mediação realizada, a diferença entre o olhar despido e o olhar aparelhado.

Impõe-se uma lógica de espetáculo aos juízes e demais atores, que, sabidamente observados, podem desencadear ações performáticas, administrando suas imagens e interesses diversos, sem necessariamente fazer prevalecer razão pública sobre razões privadas. Juízes são promovidos a celebridades, quase onipresentes pela via tecnológica. A aproximação prometida por meio da presença de câmeras nos tribunais poder em última análise falaciosa, na medida em que o objeto tende a se alterar diante do observador.

\footnotetext{
${ }^{123}$ O ministro Luiz Fux, em entrevista concedida para o projeto História Oral do Supremo da FGV, não faz uma avaliação positiva da deliberação diante das câmeras: "Eu acho que é o tipo de transparência hipócrita. Eu prefiro mais assim...Se a TV Justiça servisse para que, por exemplo, nós anunciássemos resultados, algum de nós fosse indicado para ser porta-voz do colegiado, explicasse a decisão. Agora, debate público...O ser humano é o ser humano. Já imaginou se a pessoa te filma no chuveiro? (...)” (p.109)
} 
São vários os exemplos em que ministros, em meio à fundamentação de seus votos ou simplesmente utilizando-se do espaço das sessões de julgamento, introduzem discursos voltados ao grande público, como pode ser observado em trecho do voto da ministra Cármen Lúcia durante o julgamento da Ação Cautelar nº3039, que tratava da prisão preventiva do Senador Delcídio do Amaral:

Um aviso aos navegantes dessas águas turvas de corrupção e iniquidades: criminosos não passarão a navalha da desfaçatez e da confusão entre imunidade e impunidade e corrupção. Não passarão sobre os juízes, e há juízes no Brasil. Não passarão sobre novas esperanças do povo brasileiro.

O ministro Celso de Mello, em pronunciamento durante a sessão plenária de 17.03.2016, logo após a divulgação na imprensa do conteúdo de grampos telefônicos envolvendo o ex-presidente Lula, proferiu manifestação repleta de frases de efeito, destacando o papel do Supremo na repressão ao crime e na promoção da justiça:

Os meios de comunicação revelaram, ontem, que conhecida figura política de nosso País, em diálogo telefônico com terceira pessoa, ofendeu, gravemente, a dignidade institucional do Poder Judiciário, imputando a este Tribunal a grosseira e injusta qualificação de ser "uma Suprema Corte totalmente acovardada"! Esse insulto ao Poder Judiciário, além de absolutamente inaceitável e passível da mais veemente repulsa por parte desta Corte Suprema, traduz, no presente contexto da profunda crise moral que envolve os altos escalões da República, reação torpe e indigna, típica de mentes autocráticas e arrogantes que não conseguem esconder, até mesmo em razão do primarismo de seu gesto leviano e irresponsável, o temor pela prevalência do império da lei e o receio pela atuação firme, justa, impessoal e isenta de Juízes livres e independentes, que tanto honram a Magistratura brasileira e que não hesitarão, observados os grandes princípios consagrados pelo regime democrático e respeitada a garantia constitucional do devido processo legal, em fazer recair sobre aqueles considerados culpados, em regular processo judicial, todo o peso e toda a autoridade das leis criminais de nosso País! A República, Senhor Presidente, além de não admitir privilégios, repudia a outorga de favores especiais e rejeita a concessão de tratamentos diferenciados aos detentores do poder ou a quem quer que seja. Por isso, Senhor Presidente, cumpre não desconhecer que o dogma da isonomia, que constitui uma das mais expressivas virtudes republicanas, a todos iguala, governantes e governados, sem qualquer distinção, indicando que ninguém, absolutamente ninguém, está acima da autoridade das leis e da Constituição de nosso País, a significar que condutas criminosas perpetradas à sombra do Poder jamais serão toleradas, e os agentes que as houverem praticado, posicionados, ou não, nas culminâncias da hierarquia governamental, serão punidos por seu Juiz natural na exata medida e na justa 
extensão de sua responsabilidade criminal! Esse, Senhor Presidente e Senhores Ministros, o registro que desejava fazer. ${ }^{124}$

Já o ministro Gilmar Mendes, em diversas oportunidades, repetiu que "ninguém se mantém no cargo com liminar do Supremo"125. A frase foi dita, inicialmente, em outubro de 2015, a propósito de liminares que suspenderam o rito definido pelo então presidente da Câmara, Eduardo Cunha, para o processo de impeachment de Dilma Rousseff. Em 18.04.2016, em entrevista ao programa Roda Viva da TV Cultura, o ministro voltou a afirmar: "O presidente, quando não consegue evitar impeachment, é porque está numa situação delicada. [...] Se o presidente não consegue 171, 172 votos [na Câmara], é porque não tem condições de governar. Ele não vai ser mantido no cargo por liminar do Supremo."126 Posteriormente, em meio ao julgamento dos Embargos de Declaração na ADPF ³78, repetiu o discurso com mais veemência:

Para que eleição? O que estamos dizendo, a rigor, é que cabe a uma oligarquia a designação desses membros. E, veja, com reflexo em todo o funcionamento da Câmara. Estamos manipulando esse processo com eficácia próxima de zero, senão zero, porque não se salva quem precisa de força política com esse balão de oxigênio dado por Corte judicial.

E, por isso, votava no sentido de integralmente apoiar o voto do ministro Fachin. Já disse, Presidente, e o quadro aqui narrado agravou-se muito nesses pouco mais de dois meses, sem dúvida nenhuma. Não houve nenhuma alteração para melhor. A economia, com esse quadro de descalabro. (...) E o quadro se agrava. Agora, temos ainda essa medida, a nomeação do ex-Presidente da República para o cargo de Chefe da Casa Civil, que vem na condição de ser um supertutor da Presidente da República. E vem para fugir também da investigação que se faz em Curitiba, deixando este Tribunal muito mal no contexto geral. Muito mal. É preciso muita desfaçatez para obrar dessa forma com as instituições. É preciso ter perdido aquele limite que distingue civilização de barbárie. É atitude de barbárie o que se está fazendo com as instituições.(p.84)

(...)

A rigor, a rigor, e não estou inovando nessa parte, mas repetindo uma frase que ouvi, à época, de um colega do Supremo Tribunal Federal no caso Collor, quando se tratava da discussão sobre vários mandados de segurança e várias impetrações, a discussão, inclusive, sobre a questão do voto secreto e do aberto. Diante de algumas ponderações, dizia ele que se o Presidente não consegue, não logra cento e setenta e um votos para impedir a tramitação, o início do processo do

124 Disponível em: <http://politica.estadao.com.br/blogs/fausto-macedo/leia-a-manifestacao-doministro-celso-de-mello-em-reacao-a-lula-no-grampo/> . Acesso em: 10 mar. 2017.

${ }^{125}$ Disponível em: <http://jota.uol.com.br/ninguem-se-mantem-no-cargo-por-liminar-do-supremodiz-gilmar-mendes>. Acesso em: 26 set. 2016.

$126 \quad$ Disponível em: <http:/g1.globo.com/politica/processo-de-impeachment-dedilma/noticia/2016/04/gilmar-diz-que-sem-171-votos-na-camara-presidente-nao-governa.html>.

Acesso em: 26 set. 2016. 
impeachment, não tem condições de continuar no cargo. Simples assim. E sabedores, todos nós, de que esta questão é condição para alguma governabilidade - não é condição, é necessário -, mas não é suficiente, porque com cento e setenta e um votos não se governa na Câmara dos Deputados, como estamos a ver. (p.117)

A insistência do ministro neste ponto sugere uma tentativa de convencer a opinião pública de que a intervenção do STF no procedimento de impeachment deva ser reduzida, já que uma eventual decisão judicial não teria força de suprir a falta de apoio político da Presidente. Ao lançar mão de argumentos extrajurídicos, como a situação econômica do país ou a nomeação do ex-presidente Lula para a Casa Civil, parece buscar aceitação para a sua "metadecisão” de não interferir no curso do processo de impedimento de Dilma Rousseff.

O ministro Joaquim Barbosa, por sua vez, ao longo do julgamento da AP $n^{\circ} 470$, também lançou mão de retórica política, principalmente, em momentos de discordância entre os membros do tribunal. Ao debater com seus pares no plenário, o ministro, muitas vezes, se colocava como aquele imbuído do ânimo de combate à corrupção e à impunidade, desqualificando as opiniões divergentes com insinuações de que estas não estariam movidas pelo mesmo espírito. Na sessão de 26.02.2014, diante do voto do ministro Luís Roberto Barroso que absolvia os réus do crime de formação de quadrilha, acusou-o de pretender modificar decisão tomada pelo colegiado anteriormente por razões suspeitas:

É fácil fazer discurso político, ministro Barroso. É muito simples dizer que o sistema político é corrupto, e quando se tem a oportunidade de usar o sistema jurídico para coibir essas nódoas, se parte para a consolidação daquilo que se aponta como destoante.

(...)

Vossa Excelência chega aqui com a fórmula prontinha, já proclamando inclusive o resultado do julgamento. Na sua chamada preliminar de mérito, Vossa Excelência já disse qual é o placar, antes mesmo que o colegiado tivesse votado. A formula já é pronta. Eu indago se Vossa Excelência já tinha antes de chegar a este tribunal. Parece que sim.

(...)

O tribunal não deliberou no vácuo, não exerceu arbitrariedade. Os fatos são gravíssimos, de maneira que trazer para o plenário do Supremo Tribunal Federal um discurso político, puramente político, para infirmar a decisão tomada por um colegiado, em um primeiro momento, confirmada em embargos de declaração. Isso me parece inapropriado, para não dizer outra coisa. 
No dia seguinte, na sessão do dia 27.02.2014, o ministro Joaquim Barbosa prosseguiu em seu discurso:

Temos uma maioria formada sob medida para lançar por terra o trabalho primoroso desta Corte no segundo semestre de 2012. Isso que acabamos de assistir. Inventou-se um recurso regimental totalmente à margem da lei com o objetivo específico de anular a reduzir a nada um trabalho que fora feito. Sintome autorizado a alertar a nação brasileira de que esse é apenas o primeiro passo. É uma maioria de circunstância que tem todo o tempo a seu favor para continuar sua sanha reformadora.

Estes episódios contribuíram para as expectativas de que Joaquim Barbosa se lançasse candidato à Presidência da República após sua saída do Supremo em 2014, ainda sustentado por sua fama de “justiceiro" (em 2013, foi eleito uma das 100 pessoas mais influentes do mundo pela revista Time) e pela a popularização do apelido de "Batman”127. Em entrevista concedida ao jornalista Roberto D’Ávila em 22.03.2014 ${ }^{128}$, quando ainda era presidente da corte, o ministro afirmou que não descartava a hipótese de um dia se lançar à vida política, mas que não o faria naquele momento. Neste contexto, sua performance no caso do mensalão permitiu a construção de um personagem na grande imprensa, que reuniria as qualidades necessárias para solucionar os problemas da política no Brasil. Antoine Garapon descreve os perigos da relação dos juízes com a mídia:

A tentação populista se caracteriza, antes de mais nada, por sua pretensão a um acesso direto à verdade. Alguns indivíduos aproveitam a mídia para se emancipar de qualquer tutela hierárquica. Ela lhes oferece um acesso direto, conforma expressão de Perelman, ao 'auditório universal', quer dizer, opinião pública. Um juiz considera-se prejudicado por sua hierarquia? Ele apela imediatamente para a arbitragem da opinião pública. Todas as anulações processuais são purgadas por essa instância de recurso selvagem que a mídia representa, e os argumentos técnicos do direito ou processuais não tardam a revelarem-se para a opinião pública como argúcias, astúcias, desvios inúteis, que impedem a verdade de 'vir à tona’. A busca direta da aprovação popular por intermédio da mídia, acima de qualquer instituição, é uma arma temível à disposição dos juízes, o que torna muito mais presente o desvio populista. O populismo, com efeito, é uma política que pretende, por instinto e experiência, encarnar o sentimento profundo e real do povo. Esse contato direto do juiz com a opinião é proveniente, além disso, do

\footnotetext{
$127 \quad$ Disponível em: <http://www.brasilpost.com.br/2014/05/29/joaquim-barbosabatman_n_5412578.html>. Acesso em: 21.set. 2016.

128 Disponível em: <https://www.youtube.com/watch?v=0EtEJzGNpcM>. Acesso em: 21 set. 2016.
} 
aumento do descrédito do político. O juiz mantém o mito de uma verdade que se basta, que não precisa mais da mediação processual (2001, p.66).

No caso brasileiro, ainda que o membro do tribunal não se exponha de forma excessiva em veículos de imprensa, o televisionamento das sessões de julgamento permite um elo direto a ser construído com o grande público. Ao desqualificar $^{129}$ os argumentos dos colegas com acusações de parcialidade ${ }^{130}$, o ministro Joaquim Barbosa conseguia, assim como observado por Garapon no trecho acima transcrito, dar às alegações técnicas uma aparência de discurso vazio voltado a impedir a condenação dos réus. O seu tom firme de combate à corrupção se mostrava muito mais persuasivo à opinião pública que argumentos tipicamente jurídicos como os relativos à dosimetria da pena ou à prescrição. Para a audiência, construía-se a imagem do justiceiro que se contrapunha àqueles que defendiam interesses espúrios e buscavam perpetuar a impunidade.

A adoção deste tipo de postura também vai de encontro ao ideal de deliberação já mencionado anteriormente, segundo o qual, ao contrário do Legislativo, o Judiciário trabalharia como um time, buscando minimizar os efeitos da racionalidade limitada e alcançar um consenso. Quando este tipo de discurso é adotado, o alvo principal se torna o público externo, a ênfase passa a ser em argumentos extrajurídicos e o diálogo para a formação de uma posição comum torna-se praticamente impossível. Ademais, a concepção de uma jurisdição despersonalizada fica irremediavelmente afetada e, ao invés do fortalecimento do STF como instituição, há a consolidação de poderes individuais calcados em idiossincrasias de seus detentores.

A possibilidade de apelo direto à opinião pública, portanto, desmistifica a ideia do juiz constrangido pelo processo e pela necessidade de apresentação de

\footnotetext{
${ }^{129}$ Desqualificar o adversário da discussão também atenta contra a racionalidade do discurso, como observa José Rodrigo Rodriguez (2013): "Mas o que significa, nesse contexto, um discurso racional? Lembremos, em poucas palavras, que um discurso racional é aquele em que os falantes levantam pretensões de validade e são capazes de defende-las, sem entrar em contradição, quando instados a fazê-lo. Não se pode sustentar, racionalmente A e não A simultaneamente. Não se pode recusar, racionalmente, a justificar uma asserção proferida quando alguém se põe a questioná-la, também não se pode, racionalmente, desqualificar o interlocutor que demanda por minhas razões ou impedir que qualquer outro faça o mesmo.” (p.173)

${ }^{130}$ Além do caso citado, o ministro adotou esta postura em outras várias situações. Por exemplo, em setembro de 2012, durante uma das sessões de julgamento da AP nº 470, Joaquim Barbosa acusou o ministro Ricardo Lewandowski de fazer "vista grossa” em relação aos fatos descritos nos autos.
} 
argumentos de razão pública. Nesse sentido, as tentações populistas, quando manifestadas no Judiciário, podem surtir efeitos até mais graves que nos outros Poderes, onde este tipo de postura é esperado. Quando aquele que seria o órgão técnico seduz a opinião pública, o personagem criado tem sua credibilidade reforçada pelo monopólio do saber jurídico. O controle que seria exercido com base no dever de fundamentação das decisões fica, assim, refém do apoio popular conquistado pela retórica de efeitos midiáticos.

A performance política do STF, neste cenário, torna-se problemática não necessariamente pelos temas a serem decididos ou pelo resultado do julgamento, mas porque o tribunal se torna uma instância que trafega livremente entre o discurso político e o jurídico com pouquíssimos mecanismos de controle institucionalizados e sem contar com o crivo público como esfera eficiente para limitação de seu poder. $\mathrm{O}$ ator que se incorpora à cena institucional se revela, assim, detentor de diversos mecanismo de intervenção na realidade política, pouco debatidos e sem balizas claras a serem impostas. 


\section{5 \\ Considerações finais}

O presente trabalho procurou demonstrar a importância da análise da dimensão política da atuação do STF, entendida não apenas como aquela interferência do tribunal em políticas públicas ou nas regras do jogo político eleitoral. O ponto aqui defendido é que esta dimensão abrange também a forma como os ministros instrumentalizam a ampla gama de recursos que está à disposição do tribunal para alcançar objetivos no âmbito da deliberação ou para produzir determinados efeitos no ambiente externo ao tribunal.

A relevância desta abordagem se manifesta, especialmente, na medida em que ela permite verificar as proporções do poder de que dispõe o Supremo. Afinal, ninguém mais discute que, nos últimos tempos, tem competido a ele a definição de questões chaves para vida pública brasileira e este fato, por si só, já representa imenso poder. No entanto, os limites (ou a ausência deles) para o exercício de suas atribuições também irão indicar o tamanho do poder de que dispõe a instituição e seus membros individualmente considerados. Os ministros podem manifestar opiniões políticas para a imprensa? Podem decidir à revelia da jurisprudência do tribunal? Podem decidir sozinhos questões altamente polêmicas? O que os ministros não podem fazer?

Todas estas potencialidades no desempenho de suas atividades compõem um personagem que precisa dialogar com as expectativas normativas criadas em torno da jurisdição constitucional. Em um primeiro momento, sedimentou-se a crença de que, enquanto o Supremo funcionasse como instância de garantia de direitos fundamentais, tudo estava bem. Se, além disso, exercesse este papel incorporando grupos da sociedade civil no processo, estaria dando sua contribuição para a construção de uma cidadania mais ativa. De fato, em países como o Brasil, que vivenciam uma realidade de extrema carência em garantias básicas da população, uma esfera que se apresente como canal de efetivação de direitos não pode ser desprezada. A legitimidade da corte seria, portanto, 
conquistada por uma racionalidade instrumental, conforme já mencionado anteriormente e observado por Leal (2017).

Entretanto, a questão se complica quando, de um lado, a régua dos direitos fundamentais não funciona para medir o desempenho do Supremo - seja porque não possui medidas objetivas, seja porque o tribunal não parece ter incorporado realmente o personagem do herói que se lança em defesa destes direitos - e, de outro, o papel que ele vem desempenhando também não tende a contribuir para que as demais perspectivas teóricas ligadas às atribuições da jurisdição constitucional se confirmem. Ainda que não se adote a ideia de supremacia, mas de uma concepção de instituição que contribui para um debate permanente sobre o sentido da Constituição, quando olhamos para o Supremo de ontem e de hoje, fica difícil enquadrá-lo na imagem delineada no âmbito teórico. É que, ao lançar mão da gama de escolhas que tinha à sua disposição para compor seu personagem político, o tribunal não investiu em elementos que incrementassem a racionalidade decisória, como, por exemplo, a consolidação de jurisprudência e a fundamentação cuidadosa, nem se revelou disposto a franquear o discurso jurídico para os demais Poderes, bem como nunca pareceu aberto à discussão sobre limites à sua atuação. Adentrou, assim, na perigosa armadilha do monopólio da verdade jurídica, mais se afastando do que se aproximando do ideal decisório que permite uma abertura efetiva ao crivo público.

Este crivo seria a grande vantagem do modelo que dá destaque à jurisdição constitucional. Ela representaria uma esfera de discussão de direitos em bases distintas daquelas utilizadas no Legislativo, não se submetendo, necessariamente, aos interesses das maiorias eleitorais, o que permitiria especial atenção às questões afetas às minorias.

No entanto, a possibilidade de crítica pública se perde na retórica das decisões e, muitas vezes, a própria técnica jurídica é utilizada não como algum norte em meio a subjetividades, mas como instrumento de uso restrito capaz de fazer valer intenções subjacentes. O espetáculo transmitido pela TV Justiça confere a aura de transparência e espontaneidade aos procedimentos do Supremo, enquanto ministros se perdem entre votos imensos permeados por considerações sobre a realidade política do país, por eventuais trocas de acusações e por manifestações mais veementes sobre questões adjacentes ao caso em julgamento. 
Paralelamente a isto, o timing decisório é utilizado para influenciar de forma mais definitiva a solução de determinadas discussões jurídico-políticas, os pedidos de vista vetam a resolução de alguns casos envolvendo interesses sensíveis e ministros se manifestam publicamente sobre questões pendentes de julgamento, passando recados a agentes externos ao tribunal. Neste quadro, não é possível apontar em que medida o desempenho da corte representaria um real incremento para o debate público sobre direitos em relação ao trabalho que vem sendo realizado pelo Congresso.

Estas observações não pretendem apontar para a inviabilidade do modelo que dá destaque à corte constitucional no Brasil. Contudo, chamam atenção para a necessidade de reflexão sobre parâmetros de controle. A teoria que se dedica a descrever, normativamente, o papel ideal da jurisdição constitucional é extremamente relevante, mas deve ser acompanhada de outra que investigue as formas de tornar sua atuação prática mais próxima deste standard. Conforme já mencionado, independência judicial não é sinônimo de ausência de supervisão e os ajustes devem ser pensados diante do caso concreto. Assumir que o Supremo detém boa dose de arbítrio no exercício de suas funções é fundamental para pensar mecanismos através dos quais a instituição possa demonstrar previsibilidade em casos rotineiros e afastar a sombra de parcialidade em casos relevantes. 


\section{6 Referências bibliográficas}

ABRANCHES, Sérgio Henrique Hudson de. Presidencialismo de coalizão: o dilema institucional brasileiro. Revista de Ciências Sociais, Rio de Janeiro, v. 31, n. 1, p. 5-34, 1988.

ABREU, Alzira Alves (coord. geral). Dicionário Histórico-Biográfico da Primeira República - 1889-1930. Rio de Janeiro: Editora FGV, 2015.

ALMEIDA, Danilo dos Santos; BOGOSSIAN, André Martins. Nos termos do voto do relator. Revista Estudos Institucionais, Rio de Janeiro, v. 2, I, 2016.

ALVES, Maria Helena Moreira. Estado e Oposição no Brasil (19641984). Bauru, SP: EDUSC, 2005.

AMARAL, Roberto. O constitucionalismo na era Vargas. Revista de Informação Legislativa. Brasília, v. 41, n. 163, p. 85-92, jul/set 2004.

ARGUELHES, Diego Werneck; RECONDO, Felipe. Nada mudou: a genealogia de uma confusão no Supremo. JOTA, São Paulo, 25 jun. 2015. Disponível em: <http://jota.info/nada-mudou-a-genealogia-de-umaconfusao-no-supremo>. Acesso em: 28 nov. 2015.

O Ministro Fux e o

"germe da inconstitucionalidade". JOTA, São Paulo, 02 out. 2015. Disponível em: <http://jota.info/o-ministro-fux-e-o-germe-dainconstitucionalidade>. Acesso em: 28 nov. 2015.

ARGUELHES, Diego Werneck; PEREIRA THOMAZ. Supremo não é inerte: PEC do parlamentarismo e dois mitos sobre o STF. JOTA, São Paulo, 15 mar. 2016. Disponível em: <http://jota.uol.com.br/supremo-naoe-inerte-pec-do-parlamentarismo-e-dois-mitos-sobre-o-stf>. Acesso em: 03 jun. 2016. 
ARGUELLES, Diego Werneck; HARTMANN, Ivar A. Mendes e Lula: uma liminar contra o Plenário do Supremo. JOTA, São Paulo, 21 mar. 2016. Disponível em: <http://jota.uol.com.br/mendes-e-lula-uma-liminar-contra-oplenario-do-supremo>. Acesso em: 03 jun. 2016.

ARGUELLES, Diego Werneck; RIBEIRO, Leandro Molhano. Preferências, Estratégias e Motivações: Pressupostos institucionais de teorias sobre comportamento judicial e sua transposição para o caso brasileiro. Revista Direito e Práxis, v. 4, n. 7, p. 85-121, 2013.

O Supremo Individual: mecanismos de atuação direta dos Ministros sobre o processo político. Direito, Estado e Sociedade, n. 46, p.121-155, jan/jun 2015.

. Criador e/ou Criatura: transformações do Supremo Tribunal Federal sob a Constituição de 1988. Revista Direito GV, v. 12, mai-ago 2016.

ARGUELLES, Diego Werneck. O Supremo e Cunha: quem decide quando quer, ouve o que não quer. JOTA, São Paulo, 07 mai. 2016. Disponível em: <http://jota.uol.com.br/o-supremo-e-cunha-quem-decide-quando-querouve-o-que-nao-quer>. Acesso em: 03 jun. 2016.

Afinal, ministro do Supremo é magistrado? JOTA, São Paulo, 15 mar. 2016. Disponível em: <https://jota.info/colunas/supra/afinalministro-do-supremo-e-magistrado-15032016>. Acesso em: 23 mai. 2017.

Poder não é querer: preferências restritivas e redesenho institucional no Supremo Tribunal Federal pós-democratização. Universitas Jus (UniCeub Law Journal), v. 25, n. 1, 2014.

. O Supremo que não erra. In VIEIRA, Oscar Vilhena; GLEZER, Rubens (org.). A razão e o voto: diálogos constitucionais com Luís Roberto Barroso. Mimeografado. 2017.

ARANTES, Rogério Bastos; KERCHE, Fábio. Judiciário e democracia no Brasil. Novos Estudos Cebrap, n. 54, 1999.

AVRITZER, Leonardo. Impasses da democracia no Brasil. Rio de Janeiro: Civilização Brasileira, 2016. 
BARBOSA, Rui. Obras Completas, volume XX, 1893, tomo IV. Disponível em: <http://www.casaruibarbosa.gov.br/rbonline/obrasCompletas.htm>. Acesso em: 18 jul. 2016.

Actos inconstitucionais do Congresso e do Executivo ante a Justiça Federal. Rio de Janeiro: Companhia Impressora 7, 1893. BARROSO, Luís Roberto; MENDONÇA, Eduardo. STF foi permeável à opinião pública, sem ser subserviente. Revista Consultor Jurídico, São Paulo, jan. 2012. Disponível em: <http://www.conjur.com.br/2012-jan03/retrospectiva-2011-stf-foi-permeavel-opiniao-publica-subserviente>. Acesso em: 04 out. 2016.

BARROSO, Luís Roberto. Judicialização, Ativismo Judicial e Legitimidade Democrática. [Syn] Thesis, v. 5, n. 1, p. 23-32, 2012. Interpretação de Aplicação da Constituição. São Paulo: Saraiva, 2009.

A ascensão política das Supremas Cortes e do Judiciário. Revista Consultor Jurídico, São Paulo, 06 jun. 2012. Disponível em: <http://www.conjur.com.br/2012-jun-06/luis-roberto-barroso-ascensaopolitica-supremas-cortes-judiciario>. Acesso em: 28 nov. 2015.

A razão sem voto: o Supremo Tribunal Federal e o governo da maioria. In SARMENTO, Daniel (coord.). Jurisdição Constitucional e Política. Rio de Janeiro: Forense, 2015.

BARROSO, Luís Roberto; FONTAINHA, Fernando de Castro; MATTOS, Marco Aurélio Vannucchi Leme de; NUÑEZ, Izabel Saenger (orgs.). História Oral do Supremo [1988-2013]: Luís Roberto Barroso, v.11. Rio de Janeiro: Escola de Direito do Rio de Janeiro da Fundação Getúlio Vargas, 2016.

BASTOS, Érico Araújo. STF e poder moderador: política à margem do Poder Constituinte na atuação do Supremo Tribunal Federal. Curitiba: Juruá, 2015. 
BRANDÃO, Rodrigo. Supremacia Judicial versus Diálogos Constitucionais: a quem cabe a última palavra sobre o sentido da Constituição? Rio de Janeiro: Lumen Juris, 2012.

BINENBOJM, Gustavo. A nova jurisdição constitucional brasileira: legitimidade democrática e instrumentos de realização. $3^{a}$ ed. Rio de Janeiro: Renovar, 2017.

BRINKS, Daniel. Judicial Reform and Independence in Brazil and Argentina: The Beginning of a New Millennium? Texas Internacional Law Journal, v. 40, issue 3, p. 595, 2005.

- Fieles servidores del regimen. El papel de la Corte Constitucional de Brasil bajo la Constitución de 1988. Tribunales Constitucionales en América Latina. HELMKE, Gretchen; FIGUEROA, Julio Ríos (coord.), Mexico: Suprema Corte de Justicia de la Nación, 2010. CÂMARA, Heloisa Fernandes. Estado de sítio na história constitucional brasileira: o início republicano sob "estado de emergência". In: CLÈVE, Clèmerson Merlin. Direito Constitucional Brasileiro: organização do Estado e dos Poderes. Rio de Janeiro: Revista dos Tribunais, 2014.

CAMPOS, Carlos Alexandre de Azevedo. Dimensões do Ativismo Judicial do Supremo Tribunal Federal. Rio de Janeiro: Forense, 2014.

CARVALHO, Ernani Rodrigues. Em busca da judicialização da política no Brasil: apontamentos para uma nova abordagem. Revista de Sociologia e Política. Curitiba, v. 23, p. 115-126, nov. 2004. Disponível em: <http://www.scielo.br/pdf/rsocp/n23/24626.pdf>. Acesso em: 03 jun. 2016.

CASTRO, Marcos Faro. O Supremo Tribunal Federal e a judicialização da política. Disponível em: <http://www.anpocs.org.br/portal/publicacoes/rbcs_00_34/rbcs34_09.htm> Acesso em: 03 jun. 2016.

CHALOUB, Sidney. Moro é o Alienista de Machado de Assis. Diário do Centro do Mundo. Disponível em: <http://www.diariodocentrodomundo.com.br/moro-e-o-alienista-de- 
machado-de-assis-por-sidney-chalhoub-de-harvard/>. Acesso em: 18 jul. 2016.

CITTADINO, Gisele. Pluralismo, direito e justiça distributiva: elementos da filosofia constitucional contemporânea. Rio de Janeiro: Lumen Juris, 2000.

COSTA, Edgard. Os grandes julgamentos do Supremo Tribunal Federal. Volume 5. Rio de Janeiro: Civilização Brasileira, 1967.

COSTA, Emília Viotti da. O Supremo Tribunal Federal e a construção da cidadania. $2^{\mathrm{a}}$ ed. São Paulo: UNESP, 2006.

DA ROS, Luciano. Tribunais como árbitros ou como instrumentos de oposição: uma tipologia a partir de estudos recentes sobre judicialização da política com aplicação ao caso brasileiro contemporâneo. Direito, Estado e Sociedade, Rio de Janeiro, n. 31, p. 86-105, jul-dez 2007.

FAORO, Raymundo. Os donos do poder: a formação do patronato político brasileiro. São Paulo: Globo, 2001.

FAUSTO, Boris. A Revolução de 1930: historiografia e história. 16ª ed. Rio de Janeiro: Companhia das Letras, 1997.

FERREIRA FILHO, Manoel Gonçalves. O Poder Judiciário na Constituição de 1988: judicialização da política e politização da justiça. Revista de Direito Administrativo, n. 198, São Paulo, out/dez 1994.

RESEK, Francisco / Fernando de Castro Fontainha et al. (orgs.). História oral do Supremo (1988-2013), v.15: Eros Grau. Rio de Janeiro: Escola de Direito do Rio de Janeiro da Fundação Getulio Vargas, 2016.

FONTANA, David. Docket Control and the Success of Constitutional Courts. Comparative Constitutional Law, Tom Ginsburg and Rosalind Dixon, eds., Edward Elgar Publishing, 2011; GWU Law School Public Law Research Paper. Disponível em: <http://ssrn.com/abstract=2256946>. Acesso em: 05 jun. 2016.

FRIEDMAN, Barry. The Politics of Judicial Review. Texas Law Review, v. 84, p. 257, 2005. Disponível em: <http://ssrn.com/abstract=877328>. Acesso em: 06 jun. 2016. 
FUX, Luiz; FONTAINHA, Fernando de Castro; MATTOS, Marco Aurélio Vannucchi Leme de; NUÑEZ, Izabel Saenger (orgs.). História Oral do Supremo [1988-2013], v. 12: Luiz Fux. Rio de Janeiro: Escola de Direito do Rio de Janeiro da Fundação Getúlio Vargas, 2016.

FUX, Luiz; FRAZÃO, Carlos Eduardo. O Supremo Tribunal Federal na fronteira entre direito e a política: alguns parâmetros de atuação. In SARMENTO, Daniel (coord.). Jurisdição Constitucional e Política. Rio de Janeiro: Forense, 2015.

GARAPON, Antoine. O juiz e a democracia: O guardião das promessas. $2^{\mathrm{a}}$ ed. Rio de Janeiro: Revan, 2001.

GARAVITO, César Rodríguez. O impacto do novo constitucionalismo: os efeitos dos casos sobre direitos sociais na América Latina. In BALDI, César Augusto (coord.). Aprender desde o Sul: novas constitucionalidades, pluralismo jurídico e plurinacionalidade aprendendo desde o Sul. Belo Horizonte: Editora Fórum, 2015.

GARGARELLA, Roberto; COURTIS, Christian. El nuevo constitucionalismo latinoamericano: promesas e interrogantes. CEPALsérie políticas sociales, n. 153, nov. 2009.

GARGARELLA, Roberto. India 8: Derechos Sociales: el momento reaccionario. In: Seminario de Teoria Constitucional y Filosofía

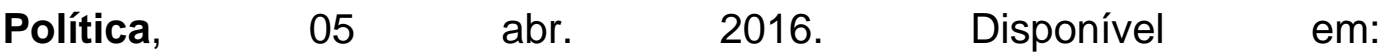
<http://seminariogargarella.blogspot.com.br/search?updated-max=201604-12T08:18:00-03:00\&max-results=25>. Acesso em: 03 jun. 2016.

. La sala de máquinas de la Constitución: dos siglos de constitucionalismo em América Latina (1810-2010). Buenos Aires: Katz Editores, 2014.

GAROUPA, Nuno. Constitutional Review. Texas A\&M University School of Law, mar. 2016. Disponível em: <https://economix.fr/pdf/workshops/2016_3rd_law_eco/NGaroupa.pdf>. Acesso em: 10 jul. 2016. 
SUPREMO TRIBUNAL FEDERAL. Julgamentos Históricos. Disponível em:<http://www.stf.jus.br/portal/cms/verTexto.asp?servico=sobreStfConhe caStfJulgamentoHistorico\&pagina=STFPaginaPrincipal4>. Acesso em: 18 jul. 2016.

GRAU, Eros; FONTAINHA, Fernando de Castro; MAFEI, Rafael; e ACCA, Thiago dos Santos (orgs.). História Oral do Supremo (1988-2003), v. 10: Eros Grau. Rio de Janeiro: Escola de Direito da Fundação Getúlio Vargas, 2015.

HARTMANN, Ivar. Com regras discutíveis, Supremo Tribunal Federal ganha projeção. Folha de São Paulo, São Paulo, 03 abr. 2016. Disponível em: <http://www1.folha.uol.com.br/ilustrissima/2016/04/1756464-com-regrasdiscutiveis-supremo-tribunal-federal-ganha-projecao.shtml>. Acesso em: 15 jul. 2016.

HOLANDA, Sérgio Buarque de. Raízes do Brasil. $8^{a}$ ed. Rio de Janeiro: Livraria José Olympio Editora, 1975.

JOBIM, Nelson; FONTAINHA, Fernando de Castro; PAULA, et. al. (orgs.). História Oral do Supremo [1988-2013], v. 9: Nelson Jobim. Rio de Janeiro: Escola de Direito do Rio de Janeiro da Fundação Getúlio Vargas, 2015.

KOATZ, Rafael Lorenzo-Fernandes. Deliberação e procedimento no STF: Discutindo a relação. Tese de doutorado (Departamento de Direito). Universidade do Estado do Rio de Janeiro. Rio de Janeiro, 2015.

KOERNER, Andrei. Judiciário e democracia na constituição da república brasileira. São Paulo: Hucitec/Departamento de Ciência Política, USP, 1998.

A análise política do direito, do Judiciário e da doutrina jurídica. In: WANG, Daniel Wei Liang. Constituição e política na democracia: aproximações entre direito e ciência política. 2013.

LASSALLE, Ferdinand. A essência da Constituição. $4^{\text {a }}$ ed. Rio de Janeiro: Lumen Juris, 1998. 
LEAL, Fernando Ângelo. Uma jurisprudência que serve para tudo. JOTA, São Paulo, 13 mai. 2015. Disponível em: <http://jota.uol.com.br/umajurisprudencia-que-serve-para-tudo>. Acesso em: 04 out. 2016.

. Até que ponto é possível legitimar a jurisdição constitucional pela racionalidade? Uma reconstrução crítica de "a razão sem voto"? In VIEIRA, Oscar Vilhena; GLEZER, Rubens (org.). A razão e o voto: diálogos constitucionais com Luís Roberto Barroso. Mimeografado. 2017.

LEITE, Fábio Carvalho. 1891: A Construção da Matriz PolíticoInstitucional da República no Brasil. Dissertação de Mestrado (Departamento de Direito). Pontifícia Universidade Católica do Rio de Janeiro. Rio de Janeiro, 2003.

LEITE, Fábio Carvalho; BRANDO, Marcelo. Dispersão de Fundamentos no Supremo Tribunal Federal. Direito, Estado e Sociedade, n. 48, p.139166, jan/jun 2016.

LESSA, Renato. A invenção republicana. Rio de Janeiro: Edições Vértice/IUPERJ, 1988.

. In: PILATTI, Adriano. A Constituinte de 1987-1988: progressistas, conservadores, ordem econômica e regras do jogo. Rio de Janeiro: Lumen Juris, Editora PUC-Rio, 2008.

LUGO, Carlos Rivera. La normatividade societal de lo común. In: RAJLAND, Beatriz; BENENTE, Mauro (coord). El Derecho y el Estado: processos políticos y constituyentes em nuestra América. Buenos Aires: CLASCO, 2016.

MASCARO, Alysson Leandro. Crítica da legalidade e do direito brasileiro. 2a ed. São Paulo: Quartier Latin, 2008.

- Crise brasileira e direito. Margem Esquerda: ensaios marxistas. São Paulo, n. 25, out. 2015.

MACIEL, Débora Alves; KOERNER, Andrei. Sentidos da judicialização da política: duas análises. Lua Nova, n. 57, 2002. 
MACHADO, Joana de Souza. Ativismo Judicial no Supremo Tribunal Federal. Dissertação de mestrado (Departamento de Direito). Pontifícia Universidade Católica do Rio de Janeiro. Rio de Janeiro, 2008. . Luz, câmera, jurisdição: tecnologia de comunicação e o mito da justiça transparente no Brasil. Boletim Cedes. Rio de Janeiro, jul-set. 2013.

MADISON, James; HAMILTON, Alexander; JAY, John. Os artigos federalistas, 1787-1788. Rio de Janeiro: Nova Fronteira, 1993.

MAUS, Ingeborg. Judiciário como superego da sociedade. Novos Estudos, São Paulo, n. 58, nov. 2000.

MEDINA, Damares; ALMEIDA, Eloísa Machado de. A incomum decisão liminar de Gilmar Mendes. Nexo Jornal, São Paulo, 19 mar. 2016. Disponível em: <https://www.nexojornal.com.br/ensaio/2016/A-incomumdecis\%C3\%A3o-liminar-de-Gilmar-Mendes>. Acesso em: 03 jun. 2016.

MELO, Daniela Mendonça. Judicialização da política e democracia no Brasil: do (des)governo do Judiciário. Juiz de Fora: Templo, 2012.

MENDES, Conrado Hübner. Controle de constitucionalidade e democracia. Rio de Janeiro: Elsevier, 2008a.

- Direitos Fundamentais, separação de poderes e deliberação. Tese de Doutorado (Departamento de Ciência Política). Faculdade de Filosofia, Letras e Ciências Humanas da Universidade de São Paulo. São Paulo, 2008b.

. Diálogo Institucional. Sociedade Brasileira de Direito Público.

Disponível

em: <http://www.sbdp.org.br/observatorio_ver.php?idConteudo=12>. Acesso em: 17 mai. 2017. 2008c.

. Is it All About the Last Word? Deliberative Separation of Powers. Legisprudence, v. 3, n. 1, p. 69-110, 2009a.

Onze Ilhas. Folha de São Paulo, São Paulo, 1 fev. 2010. 
<http://www1.folha.uol.com.br/fsp/opiniao/fz0102201008.htm>. Acesso em: 12 jul. 2016.

. O projeto de uma corte deliberativa. In: VOJVODIC, Adriana et al (Orgs.), Jurisdição Constitucional no Brasil. São Paulo: Malheiros, 2012.

A ingovernabilidade do STF. JOTA, São Paulo, 17 set. 2014.

Disponível em: <https://jota.info/artigos/materias19-a-ingovernabilidadedo-stf-17092014>. Acesso em: 23 mai. 2017.

MÉNDEZ, Juan E.; O'DONNELL, Guillermo; PINHEIRO, Paulo Sérgio. Democracia, Violência e Injustiça: o não-estado de direito da América Latina. São Paulo: Paz e Terra, 2000.

MENDONÇA, Eduardo. A Constitucionalização da política: entre o inevitável e o excessivo. Revista da Faculdade de Direito da UERJ, v. 18, 2010.

A jurisdição constitucional como canal de processamento do autogoverno democrático. In SARMENTO, Daniel (coord.). Jurisdição Constitucional e Política. Rio de Janeiro: Forense, 2015.

NETO, Cláudio Pereira de Souza. Jurisdição Constitucional, Democracia e Racionalidade Prática. Rio de Janeiro: Renovar, 2002.

NETO, Cláudio Pereira de Souza; SARMENTO, Daniel. Controle de Constitucionalidade e Democracia: algumas teorias e parâmetros de ativismo. In SARMENTO, Daniel (coord.). Jurisdição Constitucional e Política. Rio de Janeiro: Forense, 2015.

NETTO, Fernando Gama de Miranda; CAMARGO, Margarida Maria Lacombe. Representação argumentativa: fator retórico ou mecanismo de legitimação da atuação do Supremo Tribunal Federal? Anais do XIX Encontro Nacional do CONPEDI, Fortaleza, p. 1345-1354, jul. 2008.

PELLUZO, Cézar; FONTAINHA, Fernando de Castro et al. (orgs.). História Oral do Supremo [1988-2013], v. 4: Cézar Pelluso. Rio de Janeiro: Escola de Direito do Rio de Janeiro da Fundação Getúlio Vargas, 2015 
PILATTI, Adriano. Golpes e Constituições os caminhos e descaminhos da formação constitucional do Brasil desde o período colonial. In: GOMES, Marcos Emílio (Org.). A Constituição de 1988, 25 anos: a construção da democracia e liberdade de expressão: o Brasil antes e depois da Constituinte. $1^{\mathrm{a}}$ ed. São Paulo: Instituto Vladimir Herzog, p. 26-133, 2013. RODRIGUEZ, José Rodrigo. Fuga do direito. São Paulo: Saraiva, 2009. Como decidem as cortes? Para uma crítica do direito (brasileiro). Rio de Janeiro: Editora FGV, 2013.

RODRIGUES, Leda. História do Supremo Tribunal Federal: defesa das liberdades civis. Tomo 1/1891-1989. 2a ed. Rio de Janeiro: Civilização Brasileira, 1991.

História do Supremo Tribunal Federal. Tomo IV - Volume I/1930-1963. Rio de Janeiro: Civilização Brasileira, 2002.

- História do Supremo Tribunal Federal: defesa do federalismo. Tomo II/1899-1910. Rio de Janeiro: Civilização Brasileira, 1968.

SANTOS, Ricardo Augusto dos Santos. Transição Democrática Conservadora. Condições de Vida, Violência e Políticas de Saúde (19461950). Herramienta debate y crítica marxista. Disponível em: $<$ http://www.herramienta.com.ar/coloquios-y-seminarios/transicaodemocratica-conservadora-condicoes-de-vida-violencia-e-politicas-de>. Acesso em: 23 mai. 2017.

SCHWARZ, Roberto. As Ideias Fora de Lugar: ensaios selecionados. São Paulo: Companhia das Letras, 2014.

SILVA, Evandro Lins e. O salão dos passos perdidos: depoimento ao CPDOC. Rio de Janeiro: Nova Fronteira, Editora FGV, 1997.

SILVA, Virgílio Afonso da. O STF e o controle de constitucionalidade: deliberação, diálogo e razão pública. Revista de Direito Administrativo, v. 250, p. 197-227, ago. 2012. Disponível em: <http://bibliotecadigital.fgv.br/ojs/index.php/rda/article/view/4144/2927>. Acesso em: 17 mai. 2017. 
. Deciding without deliberating. Internacional Jnl of

Constitucional Law, Oxford, v. 11, Issue 3, p .557-584, 2013.

. Um voto qualquer? O papel do ministro relator na deliberação

no Supremo Tribunal Federal. Revista Estudos Institucionais, v. 1, 1, 2015.

. O relator dá a voz ao STF? Uma répllica à Almeida e Bogossian. Revista Estudos Institucionais, v. 2, 2, 2016.

SOUZA, Jessé. A Tolice da inteligência brasileira: ou como o país de deixa manipular pela elite. São Paulo: LeYa, 2015.

SOUZA, Luiz Henrique Boselli de. A doutrina brasileira do habeas corpus e a origem do mandado de segurança Análise doutrinária de anais do Senado e da jurisprudência histórica do Supremo Tribunal Federal. Revista do Senado, a. 45, n. 177, jan/mar 2008. Disponível em: < https://www2.senado.leg.br/bdsf/bitstream/handle/id/160190/Doutrina_hab beas_corpus_177.pdf?sequence=7>. Acesso em: 10 jul. 2016.

STRECK, Lênio Luiz. Jurisdição Constitucional e Hermenêutica: Uma Nova Crítica do Direito. $2^{\mathrm{a}}$ ed. Rio de Janeiro: Forense, 2004.

SUNDFELD, Ari; PINTO, Henrique Motta. Três Desafios para Melhorar a Jurisdição Constitucional Brasileira. In VOJVODIC, Adriana; PINTO, Henrique Motta et al. (Org.), Jurisdição Constitucional. São Paulo: Malheiros, 2012.

TAYLOR, Matthew. O Judiciário e as políticas públicas no Brasil. Dados Revista de Ciências Sociais, v. 50, n. 2, pp.229-257, 2007.

. Os partidos dentre e fora do poder:a judicialização como resultado contingente da estratégia política. Dados - Revista de Ciências Sociais, Rio de Janeiro, v. 51, n. 4, p. 825-864, 2008.

Judging Policy: courts and policy reform in democratic Brazil. Califórnia: Stanford University Press, 2008.

VALE, Oswaldo Trigueiro do. O Supremo Tribunal Federal e a instabilidade político institucional. Rio de Janeiro: Civilização Brasileira, 1976. 
VIANNA, Oliveira. O idealismo da Constituição. Rio de Janeiro: Terra de Sol, 1927.

VELLOSO, Carlos; FONTAINHA, Fernando de Castro et al. (orgs.). História Oral do Supremo [1988-2013], v. 7: Carlos Velloso. Rio de Janeiro: Escola de Direito do Rio de Janeiro da Fundação Getúlio Vargas, 2015.

VERÍSSIMO, Marcos Paulo. A constituição de 1988, vinte anos depois: suprema corte e ativismo judicial "à brasileira". Revista Direito GV, v. 4, n. 2, 2008.

. Controle de constitucionalidade e ativismo judicial. In: WANG, Daniel Wei Liang. Constituição e política na democracia: aproximações entre direito e ciência política. São Paulo: Marcial Pons, 2013.

VILLEGAS, Mauricio García. Constitucionalismo aspiracional: derecho, democracia y cambio social em América Latina. In BALDI, César Augusto (coord.). Aprender desde o Sul: novas constitucionalidades, pluralismo jurídico e plurinacionalidade - aprendendo desde o Sul. Belo Horizonte: Editora Fórum, 2015.

VARGAS, Daniel. Ministros do STF arriscam jogar nitroglicerina na disputa política. Carta Capital, São Paulo, 2 mai. 2016. Disponível <http://www.cartacapital.com.br/politica/ministros-do-stf-arriscam-jogarnitroglicerina-na-disputa-politica>. Acesso em: 03 jun. 2016.

VERONESE, Alexandre. A judicialização da política na América Latina: panorama do debate teórico contemporâneo. Escrito: Revista da Fundação Casa Rui Barbosa, ano 3, n. 3, 2009. Disponível em: <http://www.casaruibarbosa.gov.br/escritos/numero03/artigo13.php>.

Acesso em: 15 mai. 2017.

VIANNA, Luiz Werneck et al. A Judicialização da Política e das Relações Sociais no Brasil. $2^{\mathrm{a}}$ ed. Rio de Janeiro: Revan, 2014.

VILHENA, Oscar. A Constituição como reserva de justiça. Lua Nova, São Paulo, n. 42, 1997. 
. Mais uma vez, STF é convocado a desempenhar papel chave. Folha de São Paulo, São, Paulo, 19 mar. 2016. Disponível em: <http://www1.folha.uol.com.br/colunas/oscarvilhenavieira/2016/03/175175 6-a-chave.shtml>. Acesso em: 15 mai. 2017.

. Supremocracia. Revista Direito GV. São Paulo, n. 4, p. 441464, jul-dez 2008.

VOJVODIC, Adriana de Moraes; MACHADO, Ana Mara França; CARDOSO, Evorah Lusci Costa. Escrevendo um romance, primeiro capítulo: Precedentes e processo decisório no STF. Revista Direito GV, n. 21, jan-jun. 2009.

WALDRON, Jeremy. O judicial review e as condições da democracia. In: BIGONHA, Antonio Carlos Alpino; MOREIRA, Luiz (org.). Legitimidade da jurisdição constitucional. Rio de Janeiro: Lumen Juris, 2010.

WOLKMER, Antonio Carlos. Constitucionalismo e pluralismo na trajetória do direito brasileiro. In BALDI, César Augusto (coord.). Aprender desde o Sul: novas constitucionalidades, pluralismo jurídico e plurinacionalidade aprendendo desde o Sul. Belo Horizonte: Editora Fórum, 2015. 